\title{
PRINCIPLE \& PRAGMATISM: \\ The New Zealand Fair Trade consumer and their perspectives on the future of Fair Trade
}

\author{
William Watterson \\ School of Earth Sciences \\ Victoria University of Wellington \\ Wellington, Aotearoa New Zealand \\ Submitted in partial fulfillment of the \\ Master of Development Studies (MDS) Degree
}

April 2008 


\section{Abstract}

Using exploratory, qualitative focus groups, this thesis investigates the perspectives, motivations and concerns of a specific group of dedicated New Zealand Fair Trade consumers, the reasons surrounding their willingness to pay an ethical premium, and the ways they learn about Fair Trade products. It also explores the complex interrelationship between their ethical beliefs and purchase behavior, and their perspectives on the future of the Fair Trade movement.

The research contributes to the growth of ethical and Fair Trade consumerism, thereby linking the development of sustainable livelihoods in the North to development and export opportunities for small-scale producers in the South. The findings of this study could have important implications for the development of sensitized marketing strategies and more effective consumer education campaigns directed at this increasingly significant segment. It could also help translate the ideas and concerns of Fair Trade consumer into opportunities for Fair Trade organizations and developing country producers.

The responses of Fair Trade consumers are sorted into themes, which are then discussed in the subsequent chapters. The final chapter pulls these analyses together to form a final set of conclusions, the implications of those conclusions on international development, and my subsequent recommendations.

The findings of this research indicate that New Zealand Fair Trade consumers are people of principle and pragmatism who are committed to both ethical ideals and practical development results. They are concerned about environmental issues and the tension between consumption and sustainability, and also about the co-option of the Fair Trade 'image' by mainstream business as a method of corporate greenwashing. Participants' testimonies indicate that Fair Trade provides a way of reducing 
social distance between consumers in the north and producers in the south. It is also a useful tool for promoting and developing global citizenship among northern consumers. The participants generally do not regard Fairtrade labeling as a long-term solution but rather a necessary interim 'band-aid' that can both support modest development in the south whilst educating northern consumers on the wider injustices in world trade. They also suggest that Fair Trade could more effectively catalyze this transformation of northern consumer to 'global citizen' by using marketing as a tool for consumer education.

The thesis makes recommendations concerning the implementation of more strategic Fair Trade marketing campaigns and branding efforts, as well as the need to explore deeper ways of storytelling across all aspects of Fair Trade media in order to further engage northern consumers. It highlights the importance of maintaining a tension in the Fair Trade movement between unwavering commitment to ethical principles on one hand, and flexibility and a willingness to adapt to changing world circumstances and consumer/producer needs on the other. It also recommends that Fair Trade organisations remain in dialogue with other ethical movements like sustainability in order to better understand and address these needs. 


\section{Acknowledgements}

There are a number of people and organisations I would like to thank for their involvement in this research:

Chris Marshall and Richard Willis: for your help in the early stages of my topic selection. Your time was very much appreciated.

John Overton: For being a patient and understanding supervisor, and always remaining positive and optimistic even when things seemed unpromising.

Friends, family and my church community: For moral, emotional and even financial support during this very long haul!

My son Asher: For giving me the most reason to persevere with this daunting project.

The participants: For your honesty, creativity and commitment to the research! Thank-you! 


\section{Contents}

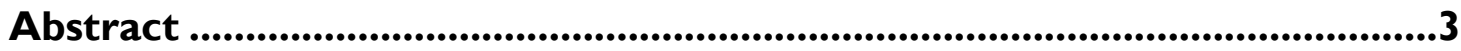

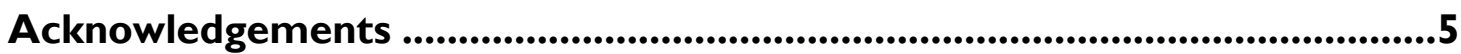

Chapter I: Introduction to the Literature ............................................................7

Fair Trade - then and now ................................................................................................

Trade in a Development Context .................................................................................. 7

The Emergence of Fair Trade ......................................................................................... 10

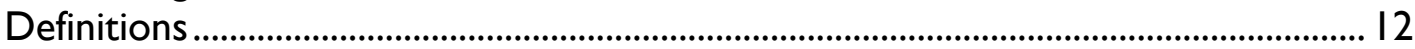

Market Characteristics .......................................................................................... 13

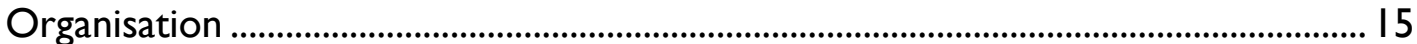

Ethical Consumption ..................................................................................................... 19

The Fair Trade consumer ........................................................................................... 19

Chapter 2: The Research ......................................................................................22

Rationale for this Thesis ......................................................................................... 22

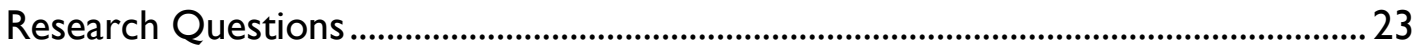

Projected Implications for Development ........................................................................ 23

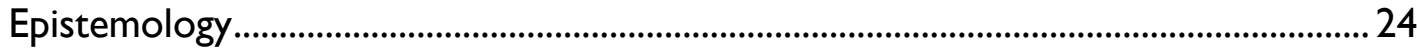

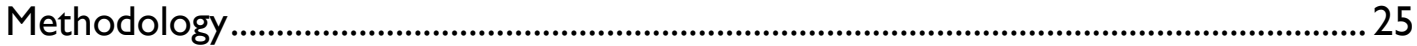

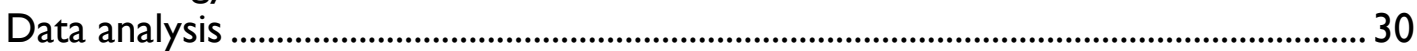

Structure of this research paper ..................................................................................... 32

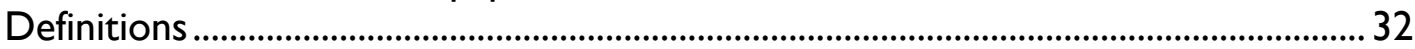

Chapter 3: People of Principle ...................................................................34

Chapter 4: Social Distance..............................................................................40

Chapter 5: Environmental Concerns .........................................................................46

Chapter 6: From Ethical Consumption to Global Citizenship ........................56

Chapter 7: Corporate Co-option and Green-washing .......................................66

Chapter 8: Band-aids and Brain Surgery .................................................................7 I

Chapter 9: Advertise and Proselytise ...................................................................79

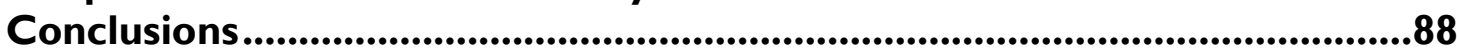

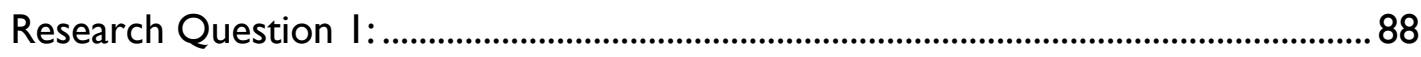

Research Question 2: .............................................................................................. 90

Recommendations and Implications for Development....................................92

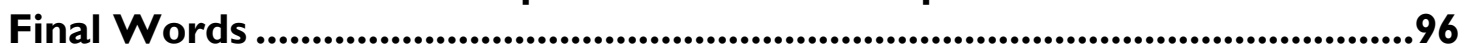

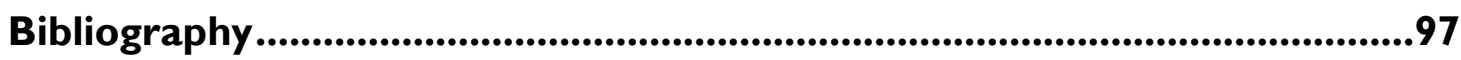

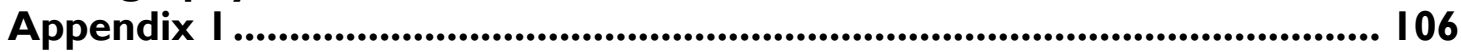

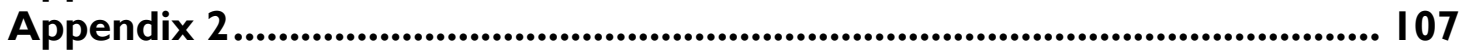

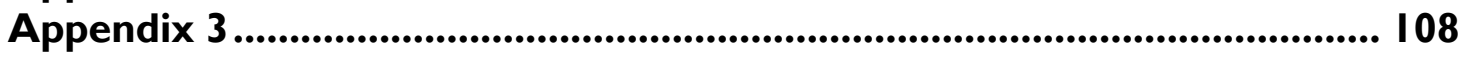

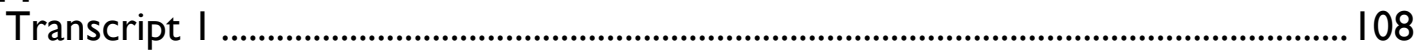

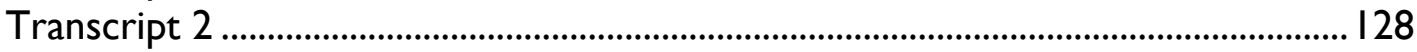




\section{Chapter I: Introduction to the Literature}

\section{Fair Trade - then and now}

\section{Trade in a Development Context}

The Fair Trade concept is based on the idea that paying third world producers a fair price for their products can provide a more efficient way of encouraging sustainable development in developing countries than aid, which often creates dependency and pacification. The concept is rooted in the belief that existing world trade practices are a major cause of underdevelopment and the unjust distribution of wealth among nations, as well as adding to worldwide environmental degradation and compromising food security. Fair trade attempts to accommodate the social problems originating from the global emphasis on 'Free', rather than 'Fair', trade and the steady ambition of integrating developing countries into market economy despite the social and environmental consequences.

Free Trade theory holds that the ideal Market model is one where trade in goods and services between or within countries flows unhindered by government-imposed restrictions (Vander, 2005). Such restrictions include taxes and tariffs, and other nontariff barriers, such as legislation and quotas. Trade liberalization entails reductions to these trade barriers. Though sound in theory, there is a problem with the way this system is currently operated in today's global trading arena. As Oxfam (2002, p.7) eloquently puts it,

\footnotetext{
"There is a paradox at the heart of international trade. In the globalised world of the early twentieth century, trade is one of the most powerful forces linking our lives. It is also the source of unprecedented wealth. Yet millions of the world's poorest people are being left behind. Increased prosperity has gone hand in hand
} 
with mass poverty and the widening of already obscene inequalities between rich and poor. World trade has the potential to act as a powerful motor for the reduction of poverty, as well as for economic growth, but that potential is being lost."

The problem lies not in the theory of Free Trade, but in its current application. Under the current system, for instance, low-income developing countries account for more that 40 per cent of the world population, but less than 3 per cent of world trade (Oxfam, 2002, p710). There are currently I.I Billion people struggling to survive on less than one dollar a day - the same as the mid-1980's (ibid). Developing countries that seek to better this situation by exporting to rich-country markets face tariff-barriers that are four times higher than those encountered by rich countries (ibid). At the same time, industrialized-country governments subsidize their domestic farmers more than \$I billion a day, causing massive over-production, driving down prices for exports from developing countries and devastating the prospects for smallholder agriculture (ibid). These, and other, trade restrictions cost developing countries $\$ 100$ billion a year - twice as much as they receive in aid (ibid). Because of this 'uneven' playing field on which the Free Trade 'game' takes place, only 33 countries managed to sustain 3 percent annual growth during 1980-96. For 59 countries (mainly in Sub-Saharan Africa and Eastern Europe and the CIS) GNP per capita declined (UNDP, 1999, p.3I).

There is now overwhelming evidence to prove that when trade liberalisation is imposed upon countries that are not ready or able to cope, it can contribute to a vicious cycle of financial instability, debt and recession (Khor, 2000). Khor encapsulates the problem well:

"The problem in trade liberalisation is that a country can control how fast to liberalise its imports (and thus increase the inflow of products) but cannot determine by itself how fast its exports grow. Export growth partly depends on the prices of the existing 
exported products (and developing countries have suffered from serious declines in their terms of trade) and also on having or developing the infrastructure, human and enterprise capacity for new

exports (which is a long-term process and not easily achieved). It also depends on whether there is market access especially in developed countries." (ibid, p.2)

As Khor alludes to, key conditions on which Free Trade theory is based are notably absent in many developing countries, especially in rural agricultural societies. Perfect market information, perfect access to markets, access to credit, and an ability to switch production techniques and outputs in response to market information are fundamental assumptions in the Free Trade model which are fallacious in the context of agricultural producers and workers in many developing countries. Both agricultural and industrial producers in the South also face massive tariff and non-tariff barriers in Northern countries. Meanwhile, these same Northern countries demand that the South reduce their own trade barriers in order to allow the North's cheap subsidized products to flood their markets, devastating small farmers' and domestic businesses' ability to compete and adding to unemployment and poverty. In a sense, the current state of the international trading system presents an uneven playing field, where certain players (developing countries) are not equipped properly to participate effectively and reap the same benefits as other players. Most developing countries depend on the export of raw materials for survival and development. The prices of imported capital have been going up, while the world market prices for primary products have been systematically decreasing in relative terms. One reason for this is the standard-lowering related to Free Trade (Daly 1993, p. I48). This has also been the tendency of the coffee market, with grave consequences for the smallscale farmers in particular. These are generally uneducated, unaware of the market conditions and heavily underpaid with a constant liquidity problem. Therefore, the majority of their profits end up in the hands of the middlemen, who are able to pay the farmers in cash and know the way the market works. 


\section{The Emergence of Fair Trade}

Young (2003, p.I) describes Fair Trade as having "an honourable past, having played a major part in raising awareness about corporate responsibility issues and building capacity in large numbers of poor producer organisations in the less developed world." Working "in and against" the market (Raynolds, 2000, p.299), Fair Trade emerged as both a practical and political reaction to the rise of Free Trade, capitalism and the power of the Trans-national Corporation. The Fair Trade organisations grew from the acknowledgement that paying developing country producers a fair and consistent price for their goods could help to correct some of the inequalities in the current trading system.

Though Fair Trade has had many players in its brief history, it can be traced back to efforts made by US churches to sell handicrafts made by refugees in Europe after World War II (Moore, 2004). The groups involved were known as Alternative Trading Organisations (ATOs) a name stemming from the early days of Fair Trade where "fair" seemed too weak a description of the vision that these companies had. In comparison to conventional trading structures, ATOs offered higher returns to producers in the developing world through direct trade and fair prices. The Mennonite Central Committee (MCC) and SERRV International were the first, in 1946 and 1949 respectively, to develop such supply chains with developing countries (Hiscox, 2007). The products, almost exclusively handicrafts ranging from jute goods to cross-stitch work, were mostly sold by volunteers in 'charity stores' or 'ethnic shops'. The goods themselves had often no other function than to indicate that a donation had been made (ibid). In 1965, Oxfam started their 'Helping-by-Selling' project - arguably the forerunner of what is now called Fair Trade (ibid). As well as offering fairer prices to craft producers, the project also helped those producers to make and market their products to Western countries. 
From those early efforts of Oxfam and the ATO's, Fair Trade began to expand and coalesce as a 'movement' in the 1960s and 1970s. In 1988, overproduction caused world coffee prices to sharply decline, triggering the birth of the first Fair Trade certification initiative. It was branded "Max Havelaar," after a fictional Dutch character who opposed the exploitation of coffee pickers in Dutch colonies. The Netherland's Max Havelaar label offered mainstream coffee industry players the opportunity to adopt a standardized system of Fair Trade criteria. The initiative pursued tight and binding co-operation between all links in the value chain, excluding middlemen wherever possible, with an emphasis on long-term contracts between producers and roasters (Langland, 1998). The farmers formed or joined cooperatives based on principles of equality and democracy, which both strengthened their negotiating position and enabled them to undertake various value-adding functions--such as washing and grading their coffee. In return, the farmers agreed to embrace more sustainable farming practices, with the eventual goal of growing crops according to organic principles. In practice, the agreement was financed partly through an increased consumer price of approximately $25 \%$ and partly by excluding the middlemen and their (often extensive) profits. The Fair Trade system was thus sustained by those consumers willing to pay a surplus for commodities with an added value of environmental, ethical or social appeal.

Since then, "alternative trade", or Fair Trade organizations like Equal Exchange, SERRV International, and Ten Thousand Villages, have sought to address structural inequities in the global economy and promote grassroots development through direct, equitable trade. Many ATOs are members of the Fair Trade Federation, an association of Fair Trade wholesalers, retailers, and producers whose members are committed to providing fair wages and employment opportunities to economicallydisadvantaged artisans and farmers worldwide. In 1997, FLO, the international umbrella organization for Fair Trade labeling, brought Max Havelaar together with its counterparts in other countries. The FLO organizations conduct inspections of producers in developing countries, examine their contracts with buyers, and monitor the chain of custody by which the goods are supplied to retailers in developed 
country markets. Retailers are licensed to use the "Fairtrade" (or "Fair Trade Certified”) trademark only when all the FLO when standards have been met.

As a movement started to combat the negative effects of Free Trade, Fair Trade has become a dynamic and successful dimension of an emerging counter-tendency to the neo-liberal globalisation regime. "[l]n general Fair Trade has remained a practical and campaigning response to the perceived and observed injustices of the capitalist system." (Moore 2004, p.6)

\section{Definitions}

Over its history there have been many and varied definitions of Fair Trade. However, in an attempt to produce a widely accepted definition, an informal association of four main Fair Trade networks called FINE was created in 1998. FINE developed the following definition:

Fair Trade is a trading partnership, based on dialogue, transparency and respect, that seeks greater equity in international trade. It contributes to sustainable development by offering better trading conditions to, and securing the rights of, marginalized producers and workers - especially in the South. Fair trade organisations (backed by consumers) are engaged actively in supporting producers, awareness raising and in campaigning for changes in the rules and practice of conventional international trade. (FINE, 200I, cited in Wilkinson, 2006, p.5)

The goals of Fair Trade that flow from this definition are: 
To improve the livelihoods and well-being of producers by improving market access, strengthening producer organisations, paying a better price and providing continuity in the trading relationship.

To promote development opportunities for disadvantaged producers, especially women and indigenous people, and to protect children from exploitation in the production process.

To raise awareness among consumers of the negative effects on producers of international trade so that they exercise their purchasing power positively.

To set an example of partnership in trade through dialogue, transparency and respect.

To campaign for changes in the rules and practice of conventional international trade.

To protect human rights by promoting social justice, sound environmental practices and economic security.

(Redfern \& Snedker, 2002, p.II)

\section{Market Characteristics}

Fair Trade was born out of business strategy as much as it was born out of politics. One of the initial goals of Fair Trade was to enable producers to "become sustainable businesses in the local, regional and international marketplaces" (Littrell \& Dickson, 1998, p. (8I). It is therefore not surprising that the dominant model of Fair Trade from its inception has been has been the parallel or alternative supply chain approach 
(see Appendix I). This re-engineering of the supply chain is a key principle of Fair Trade. The process is similar to a normal supply-chain model of business, in that there are producers, importers, processors, retailers and consumers. The difference is the monitoring and certification at the core of the system which guarantees that the supply chain is built on, and functions according to, standards of fairness, transparency and accountability. Fair Trade retailers and wholesalers typically work directly with artisans and farmers, cutting out the middle men who increase the price at each level - enabling retail products to remain competitively priced in respect to their conventional counterparts, while fairly compensating producers.

While it is not easy to measure precisely, Fair Trade sales worldwide are now believed to have crossed the $\$$ I Billion mark (Myers, 2007, p.I), with some researchers putting the figure closer to $\$ 1.5$ billion for both labeled and unlabeled products (Hiscox, 2007, p.5). There are over 6 million people (producers and their dependents) benefiting from Fair Trade, supported by 667 FLO registered traders worldwide (ibid, p.22). Though Fair Trade still only accounts for $1 \%$ of the global market, it has grown rapidly from very humble beginnings, with an average of $20 \%$ growth per year since the year 2000 (ibid). Sales of Fairtrade products in Europe, North America, and Japan have grown exponentially in recent years; Fairtrade bananas have a 50 per cent market share in Switzerland (AgroFair, 2004). Fairtrade coffee is the fastest-growing segment of the speciality coffee industry in the US and UK (McCarthy, 2004). The UK market in 2004 was worth about $£ \mid 30 \mathrm{~m}$. To date, these figures include the initially small, but rapidly growing, US market. If US market development follows the pattern of European markets - and there is evidence to believe that it may be moving even faster - global sales of Fairtrade will increase by a factor of 10-15 in the next few years (Demetriou, 2003).

In Australia and New Zealand, estimated retail sales of Fair Trade products have risen from $\$ 200 \mathrm{k}$ in 2003 to $\$ 10$ million in 2006 [FLANZ, 2006]. The FLANZ forecast for the 2005-06 financial year was wholesale sales of AU\$5m, yet recorded sales so far are $A \cup \$ 6.75 \mathrm{~m}$ ! The number of Licensees has increased from 7 at end of 2003, 26 at 
end 2004, 58 at end of 2005, to now almost 100. According to the same report, public awareness of the Fair Trade concept in New Zealand has increased from 24\% in 2005 to $37 \%$ in 2006, but with recognition of the label still low. Importers are forecasting Fairtrade imports of over 600 million tons in 2006 (ibid).

The recent growth of the Fair Trade market appears to be entwined with the burgeoning interest in "ethical" and "green" consumption, where consumers choose products which they believe are less harmful to themselves and the environment. Consumer trust in the mainstream food sector has been shattered in recent years by findings of high levels of chemical residues, the proliferation of pharmaceuticals like Bgh in milk and GMOs in grains, and outbreaks of 'mad cow' disease and E. Coli contamination (Raynolds, 2000). Fair Trade labels strive to reestablish consumer trust in the origins and content of their food, attesting that items have been produced outside the corporate agro-industrial system responsible for heightening the health and ecological risks associated with our food supplies. Many Fair Trade labeled food products are also organic, linking the growth of Fair Trade to the global boom in certified organic markets (ibid).

\section{Organisation}

The Fair Trade movement is made up such a variety of organisations and stakeholders that it can often confuse anyone new to the concept. However, all the actors in the Fair Trade movement can generally be divided into four main groups.

Firstly, there are the producer organisations in developing or Southern countries which supply the products. These are usually made up of small farmers who form or join co-operatives which are based on principles of equality and democracy. Not only do these co-operatives increase solidarity between local communities, but they are also responsible for deciding how to use the Fair Trade premium these communities receive as part of the Fair Trade relationship. 
Second, there are the buying organisations in developed or Northern countries which act as importers, wholesalers and retailers of the products purchased from the Southern producer organisations. In New Zealand the most prominent of these would be Trade Aid, as well as coffee roasteries like Peoples Coffee and Coffee Supreme.

Third, there are the umbrella bodies which consist of the following six organisations:

\begin{tabular}{|c|c|}
\hline $\begin{array}{l}\text { The International Fair } \\
\text { Trade Association (IFAT) }\end{array}$ & $\begin{array}{l}\text { Established in 1989. Is a worldwide membership } \\
\text { organisation that brings together both producers and } \\
\text { buyers. It consists of approximately I I } 0 \text { producer } \\
\text { organisations and } 50 \text { buying organisations, although } \\
\text { its membership is expanding (Website } 22 \text { ). }\end{array}$ \\
\hline $\begin{array}{l}\text { Fair Trade Labelling } \\
\text { Organisations } \\
\text { International (FLO) }\end{array}$ & $\begin{array}{l}\text { Established in I997. Is the worldwide Fair Trade } \\
\text { standard setting and certification organisation. "It } \\
\text { permits more than } 800,000 \text { producers and their } \\
\text { dependents in more than } 40 \text { countries to benefit } \\
\text { from labelled Fairtrade. FLO guarantees that } \\
\text { products sold anywhere in the world with a Fairtrade } \\
\text { label ... conform to Fairtrade Standards ..." } \\
\text { (Website } 23 \text { ). FLO currently sets standards for the } \\
\text { following products: bananas, cocoa, coffee, fresh fruit, } \\
\text { honey, juices, rice, sugar, tea and sports balls, with } \\
\text { standards for more tropical fruit, wines and other } \\
\text { tropical products under development. It also has two } \\
\text { sets of generic producer standards, one for small } \\
\text { farmers, which applies to smallholders organised in } \\
\text { co-operatives or other organisations with a } \\
\text { democratic, participative structure, and the other for } \\
\text { workers in plantations and factories. FLO estimates }\end{array}$ \\
\hline
\end{tabular}




\begin{tabular}{|c|c|}
\hline & $\begin{array}{l}\text { that, as of June 2003, it is working with } 3 \text { I } 5 \text { certified } \\
\text { producer organisations, representing almost } 500 \text { first } \\
\text { level producer structures, and around } 900,000 \\
\text { families of farmers and workers, coming from over } \\
40 \text { countries in Africa, Asia and Latin America (ibid); } \\
249 \text { registered traders, consisting of exporters, } \\
\text { importers, processors and manufacturers, coming } \\
\text { from over } 6 \text { I countries; and } 443 \text { licensees, } \\
\text { authorised by FLO's member organisations (the } \\
\text { National Initiatives which use labelling schemes such } \\
\text { as Fairtrade Mark in the U.K. and Ireland, Max } \\
\text { Havelaar (7 European countries), Transfair (4 } \\
\text { countries including the U.S. and Canada), Reilun } \\
\text { kauppa (Finland) and Rattvisemarkt (Sweden) (EFTA, } \\
200 I) \text { ). FLO has recently introduced a common label } \\
\text { to be applied across all products in all countries; } \\
\text { something that has both clear packaging and } \\
\text { marketing advantages. Unlike most certification } \\
\text { initiatives, the costs of FLO's annual monitoring and } \\
\text { certification are paid by Northern importers, not by } \\
\text { producers (Raynolds, } 2000 \text { ). }\end{array}$ \\
\hline $\begin{array}{l}\text { The Network of } \\
\text { European Worldshops } \\
\text { (NEWS!) }\end{array}$ & $\begin{array}{l}\text { Established in 1994, acts as the umbrella body for the } \\
\text { approximately } 2,700 \text { "world shops" that retail } \\
\text { predominantly Fair Trade goods across Europe } \\
\text { (EFTA, 200I, p. I0). }\end{array}$ \\
\hline $\begin{array}{l}\text { The European Fair Trade } \\
\text { Association (EFTA) }\end{array}$ & $\begin{array}{l}\text { Established in 1990, not to be confused with the } \\
\text { European Free Trade Association of the same } \\
\text { abbreviation. Is an association of } 12 \text { importing } \\
\text { organisations in } 9 \text { European countries (ibid, p. 10). }\end{array}$ \\
\hline Fair Trade Federation & Is an association of Fair Trade wholesalers, retailers \\
\hline
\end{tabular}




\begin{tabular}{|l|l|}
\hline & $\begin{array}{l}\text { and producers with } 84 \text { members in 2000, covering } \\
\text { the U.S. and Canada and promoting products which } \\
\text { bear the TransFair label (see above under FLO). }\end{array}$ \\
\hline Shared Interest & $\begin{array}{l}\text { While not a trade association organisation in the } \\
\text { same way as the other umbrella bodies with the } \\
\text { exception of FLO, Shared Interest provides trade } \\
\text { finance to the Fair Trade movement largely via a } \\
\text { "Clearing House" promoted jointly with IFAT but } \\
\text { also serving producers certified by FLO. }\end{array}$ \\
\hline
\end{tabular}

The various Fair Trade umbrella organisations now work together as FINE (an acronym of the initial letters of the organisations FLO, IFAT, NEWS and EFTA). They share information and when appropriate, they co-ordinate lobbying and awareness raising efforts.

Fourth, there are a wide range of mostly conventional organisations, typically supermarkets, that engage in some way in Fair Trade. As indicated above, 43,000 supermarkets across Europe and a further 7,000 in the U.S. and Canada stock Fair Trade products. While in one sense these could rightly be regarded as being outside the Fair Trade movement, they are becoming increasingly important players in the retailing of Fair Trade products, and as Fair Trade becomes more mainstream, this trend is likely to increase. Many of the supermarkets sell products sourced from the Fair Trade movement. However, a number are beginning to sell "own brand” Fair Trade products sourced directly from producers without involving the ATOs as middlemen. In the U.K. the Co-operative supermarket group is in the forefront of this development. New Zealand however is yet to see a significant presence of Fair Trade products in supermarkets. 


\section{Ethical Consumption}

Fair Trade taps the recent rise in 'ethical consumption', where consumers purchase items which they think have positive, or at least less negative, social implications.

Ethical consumption is widespread in Europe and social labels are increasingly being used to inform consumers that basic human rights have been maintained in international supply chains (Tiffen \& Zadek, 1998). The emergence of the ethical consumer has been much discussed, but evidence suggests that ethical consumption is more celebrated than practiced (Tallontire, 200I). Indeed, there appears to be a divergence between opinion polls on green and ethical consumer values, and the volume of sales of 'ethical' products. Much of the data on ethical consumption is in the form of quantitative market research and opinion polls. Some surveys have been undertaken to understand the ethical market in general and issues that consumers may relate to their purchasing habits, eg Shaw and Clarke (1999), Ayglon (1999), and MORI (1998).

Whilst these quantitative surveys may guide marketing strategies for companies selling products with ethical attributes, they are less effective than more qualitative methods at exploring the motivation of consumers. A more qualitative approach is needed if we are to explore the complexity of ethical beliefs and the subsequent effects that these beliefs have on purchase behavior.

\section{The Fair Trade consumer}

Whilst there has been a small but positive consumer response to fair-trade products and an increasing awareness of fair-trade labels, fair-trade organizations do not understand what motivates consumers to choose their products or the underlying meaning of fair-trade for consumers (Langland, 1998). 
Three quantitative surveys have been conducted specifically on the issue of Fair Trade consumerism (Tallontire, 200I):

Ayglon (1999) Oxfam Fair-trade Co. Aimed to understand what influences purchase behaviour in Oxfam shops: what is bought and how often and why.

MORI (January 1999) Fairtrade Foundation. Investigated consumer support for fair-trade.

NOP (1994) Christian Aid. Investigated awareness of fair-trade products and their availability.

These surveys reveal that regular fair-trade buyers are untypical of the population as a whole: they are better educated, wealthier, mostly female, over 30 years of age and tend to work in the public sector or 'caring professions'. Research into Oxfam fairtrade buyers revealed that they are generally: under 50 years of age, a Guardian newspaper reader, white/British, married, Labour supporting, undertaken further education (Oxfam Campaigns, 1995). Traidcraft research provides a similar profile: customers are also mainly female, $72 \%$ are over 35 , working professionals (mostly teachers and lecturers), $5 \mathrm{I} \%$ of which have household incomes in excess of $£ 20000$ (Traidcraft, 1996).

Beyond this, current knowledge on the Fair Trade consumer is patchy and largely dependent on commercial opinion polls (Tallontire 200I). Those promoting the consumption of ethical and Fair Trade products recognize the limitations of quantitative surveys, but because of relatively low levels of awareness of concepts such as fair-trade, they have been the only feasible option. When fair-trade was less well known, it was not realistic to get consumers together in focus groups to talk about their views of what fair-trade is about. However with the rapid growth of the Fair Trade market, Fair Trade researchers like Tallontire (200I) believe it may be far more feasible now. As Moore (2004, p.6) has suggested, "there is clearly work to be 
done in developing and articulating theoretical perspectives within which Fair Trade makes sense." Consequently, New Zealand Fair Trade consumers have some valuable perspectives of their own to offer to the Fair Trade debate. 


\section{Chapter 2: The Research}

\section{Rationale for this Thesis}

An increasing number of people make their consumption decisions on the basis of ethical values, such as environmentally friendly products and production methods, labour standards (wage rates and working conditions), and human rights. Ethical consumerism is a growing phenomenon that underpins these ethical trade activities (Tallontire, 200I).

There are many motivations for ethical business practice (for instance, the values of the people involved, the belief that ethical business practices, particularly environmental responsibility, will produce more effective and efficient results), but the apparent demand from 'ethical consumers' is key. Many businesses adopt ethical practices because this is what they believe the consumer wants. Indeed there is growing evidence that consumers are becoming more discerning as a result of changing tastes and expectations. One trend in particular has risen to popular attention in recent years - the phenomenon of the 'Fair Trade' market and the 'Fair Trade' consumer.

However, relatively little is known about the Fair Trade consumer. Moreover, there is little information about what makes Fair Trade consumers behave as they do. What makes them aware of trade issues and what motivates them to alter their consumption patterns to reflect their values?

A greater understanding of how consumers become aware of ethical issues in trade and the way in which they translate this into Fair trade purchase behavior is critical for developing strategies for raising the awareness of consumers in general. The attitudes and perspectives of consumers towards Fair Trade products are also the clearest demonstration of the impact of Fair Trade in the market (Tallontire, 200I), 
and could be a valuable litmus test in assessing the successes and failures of the Fair Trade movement so far.

\section{Research Questions}

I. What ethical beliefs are held by dedicated New Zealand Fair Trade consumers that influence their purchase behaviour?

2. Could these beliefs or perspectives translate into opportunities for Fair Trade organizations and developing country producers?

\section{Projected Implications for Development}

This study of Fair Trade consumer perspectives is expected to contribute to the wider field of International Development by:

I. Proposing refined methods of raising consumer awareness of the ethical issues surrounding trade and the concept of global citizenship

2. Supporting increased Fair Trade consumer activity

3. Translating Fair Trade consumer trends, beliefs and ideas into opportunities for Fair Trade organizations and developing country producers. 
For many agencies working with small-scale producers in developing countries, the growth of ethical and Fair Trade consumerism appears to be a huge opportunity to link the development of sustainable livelihoods to export opportunities.

The findings of this study will have important implications for the development of sensitized marketing strategies and more effective consumer education campaigns directed at this increasingly significant segment. It could also help translate the ideas and concerns of Fair Trade consumer into opportunities for Fair Trade organizations and developing country producers.

\section{Epistemology}

I approached this research project using a 'Critical' Epistemology.

According to Van De Dungen (Website 18), critical researchers assume that social reality is historically constituted and that it is produced and reproduced by people. Although people can consciously act to change their social and economic circumstances, critical researchers recognize that their ability to do so is constrained by various forms of social, cultural and political domination. The main task of critical research is seen as being one of social critique, whereby the restrictive and alienating conditions of the status quo are brought to light. Critical research focuses on the oppositions, conflicts and contradictions in contemporary society, and seeks to be emancipatory i.e. it should help to eliminate the causes of alienation and domination.

This research paper, then, is approached from the perspective that the lives of southern producers and northern consumers are inextricably linked via man-made systems and historical realities. It seeks to understand those links from a northern (specifically, New Zealand) consumer perspective, by focusing on the beliefs and practices of a small group of dedicated Fair Trade consumers. 


\section{Methodology}

Based upon the success of Shaw and Clarke's (1999) investigation, focus groups were deemed an effective means of exploratory qualitative data collection. Such an approach was necessary to explore how and when ethical beliefs are brought to bear on particular issues or principles important to the consumer.

Tallontire (200I) notes that there is a clear divergence between the support expressed for Fair Trade in consumer surveys, and actual purchase behavior. In other words, there appears to be many consumers who pay lip service to Fair Trade, but do not put their money where their mouth is. Subsequently, I decided to limit the scope of this thesis to the beliefs and behaviors of a very small group of dedicated Fair Trade consumers who had a solid grounding in the theory and practice the Fair Trade movement. The opinions of these participants, and the subsequent analysis of those opinions, is therefore not representative of all consumers of ethically-labeled products in New Zealand. In other words, these were not your 'typical' Fair Trade consumers. Looking at Figure I below, it is obvious that the affiliations of these participants with International Development would strongly influence the research results. They were a group of 'big picture' people who were actively connecting 'head' knowledge with 'heart' action. They came to the focus groups with an aboveaverage level of knowledge concerning trade justice and its implications for international development as a whole. As such they could offer opinions and ideas that were grounded in wider theoretical and practical knowledge and experience.

However, this also had a necessarily limiting effect on the research process. For instance, since all participants were admitted Fair Trade enthusiasts, there was no scope to gather information concerning their reasons for not purchasing Fair Trade

products. It was also unfeasible to gather more far-reaching quantitative information, such as statistics on actual numbers of Fair Trade consumers in New Zealand, the stores they purchased from, the most popular products etc. 
Rather, the research process was limited to exploring, in some depth, the beliefs and behaviors of this small group of dedicated Fair Trade consumers. It was the underlying assumption of this research project that, when effectively guided in group discussion, the expertise of these participants would translate into some valuable new insights that would contribute to the ongoing International Development conversation, and conversation around Fair Trade in particular.

As part of the recruitment process these consumers were asked to affirm personal Fair Trade consumption behaviors and commitment to Fair Trade ideals before they were invited to be part of the focus groups. This was done via a recruitment email that was sent to key management figures at Victoria University's Development Studies Department, Trade Aid, Oxfam, Amnesty International, the Development Resource Centre (who have extensive Development networks within New Zealand), Just Action (a social justice club at Victoria University), and Peoples Coffee. I already had networking opportunities in all of these areas, so recruitment wasn't too difficult. A purposive sample of Fair Trade consumers was then recruited based on the responses from these sources.

Due to time constraints and the timing of university holidays, participants were split into two groups. 4 participants were recruited for the first focus group, and II for the second group, for a total of 15 participants altogether.

Since the common uniting factor of these groups was the practice of Fair Trade consumerism, it was not considered important that these groups be organized in such a way to be homogenous in age, gender, religion, socio-economic status or ethnicity. Groups were rather selected on when they were available to participate in the focus group. 
From the information gathered from their initial email responses and through the focus groups themselves, the participants were affiliated with Fair Trade in the following ways:

Figure I:

\begin{tabular}{|l|l|l|l|l|}
\hline Participant \# & $\begin{array}{l}\text { Development } \\
\text { Studies Student }\end{array}$ & $\begin{array}{l}\text { NGO } \\
\text { Volunteer I } \\
\text { Activist }\end{array}$ & $\begin{array}{l}\text { NGO } \\
\text { Paid-Staff }\end{array}$ & $\begin{array}{l}\text { Fommitted } \\
\text { Fair Trade } \\
\text { Consumer }\end{array}$ \\
\hline I & $\checkmark$ & $\checkmark$ & & $\checkmark$ \\
\hline 2 & $\checkmark$ & $\checkmark$ & $\checkmark$ & $\checkmark$ \\
\hline 3 & $\checkmark$ & $\checkmark$ & & $\checkmark$ \\
\hline 4 & $\checkmark$ & $\checkmark$ & & $\checkmark$ \\
\hline 5 & & $\checkmark$ & $\checkmark$ & $\checkmark$ \\
\hline 6 & $\checkmark$ & & $\checkmark$ \\
\hline 7 & $\checkmark$ & $\checkmark$ & $\checkmark$ \\
\hline 8 & $\checkmark$ & $\checkmark$ & & $\checkmark$ \\
\hline 9 & & $\checkmark$ & & $\checkmark$ \\
\hline 10 & $\checkmark$ & $\checkmark$ & & $\checkmark$ \\
\hline 11 & $\checkmark$ & $\checkmark$ & & $\checkmark$ \\
\hline 12 & $\checkmark$ & $\checkmark$ & & $\checkmark$ \\
\hline 13 & $\checkmark$ & & & $\checkmark$ \\
\hline 14 & $\checkmark$ & $\checkmark$ & & $\checkmark$ \\
\hline 15 & & $\checkmark$ & & $\checkmark$ \\
\hline
\end{tabular}

Each group met once, for a two-hour session. Each session had a 10-minute break in the middle, with opportunities for participants to order more espresso coffee.

Focus groups were held at Zeal, a youth venue where I am currently a volunteer.

Zeal is a comfortable venue, with a Café-style environment and warm mood lighting. The idea was to simulate a relaxing Café environment where participants would feel 
safe and free to express themselves. Participants were compensated for their time via free Fair Trade espresso coffee (served by myself), Fair Trade tea, and biscuits. I also bought a Fair Trade chocolate bar for every participant as a thank-you for their effort.

The first focus group was held on June $25^{\text {th }}, 7-9 \mathrm{pm}$. Four participants attended (listed in Figure $I$ as participants I-4). The second focus group was held on July $2^{\text {nd }}, 7-9 \mathrm{pm}$. Eleven participants attended (listed in Figure I as participants 5- I5).

Though there were a series of set questions to cover, sessions were relatively unstructured to encourage participants to raise any aspect of the topic considered important. I acted as the moderator. Audio from each discussion was recorded and fully transcribed the following week. Participant's names were originally recorded in the transcripts to help me remember who said what, but for the purpose of privacy these names have been removed (as in Figure $I$ ) and replaced with numbers. The amended transcripts can be found in Appendix 3.

Focus groups explored:

- Participants perception of what the concept of Fair Trade actually means

- Feelings/emotions surrounding the issue of Fair Trade

- Other ethical issues that are important to participants

- Beliefs held by participants that influence their purchase behavior

- Informational and marketing influences on those beliefs

- Any concerns and uncertainties surrounding Fair Trade

The following questions were used to facilitate discussion when necessary: 
Beliefs and Ideas

- What does Fair Trade actually mean to you?

- What beliefs do you hold that influence your decision to purchase Fair Trade goods?

- What feelings/emotions do you experience when you think about Fair Trade or when you purchase Fair Trade products?

- What other ethical issues are important to you?

Marketing

- What do you understand about Fair Trade labeling? How important is it to you? Does it affect your purchasing decisions? Is information provided informative and involving? Have you experienced label fatigue (confusion due to too many ethical labels)? (tested recognition of Fairtrade label)

- What kind of marketing messages do think you respond to? Sick-baby/wellbaby? Why?

(Had examples of each ready for participants to look at)

Behavior

- Do you have purchase habits? If so, what are they? (where do you purchase from, what do you purchase, how often)

- Do you have a preference for a particular manufacturer (eg. Trade Aid, Peoples Coffee)? Why? 
- Apart from Fair Trade products, are there other ethical labels/kinds of product that you regularly buy? Are they more, less, or just as important to you as Fair Trade products?

Influences

- What information sources influence your understanding of Fair Trade and your decision to purchase Fair Trade products?

Concerns

- How concerned are you with value for money?

- Have you experienced any challenges due to being a Fair Trade consumer?

- Do you have any concerns about the FT movement - accountability? more information?

\section{Data analysis}

Field notes were taken during the focus groups, and further expounded immediately afterwards in order to capture salient themes from the discussion while they were still fresh in my mind.

Audio-tapes were transcribed directly after the discussion had ended. The transcription and analysis of the audio-tape from the first group assisted greatly in moderating the second group, as they helped refine the discussion questions. For instance, in the first workshop Participant 3 argued that building respectful relationships between Northern consumers/traders and Southern producers was an 
end in itself, regardless of Fair Trade's long-term success. After questioning him further, I noted that it could be useful to question the next group to see whether they had similar opinions. I later identified that developing principled north/south relationships was at least as important to the participants as the practical results of Fair Trade itself. This developed into the theme 'People of Principle' which forms the basis of my first analysis chapter.

Data was analyzed using Constant Comparison. Following the research questions as guides, every line, paragraph, or other section of transcript was coded for relevant themes using highlighted color-coding. As themes were developed, I assigned a working definition to each code. That way in going through the transcripts, the definition was continually being challenged, and some times new codes had to be developed because the properties do not fit the text. Codes that were rarely used were dismissed and some categories broadened to accommodate the lost code. This type of analysis was not linear, but circular. Categories and codes of new transcripts were compared with existing categories and codes in order to more fully develop the properties of the overarching categories for the individual codes. This process was on-going until saturation was reached (no new codes or categories emerged).

As my analysis began to reach saturation, a handful of key themes began to emerge. These themes represented common beliefs, traits, and concerns shared by the majority of the participants. There were seven key themes. These were:

I. Dedicated Fair Trade consumers are people of principle, whose choices and ideologies are governed by strong ethical beliefs and commitments

2. Fair Trade functions as a tool to reduce social distance between northern consumers and southern producers

3. Dedicated Fair Trade consumers have strong environmental concerns

4. Dedicated Fair Trade consumers are interested in exploring how Fair Trade can be further utilized as a tool to promote Global Citizenship 
5. Dedicated Fair Trade consumers are concerned about the corporate cooption of the Fair Trade concept

6. Dedicated Fair Trade consumers see the Fair Trade movement as a useful Band Aid solution that achieves modest development outcomes while promoting the major changes (or Brain Surgery) that are necessary at an international institutional level

7. Dedicated Fair Trade consumers believe that more strategic Fair Trade marketing campaigns and branding efforts can better achieve its short and long-term objectives

\section{Structure of this research paper}

These themes have become the basis for the main body of the thesis, and the critical discussion of my research findings. Key quotes from the focus groups are used in each chapter to develop ideas and arguments. The full transcripts from both focus groups are found in Appendix 3. The last chapter ties the chapters together and provides some conclusions and recommendations for the future of the Fair Trade movement and its possible implications for International Development.

\section{Definitions}

Please note that throughout this document the following convention is applied:

- 'Fair Trade' describes any trade that seeks to provide sustainable and equitable market

opportunity for marginalized or disadvantaged producer organizations, irrespective of whether it is independently verified or not. 
- 'Fairtrade' (one word) refers to the labelling system of Fairtrade Labelling Organizations International (FLO). The FAIRTRADE Mark is the Registered Trademark. Therefore 'Fairtrade products' specifically refers to products that carry the FAIRTRADE Mark. 


\section{Chapter 3: People of Principle}

Dedicated Fair Trade consumers are people of principle, and they are very aware of that fact. This group of dedicated consumers hold fast to their own ethical systems, and are often willing to support a cause simply for it's principles rather than it's practical results alone. Fair Trade is important to them because it is based on principles of fairness, reciprocity and justice.

"I have strong ethics" said one participant. "[Fair Trade is] important to me on an ethical level, its important to me to know that people who are producing products that l'm buying, and that the way that they're produced is done in an ethical and sustainable way; and that's related to my own belief system. It's intrinsically linked up to my own beliefs, what's important to me."

As my focus groups revealed, it seems that some Fair Trade consumers are happy to support Fair Trade simply to satisfy these ethical concerns, even if the movement itself were devoid of any revolutionary impact on economic realities. For some New Zealand Fair Trade consumers the 'justice' principles of Fair Trade have become an end in themselves, often superseding the practical purpose of Fair Trade, which is to provide people who are disadvantaged in the current trading system with a higher source of income. As one participant stated,

"Fair Trade is about two communities having a fair relationship first, before one community tries to jump in and 'fix' the other. People complain about the prices still being really low and living conditions not improving enough, but if you're getting the relationship right, and it is based on long-term respect for each other, then that's a great start".

This idea of 'just' relationships is the historical foundation for the entire Fair Trade movement (Website 23), so it was interesting to see Fair Trade consumers responding in turn with their own affirmations of this principle and what it means to them. Though the participants differed in the way they defined trade justice and its 
parameters, all felt that a certain degree of altruism in our relationships with other communities was necessary - even integral - to being a human being.

"[Fair Trade to me means] a Utopia" said one participant, "the idea that the world can be a just place, and that by doing something, by implementing Fair Trade, everybody's equal"

As Maseland and De Vaal (2002, p.253) have said, "the moral obligation to act in this Fair Trade manner stems from an idea of justice that lies underneath the Fair Trade concept. The conduct called Fair Trade, in other words, is an operationalisation of an idea of what just trade would be".

"Rather than talking about Fair Trade", said one participant, "I like

talking about Trade Justice. Shifting the words so people know you're not just talking about a label”.

The terms 'Justice' and 'Social Justice' tended to be a strong theme in the focus groups. While all participants felt that 'justice' was an adequate and useful term for addressing issues in trade, the groups hit problems settling on a single definition of what 'social justice' was. This is not surprising. Some scholars such as F. A. Hayek and Anthony Flew, argue that social justice is not in fact a kind of justice at all. Hayek is convinced "that the people who habitually employ the phrase simply do not know themselves what they mean by it, and just use it as an assertion that a claim is justified without giving a reason for it" (quoted in Flew, 1993, p.I I). While Flew does not quite agree with this statement, he does support Hayek's argument that social justice is not in fact a form of justice. He objects to "the identification of inequality with injustice, and to the assumption that extensive, state enforced, equalizing transfers of wealth and income from the better off to the worse off are mandated by justice" (1993, p.2). Equal shares for all (one interpretation of distributive justice, which is often associated with social justice) he argues, are not the imperative of justice; therefore social justice is no kind of justice at all.

Plato on the other hand defined justice as being "to render each their due" (The Republic). Indeed, there are few people who would argue, legally or morally, that the hard-working wage-earner is not entitled to a greater reward than his lazy neighbor. 
My research participants, in painting pictures of their utopias, did not assume that everyone was equally endowed with resources. The issue of contention, they insisted, was that farmers in developing countries were not receiving their due. In this sense, the flaws in the world trading system were a matter of injustice because they were keeping many from the due rewards of their labour. They were being exploited.

"[Fair Trade to me means] to stop exploitation" said one participant

In his De Officiis, the roman thinker Cicero clearly contrasts justice with beneficence, saying that justice can and should be legally required of us while beneficence should not be. Violations of justice inflict positive harm while failings of beneficence merely deprive people of a benefit and that duties of justice are owed to anyone. As mentioned earlier however, with our focus groups it proved more difficult to separate the concepts of justice and beneficence. Moore $(2004, p .6)$ highlights this conundrum, admitting that "the concept of justice underlies many of the principles on which Fair Trade is established and the assertion of injustice in conventional international trade is never far from the surface", but that a "fully worked-through theory of justice in relation to Fair Trade seems yet to have been produced".

From the perspective of dedicated Fair Trade consumers though, semantics seemed to matter little. Fair Trade, they felt, was about 'right relationship for its own sake'. "We often help people by throwing money at them" said one participant, "but there's no relationship there, no foundation of trust and understanding".

Participants were familiar with the key goals of FLO, one of which is to set "an example of partnership in trade through dialogue, transparency, and respect" (Website 23). Participants drew on this concept of partnership, highlighting the lack of sufficient dialogue as a historical factor in creating inefficient development partnerships, and therefore as a key issue in development practice today. As one participant pointed out,

"[Fair Trade is] not perfect, but it's a lot more based in dialogue than other stuff. Fair trade is about two communities having a fair 
relationship first. People complain about the prices being really low and living conditions are hard, but if you're getting the relationship right and based on long term respect for each other, that's what I like about it"

Since one of the founding principles of Fair Trade is partnership, the movement could be seen as a step in the right direction in addressing this dialogue issue. Dedicated Fair Trade consumers definitely seem to think so. Without the full participation of all the relevant stakeholders, we know that development funds can both perpetuate and exacerbate existing power inequalities. The development paradigms of the 1960s and 1970s derived from the legacy of colonial rule, especially the planning systems of the late 1930s and post-WW2 period. The conception was top down (development was something governments did for or to people), and the language military-bureaucratic (Website 19). Participatory Development was formulated in the mid-1970s, amid growing awareness that development efforts were having little impact on poverty. Since then an entire literature has emerged that is dedicated to identifying how both the intentioned beneficiaries and key stakeholders of development processes must participate in the appraisal and implementation of projects and programs (Reid, 2005), with transparency and dialogue as key components of any development efforts.

"[Fair Trade to me means] transparency”, explained one participant.

"I've been working with church groups who are trying to respond to poverty in the world, in ways that don't perpetuate problems, that don't perpetuate inequalities" said another participant, "and I think Fair Trade, basing itself in relationship, is quite good at that." We now know that with appropriate dialogue, both the benefits and pitfalls of development can be owned by all stakeholders, who are on a journey together toward a better future for all involved. 
This sense of journey and connectedness was important to the participants. They echoed Martin Luther King Jr.'s words when, in referring to the importance of justice, he said that rich and poor alike were all "caught in an inescapable network of mutuality, tied in a single garment of destiny. Whatever affects one directly, affects all indirectly." (Strength to Love, 1963, p.25) It is this sense of common humanity, and the accompanying moral implications that compel Fair Trade consumers to cross huge social and physical distances in their imaginations, making important (often sacrificial) decisions that affect people they will most likely never meet, finally manifesting these decisions in ethical consumer behaviour and other ethical/moral choices. This phenomenon of 'crossing' social distance is addressed more in the next chapter, as it is an important idea to explore.

Though terms like social justice, morality and beneficence can be difficult to define, it has been clear from these exploratory studies that dedicated Fair Trade consumers in New Zealand are a people of principle. They hold strong ideals, and see Fair Trade as one way to outwork those ideals - not only for their own peace of mind and satisfaction, but also to inspire and motivate their respective communities to rethink their own ethical apathy and moral stagnation.

"[Fair Trade is] like an end goal” said one participant. "An unattainable thing, like perfection, something to aim for." However extreme or moderate their personal altruistic principles, all participants articulated some version of a personal utopia as a long-term goal that these principles could ultimately bring to fruition. This strong sense of hope and idealism seemed to a diverse range of individuals together under the Fair Trade banner. In fact, most participants initially heard about Fair Trade through personal networks, not advertising.

"[I was introduced to Fair Trade by] people who support it" said one participant. "People who have come into my life in various ways."

"It's a social trend" said another participant. "People who influence you most lead you to it." 
As Martin Luther King said, "The hope of a secure and livable world lies with disciplined nonconformists who are dedicated to justice, peace and brotherhood." (ibid, p.17). It seems that this particular group of non-conformists have found their means of achieving brotherhood. As one participant testified,

"I think Fair Trade has created a sense of community.. I feel part of a Fair Trade community, through people l've met and things l've done. Similar to a faith community who all believe in something. I think that's really important... it does unify people with a range of beliefs under one banner. Other than religion and the environmental movement, what else do we have?"

Among its most dedicated proponents then, it appears Fair Trade has evolved from (in its early stages) an act of charity, to a living, breathing movement that has captured the imaginations of people of various backgrounds, all of whom have one thing in common - a passion for, and dedication to, justice. In that sense, the ethos and future of Fair Trade look to be in good hands. As one participant aptly put it,

"It's something I want to keep pursuing, investigating, and helping the area grow."

Though some economists and development theorists may look at the diminutive size of the current Fair Trade market and question its' ability to make any significant difference to the developing world, it appears this particular group of dedicated nonconformists are taking a stand on what matters to them. 


\section{Chapter 4: Social Distance}

Fair Trade is important to dedicated ethical consumers because it reduces the 'social distance' between them and those who grow their food and produce their commodities. It puts a human face on an inhuman product and serves not only to make the plight of the poor more real, but to remind the western consumer that impoverished people are more than just statistics. It also establishes the idea of producer and consumer as interdependent and equal partners, setting up a more healthy environment for future development - one based on a relationship with increased dialogue and participation by all parties.

"It's sort of like constructing ethical norms in society" said one participant, "so it's making ethics and justice and fairness into a norm rather than.. realist and capitalist approaches, [which are] very non-human. It really puts a human quality to trade and relations, not just between people but between countries and things that are abstract."

Interestingly, whilst the philosopher Cicero (mentioned in Chapter 3) believed that beneficence was not necessary for basic physical human needs, he did believe that it was a necessity for human fellowship. Fellowship, or social connection, was a strong theme in the focus groups. Having and outworking strong altruistic principles was seen as positive, but nonetheless difficult to maintain in a relational vacuum. For many participants, Fair Trade provided a relational reinforcement for their ideals by redefining the connection between consumer and producer.

"My lecturer invited some growers from Kuaapa Coco in Ghana, and they came and gave a talk, and it just really touched me at a very deep level."

It allowed them to cross a philosophical bridge "where meaning is attached to something someone has made" (Littrell \& Dickson, 1998, p. 184). This 'bridge' is called 'social distance' by anthropologists (ibid), and the shortening of this social distance has proved to be one of the key attractions of the Fair Trade market. Fair 
Trade products have begun to re-insert social meaning into otherwise abstract commodities, speaking to consumers about issues of authenticity, quality, fairness and justice. Ambitious as it sounds, many participants believe that the Fair Trade movement ultimately seeks to transform international market relations, forging new consumer/producer links based on trust, equity, and fairness in the process.

"The relationship itself is actually an end in itself" said one participant, "not just the means to practically provide people with a higher source of income"

In commenting on Fair Trade market, Raynolds (2000, p.299) notes that, "[i]f alternative products enter existing market circuits, their environmental and social qualities become subordinated to their price, as occurs with other commodities". Echoing the words of my focus group participants, she suggests that the way to counter this market discipline is to reduce the huge social distance that exists between producers and consumers (ibid, p.299). She reinforces this point by arguing that "theoretically it is in the process of capitalist exchange that commodities become abstracted from their human and natural roots, so that price becomes their dominant characteristic" and hence contends that Fair Trade initiatives "have begun to create new networks of exchange that escape the bonds of simple price competition" (ibid. p.306). It is this reduction of social distance and the subsequent strengthening in solidarity with the poor that many Fair Trade consumers enjoy.

"If we get rid of Fair Trade because we find out its not [working], at least we can keep that relationship base there [with the producers]. If we make Fair Trade about that, that it's about the relationship, then whatever it turns into, it'll be good."

Interestingly, TransFair USA (Website 24) asserts that it provides "personal relationships with farmers (through images, publicity, educational materials), trust and security in socially-responsible value claims" and the elusive life-affirming "feel good factor." In this sense, Fair Trade appears to be able to 'humanise' the trade process, making the producer-consumer chain as short as possible so that consumers become 
aware of the culture, identity, and conditions in which producers live. This was a strong theme in the focus groups, as echoed by this participant:

"I always say that Fair Trade is trade based on respect, and it puts people in the picture, people first, rather than a made in china tab or something, it actually puts people in the picture."

Reducing social distance can teach both individuals and communities more about each other - who they are, what life is like, and how it came to be like that. In a sense, it expands, clarifies, and sometimes entirely redefines their respective stories. New Zealand Fair Trade consumers believe that this will help to correct New Zealanders misconceptions about southern producers; for instance, the idea that the producers are impoverished due to laziness, simple-mindedness, or that they simply 'are and always will be' poor.

"That's what I like about Fair Trade" said one participant, "it takes away that superiority”.

In effect, the shortened social distance reminds us of our common humanity, and makes us uncomfortable with the fact that someone across the seas - someone who breathes, eats, sleeps, cries, laughs, just like us - is starving because they aren't paid enough for their hard work. The shortened social distance reminds us that those people aren't just numbers or statistics, but mothers, fathers, sisters and brothers. Participants who had visited producers in Latin America testified that the shortening of social distance works to correct misconceptions from both sides.

"[l first got interested in Fair Trade] when I got an opportunity to work in Mexico as an ecologist. And I also worked with some farmers on a project there buying Fairtrade coffee directly from growers in Mexico ... [The producers I visited] were really glad that people in the international community are aware that they're struggling and were trying to help them."

Fair Trade appears to send a message to producers that there are people out there who give a damn. As one Nicaraguan producer shared with Transfair, "Fair Trade ... gives us dignity. We are treated as equals." (Website 24). 
However, this reduction of social distance can often occur in a very piecemeal fashion, constructed from various odds and ends; stories about the communities who make or grow the product, or about their communities and the benefits of Fair Trade in particular or community development in general. While it has been common for New Zealand Fair Trade consumers to encounter these stories on handicrafts in Trade Aid stores, information on food products seems to be somewhat more elusive, especially espresso coffee blends that appear package-less in Cafes. Sometimes even the most diligent Fair Trade supporter is unable to find stories or reports on a particular community. Internet research by participants seems to yield testimonies from farmers only when they are required by some report or other. Participants were unable, for instance, to read the back of their coffee packet as they sipped their Fair Trade plunger coffee and find the necessary information that would direct them to the stories of their coffee's producers. Participants expressed a desire for more information on the Fair Trade coffee blends that were stocked in their local Cafes and supermarkets. Where were the beans from? Who grew them? What was their life like? Where could customers go for more information?

"It's important to me to know the people who are producing products that I'm buying, and that the way that they're produced is done in an ethical and sustainable way"

These questions and concerns all pointed to a central theme; the power of the story. The Co-Intelligence Institute (or the Cll) describes the power of the story as " a powerful way of organizing and sharing individual experience and exploring and cocreating shared realities. It forms one of the underlying structures of reality, comprehensible and responsive to those who possess what we call narrative intelligence. Our psyches and cultures are filled with narrative fields of influence, or story fields, which shape the awareness and behaviour of the individuals and collectives associated with them." (Website I). 'Story-reality', as the Cll calls it, is the reality that we see when we recognize that every person, every being, every thing has 
a story and contains stories -- and, in fact, is a story -- and that all of these stories interconnect. We are, in fact, surrounded by stories, embedded in stories and made of stories. "When poet Murial Rukeyser tells us "the universe is made of stories, not atoms," she's describing story-reality" (ibid). Ultimately, story-reality includes any and all actual events and realities.

It is those real-life, actual stories that are happening in the real world all around us all the time that help us make sense of the world around us, and to make sense of ourselves. Lois Carson puts it well; "The power of story and words to reflect the world we live in as well as to provide the imagination and vision necessary to reshape that world is infinite. Stories enable us to understand ourselves and others; they give us the power to sway an audience, to force change, to build bridges across ethnic and gender lines" (Website 2). Without being able to connect with other people's stories, they quickly become statistics that fail to move us and are irrelevant to our immediate lives. NGOs and charities have long known this, and that is why their marketing campaigns are saturated with the individual stories of real people with real problems. It is this resonance with the stories of others - the ability to see another's viewpoint and share another's pain - that keep charitable organisations alive.

But Fair Trade consumers want more. They understand the need for shocking marketing campaigns that stimulate the general populous into charitable giving, but what about those who are already motivated to see positive change? Many participants found media representation of the poor quite patronizing: "The manipulation [of consumers] through guilt ... that's not really constructive. It alienates a lot of people by making them feel fatalistic about what they can do" For those solution-minded people of principle, who desire justice and further solidarity with the poor and oppressed, the Fair Trade movement, with its empowering message of fairness and pro-active partnership, appears to have offered an alternative. It offers them a way to participate in development that is respectful and non-patronizing. 
"[Fair Trade] creates dialogue about the potential for change”, says one participant. "Its important not to go in and say 'we're here to help you', but, 'we're here to cooperate and work with you', so we not there to instill our western values and say "this is what you should do, you have to join our international trading system [on our terms]".. it's going in and seeing what the producers need and want for their own societies, and cooperating with them."

Rather than evoking guilt as the motivating factor, , Fair Trade appears to have built it's success - among its dedicated consumers - by reducing social distance and 'connecting' citizens of the minority world with the majority who produce their goods. 


\section{Chapter 5: Environmental Concerns}

Most of my research participants were concerned not just with human suffering, but with environmental concerns as well.

“I didn't come to Fair Trade right away" admitted one participant. “I

was more interested in environmental sustainability."

Despite its obvious potential to improve economic wellbeing, Trade also has the potential to devastate Earth's natural resources if it is left unchecked.

"l'm concerned about environmental impacts of trade, and how we're trying to reduce our carbon emissions" said one participant, "yet trying to trade with developing countries at the same time, which means air freighting or shipping goods. That will be a big challenge for Fair Trade, to stay aligned with sustainability."

Fair Trade, with its emphasis on sustainable farming practices, is perceived by most of its supporters as taking a step in the right direction. But is Fair Trade designed to keep up with the environmental movement and its recommendations on sustainability? What role does Fair Trade have to play in ensuring the Earth is userfriendly for future generations?

Depending on where you sit within the environmental spectrum will determine how extreme your definition of 'sustainability' is, but it is clear to everyone that we cannot carry on as we are. Robert Jensen, in his talk to Eton University, reminds us that "if all the people of the world consumed at the level of the typical middle-class American, the game would be over tomorrow. The earth cannot sustain 6 billion people living as we live in [America]. Over the long term, our society is unsustainable, and in the short term our society can continue only if people in other parts of the world are consuming far less" (Website 8). My participants were well aware of this.

"People in our society are scared because we know that if everyone in the world consumed like we did, we'd be screwed, but we're 
screwed anyway, because of our consumerism. It sounds cynical, but we can't all do this."

The problem is multi-faceted, but it's not hard to see that the Western consumer mindset has something to do with it. The middle and upper-class citizens of industrialised countries are accustomed to a certain standard of living, and our governments' policy decisions reflect that need. The USA and Europe subsidise their farming industries to the point where their commodities are sold for less than the cost of production. Cheap foods flood developing countries and devastate farmer livelihoods and food security, all for the sake of protecting European and American businesses and ensuring the continuation of the industrialised way of life. For many in the West, industrialization is Development. This represents a problem for many ethical people who end up consuming the products of this industrial complex;

"l've struggled a lot, combining environmentalism with development" admitted one participant. "A lot of the time the two are at odds with each other, and Fair Trade provides a way of integrating the two."

But what have the consumption patterns of the average consumer got to do with sustainability and development? Surely what we need is large-scale economic and political changes to overcome the problems inherent in capitalism and nation-states? Well, the problems are indeed political, but Fair Trade consumers would argue that they are also behavioural. Consumers have a lot of power over trade, because it is consumer demand that dictates what is valuable and what is not.

"Every individual has the power [to make a difference], markets only thrive because people decide what is popular" explained one participant. "If everyone chose to boycott something, that company would go under. There is so much power in your choice, in your decisions. I wonder if that could be more powerfully portrayed. They did [a poster] a few years ago ... it said 'you have the power'. 
A lot of people have said 'why are you promoting consumerism?', but what it's really doing is using your consumer power."

"It's similar to 'voting with your dollar"” agreed another participant.

"That's like empowerment and consumerism at the same time."

If humankind is to live in a sustainable relationship with the Earth, then the key environmental and social externalities of trade need to be internalised to ensure full cost accounting of the impacts. However, ethical consumers believe that this internalisation must occur not just on a corporate and political level, but also on the level of public consciousness. In other words, consumers need to realize the effect that trade has on the lives of others, and also the power that they have over the trade process. As one participant explained,

"A key thing I appreciate about Fair Trade is how it links with the environmental aspects of consumption in getting people to recognising the story of what the product is. There's power in that ... People still don't know that coffee grows on trees! That's a key thing, getting people to see the reality of what they're drinking."

The power of the story has been discussed in the previous chapter. Human beings use story to make sense of their life and the world around them. If consumers are unaware of just how much their own story touches and affects the story of the planet earth, they will continue to participate in the processes and over-consumptive lifestyles that destroy the very environment which birthed and sustains them. Even ethically-minded consumers struggle with this reality.. but at least they are aware of it:

"Personally I still find it difficult to get a lot of this stuff. I find it difficult to change my own consumption patters. But l'm recognising where stuff is coming from, and what it takes to create that thing. If Fair Trade can teach people that, and then the movement dies, I think you've achieved heaps." 
Luckily, consumers world-wide appear to be actively pursuing a deeper understanding of, and commitment to, issues of sustainability and consumption. Borregaard and Dufey, in studying the trade of sustainable products, have identified that "international markets for sustainable products are very dynamic with almost every country in the industrialised world expressing some preference for sustainable products, with consumers often being prepared to pay premiums for them" (2005, p.5). An study conducted by Information Resources, Inc (IRI) of 22,000 American shoppers found that $40 \%$ of those surveyed specifically looked for organic products to purchases, and that $30 \%$ looked for eco-friendly products and packaging (Website 16). It is certainly possible that the growth of the Fair Trade market has contributed to this phenomenon. Johnston has theorized that Fair Trade can help to undermine commodity fetishism and stimulate awareness of environmental issues "by forcing consumers to consider factors of production usually shrouded from view" (200I, p.7), and from the testimony of New Zealand Fair Trade consumers this would certainly seem to be true. The majority of research participants were passionate about environmental sustainability, and excited about both the current and possible synergies between the Fair Trade movement and the wider environmental movement. As one participant said,

"I think for the Fair Trade movement to move forward then we have to incorporate other movements that are ongoing, other revolutionary movements, like sustainability" (emphasis not mine)

Another participant further asserted that

“there's the whole idea that Fair Trade and sustainability are different... but they need to come together at some point. It's not going to work otherwise."

However, Fair Trade consumers are also very wary. They are aware that working both 'in and against' this industrial model puts Fair Trade in a precarious position - if it is not careful, it is in danger of supporting this industrial machine by sanctioning the high levels of consumption that have ravaged the earth already. 
"For me I see it as an interim thing" said one participant. "If I had the choice between buying everything at Trade Aid, and not buying anything at all, I wouldn't buy anything at all. Because buying stuff in itself causes lots of problems even if it is Fair Trade... it's not a solution in itself."

If Fair Trade wants to walk hand-in-hand with sustainability, it must be chronically aware of this. Historian Chris Brazier reminds us that " $[\mathrm{t}]$ he Western industrial model which science spawned still threatens to bring the life of the planet to an abrupt end through its relentless exhaustion and pollution of natural resources. [E]ven if enough corrections are made to our way of operating to save the earth from irreparable damage, it no longer seems possible for the 'virtues' of the Western industrial model to be exported to the whole of humanity" (2006, p. I34).

So can (and will) Fair Trade keep up with the wider environmental movement and its recommendations on sustainability? Or will it simply placate consumer consciences enough for them to carry on consuming at the same levels they already do, albeit with more 'ethical' products? Well, so far, the Fair Trade movement has successfully walked hand-in-hand with the increasingly popular Organic movement. Nearly 85 percent of Fairtrade certified coffee is also organic (Website 9), which is better for the environment and for the health of the workers. This has worked out well for both consumers and producers - increasing awareness of health problems in the West has sparked a huge growth in the Organic market, and producers in developing countries have taken advantage of this market. Since Fair Trade certification already involves fairly strict environmental criteria, Organic certification has been the next logical step for many farmers. "From the Southern producer perspective, the main alternative or complementary form of certification [to Fair Trade] is organic" (Moore 2004 , p.9). Having suffered serious health consequences from the use of harmful pesticides found in many large-scale agricultural and manufacturing centres, the return to traditional and organic farming techniques has been welcomed by many farmers, especially those producing Coffee and Cotton crops, over a million of whom 
are poisoned by their own pesticides every year (Website 10). One participant also reminded the group that when co-operatives receive the Fair Trade premium, they

"are more empowered to get off a subsistence lifestyle by

diversifying... producing products that better suit the environment

they live in. l'd like to see all trade become Fair in the future. That

way people wouldn't be sidelined by the main market, and people

would have enough knowledge, education and money to address

environmental problems."

Another participant told a story of her experiences in Mexico:

"Even though materially their lives were still quite difficult, [the

producers I visited] were sticking with the Fair Trade system

because it's a good model for fostering sustainability and solidarity

within the community."

The environmental and social benefits of Fair Trade have been well documented, and a range of reports and studies can be found at the FLO website.

The problem, though, is this; many ethical consumers are dissatisfied with the direction that the contemporary Organic movement has taken in recent years. As one participant pointed out,

"Organic and sustainable...don't always go together."

Often co-opted by corporations, the organic movement is used by many businesses to 'greenwash' products and services that support the same consumptive lifestyle that is destroying the environment around us. As award-winning Environmental Journalist Michael Pollan points out " ... in recent years organic has grown to include paradoxes such as the organic factory farm and the organic TV dinner. And now, there is even organic high-fructose corn syrup. We are not far from organic Coca-Cola" (Website 7). This is so far from the classic tenets of organic agriculture that it is astonishing.

This was a hot topic of debate among focus group participants. All agreed that the current level of consumption in New Zealand and other industrialised countries was both unsustainable and immoral in the way that it relied on the exploitation of the 
labour and resources of poorer countries. Fair Trade currently could only do so much to address this.

"The sustainability [aspect of Fair Trade] is particular to the farming methods" said one participant, "not to the shipping or packaging. So you can have Fair Trade coffee in a non-recyclable bag which has been flown here and has all these other attachments that aren't sustainable."

"I think that's an argument 'beyond' Fair Trade" said another participant, "it needs to take more into account."

As Sophi Tranchell, Director of The Day Chocolate Company said, “It doesn't make sense to import Fair Trade goods that we can grow ourselves. Buy Fair Trade tropical crops, and buy everything else local," she adds. "With climate change looming we should not be flying-in Fair Trade roses from Kenya for Valentine's Day and importing Fair Trade apples from South Africa when they are in season down the road". The problem, however, was the way forward. What would a sustainable and just society - in essence, a Utopia - look like? Most participants supported a compromise that mirrored that of Christian Ecology Link's (CEL) LOAF campaign (www.christian-ecology.org.uk). CEL advocates buying food that is:

\footnotetext{
L ocally produced,

O rganic,
}

A nimal-Friendly, and, where a product cannot be grown locally,

F airtrade

By these standards, Fairtrade products such as coffee, tea, cocoa and bananas would be recognized as a "best" option. Products such as Fairtrade apples and plums, however - while favoured over non-Fairtrade imports - would be regarded as second-best to locally produced fruits.

Participants adherence to the LOAF system varied, all flavoured and influenced by their particular beliefs and imaginations. Some avoided supermarkets altogether, even if they did stock Fair Trade or Organic produce. 
"Supermarkets are so unsustainable" argued one participant, "and go against any kind of de-centralising and becoming more sustainable. In the UK they have a huge share of the Fair Trade market, and its not really the direction it should be going in. You can get organic food in supermarkets really easily, but they can't be part of the solution. They treat farmers in the UK really badly. They don't care about the details."

What was unanimously agreed however was the need for Fair Trade to fight hard to stay aligned with sustainability, if it was to keep the loyalty of its current consumers, and to win more consumers in the future. Movies like Al Gore's 'An Inconvenient Truth' have pushed Climate Change and related environmental issues to the forefront of the public radar.

"Climate change will affect, and is already affecting, people in poor countries more than people in rich countries" explained one participant, "so you need to see [Fair Trade and sustainability] as inextricably linked."

Consumers are becoming increasingly interested in how their lifestyles affect the rest of the world. Thanks to the internet, the process of information dissemination, from scientist to citizen and vice versa, is increasing. When consumers go online for more information, they find cutting-edge groups like 'Beyond Organic' radio (www.beyondorganic.com), SustainableFuture (www.sustainablefuture.info), and A Better Future (www.abetterfuture.org). Fair Trade consumers are aware of, and connected with, these groups:

“There's a new concept called 'beyond organic' which is about incorporating all these ideas" enthused one participant. "There are all these conflicting ideas that need to be combined into one."

Having information from NGOs, Institutions, and even Bloggers at their very fingertips means today's consumers have the potential to be empowered and more educated than ever. If this happens however, they will also become more discerning (or more cynical) about what they buy. My research participants pointed out just one 
of the areas in which consumption of Fair Trade products was at odds with sustainability in New Zealand:

"[A big issue in New Zealand is] disposable cups", said one participant.

"That's one thing that shocked me about coming to New Zealand (from the Uk)" agreed another participant, "the amount of disposable cups people use, and lids!"

These concerns appear to have had a ripple affect, because many Fair Trade companies in New Zealand are exploring the idea of sustainability right down to how the product is packaged and delivered. People's Coffee in Wellington are developing a possibility for a new takeaway cup. The cup is biodegradable, compostable and made from renewable resources. The only problem is, they haven't figured out how to make sustainable lids for them yet.. but they're working on it. Pura Vida Coffee in the US (www.puravidacoffee.com) are one step ahead with 100\% biodegradable and compostable cups, and 100\% recycled coffee sleeves printed with soy ink. Another business to keep an eye on will be SolarRoast (www.solarroast.com). They are a completely carbon neutral company that uses a solar-powered coffee roaster to roast their beans.

"It's becoming popular for small businesses to promote themselves as carbon neutral" said one participant, "so why couldn't that be a part of Fair Trade business? I know local New Zealand businesses are starting to do that. Why couldn't that work?"

'Solar Roast' may not be Fairtrade certified, but they certainly know how to ride the recent wave of concern over climate change.

While Fair Trade cannot be all things to all people, it is crucial that the movement participates actively in the sustainability discussion if it is to evolve and stay true to its environmental principles as well as its social ones. It seems the Fair Trade movement has the potential not just to 'keep up' with the sustainability discussion, but to contribute to it. 
Having first-hand committed relationships with millions of small farmers around the world means organisations like FLO and IFAT are in a brilliant position to explore and implement ways that these people can have their voices heard in the international discussion on sustainability, where before they had been so often ignored, or simply drowned out amidst the louder academic and political voices. Just as the Fair Trade relationship can improve market information and access for small producers, perhaps it could also improve access to other forms of information and shift the balance of power, even just a little?

"If everyone cooperated in their causes" said a participant, "they'd probably make a lot more progress." 


\section{Chapter 6: From Ethical Consumption to Global Citizenship}

Even if they are consumed on a small scale, the very presence of Fair Trade products in shops and supermarkets has a what Paulo Freire would call a 'conscientizing' effect - in other words, they make you think. This fact has led dedicated Fair Trade consumers to conclude that Fair Trade marketing has the potential to not only grow its Fair Trade's market share, but to function as a catalyst in the development of 'Global Citizenship' and a more globally and ethically-minded society.

Global Citizenship is currently a common buzzword in the development arena. It has sprung from the perceived need to address the wide gap between the influence globalization has on peoples lives, and the actual awareness that citizens have of the realities of living in a globalised world. My research participants were chronically aware of this need.

"People are still so uninformed" said one participant. "You can see we need to address the bigger issues, but they are so complex".

More and more key development players (such as Oxfam or the UN) are promoting the idea that both nations and individuals should act as 'good global citizens', seeing their actions and decisions in not only a local context, but the also in the context of globalisation and its subsequent effects. Oxfam has even developed resources for schools who wish to incorporate global citizenship into their curriculum. Global citizenship cannot currently be expressed in any legal sense, but its seeds were planted in the consciousness of globally-minded people with landmarks like the International Declaration of Human Rights, and the forming of the EU and the WTO (Lagos, 2002). Translating the concept of citizen into a global context still presents difficulties however, not least of which is that global citizens are not legal members in good standing with a sovereign state. There are no recognizable privileges and duties 
associated with the concept of Global Citizenship that imbue it with the status and power currently associated with national citizenship. There is no global bureaucracy to give sanction and protect global citizens. However, Lagos (2002, p.5) points out that the lack of such an authority "gives primacy to the global citizens themselves: not a top-down but a down-up scenario." The lack of a world body puts the initiative upon global citizens themselves to create rights and obligation (ibid). With global citizenship, individuals exercise communicational and organizational tools such as the Internet to make themselves global citizens. No government sanctioned this development - it is a grassroots phenomenon.

For people of principle, like my research participants, the phenomenon of globalisation has been a double-edged sword. On one level it has brought technologies, resources and ideas to New Zealand that have radically enhanced our standard of living. Since New Zealand is almost incapable of producing any kind of computer-based technology itself, we rely on international trade to service the lifestyle that we now take for granted. But the reality is, many of our creature comforts here in New Zealand are only available to us because they are produced by workers who are not paid a decent wage. What is the answer to this moral dilemma?

"I think [your behavior changes] if you get more involved in Fair Trade" mused one participant. "You start to think more about it. You start to think about how you work and play, what you do with your time, what you read about."

It seems that for many people of principle who become involved in Fair Trade, the pain of staying the same is greater than the pain of changing. Fair Trade consumers, knowing what they know, cannot help but begin to see the 'bigger picture', and their strong sense of justice does not allow them to sit idle. This, in a sense, is global citizenship in practice. Ethical consumers already aware of their rights, become suddenly and acutely aware of their responsibilities as citizens of the world. 
While only some participants verbally articulated a commitment to 'global citizenship' as such, most in practice are quite obviously committed to some incarnation of the concept. More importantly they see Fair Trade as a conduit for the general masses toward a greater awareness of how our lives affect, and are affected by, people in other parts of the world. One participant felt that Fair Trade "really adds a much-needed human quality to trade and relations, not just between people but between countries and things that are abstract”.

Johnston (200I, p.I) speculates that this conscientious consumption "could serve as a conduit to a broader notion of citizenship, where an obsessive focus on individual 'choice', is replaced, or at least supplemented with a broader notion of community, sustainability, justice, and democracy." Many dedicated Fair Trade consumers testified that their involvement with Fair Trade has led them to become more actively involved in grassroots movements and move towards a greater sense of global citizenship in general.

But does Fair Trade work this way for everybody? If our goal is the development of New Zealanders into global citizens, then we are talking about something very ambitious. We are actually seeking to construct new psychological and social norms for society. But Fair Trade consumers want exactly that. They, along with many others the world over, recognise the very non-human aspect of capitalist culture, and see Fair Trade as a catalyst for furthering the salience of ethics, justice and the effects of globalisation in the public consciousness. As people of principle, they are committed to engendering the same attitude in their fellow countrymen. The scale of the task, however, is obvious.

"Given that it's so hard to change people's behaviour on a mass scale" one participant pointed out "and that most people in our society are market driven, don't you think Fair Trade is a way out? You can see the need to address the bigger more complex issues, but people often feel powerless to change things on a global scale. 
Surely smaller initiatives (like Fair Trade) give people that little push they need?"

Participants agreed that, while it was unlikely that the Fair Trade movement would grow to a big enough scale to ever be a panacea for all the inadequacies in the world market, it could be a powerful vehicle for raising awareness and fostering a more active and knowledgeable global citizenry.

"If you see Fair Trade in the supermarket" argued on participant, "at least you'll think about it... like, why are people buying this, what does it mean? Even if you don't buy it, because you can't afford it."

Participants recognised that, rather than there being a lack of information in industrialised countries concerning trade justice issues, there was an actually overwhelming amount. When it came to barriers to promoting Global Citizenship, lack of information was not an issue. Rather, the problem was the lack of motivation among consumers to do their own research and find the necessary details.

Participants believed this was due to the way that a lot of media represented the issues:

"I don't think portraying the reality of poverty is unethical" explained one participant, "it's the manipulation through guilt that's not really constructive. It alienates a lot of people by making them feel fatalistic about what they can do."

Fatalism was the key barrier to effectively promoting global citizenship identified by participants. Thanks to the internet, television, advertising and magazines, New Zealanders were swamped with images of orphans, slums, famines and disease epidemics. Rather than galvanising the country to action however, it seems this overload of information has left many paralysed and bewildered. The end result; no-one feels like there is anything to be done about it. Hopelessness sets in, which translates into Fatalism. We are an over-informed nation with a fatalistic attitude. 
This is where Fair Trade helps to overcome this barrier. As one participant explained,

"Its important to have both [aspects].. to portray the harshness of reality, and the solutions."

Fair trade appears to offer consumers an easy solution to justice issues, and as such it bypasses the paralysis of fatalism disseminated by the media. Participants testified to mothers, brothers, cousins, friends and associates who had been captured by the Fair Trade idea. Grandmothers were proudly displaying the Fair Trade tea in their cupboards. Schoolteachers were teaching their students about where their chocolate came from. Fair Trade, it seems, is giving people hope; the great enemy of fatalism and despondency.

Researcher: "Do you think there's a risk of people being fatigued by the sheer complexity of the issues?"

Participant: "Definitely, that's why Fair Trade is so cool."

"Its an easy way to participate" agreed another participant. "My mother gets excited about anything Fair Trade. At the high school she teaches at all the girls know about Fair Trade, and they all get one the internet to research it. Its producing awareness that there is a whole world out there that isn't fair, and that's gotta be a good thing."

After some discussion, the groups one key reason that Fair Trade was effective at avoiding fatalism and was accessible to consumers: its simplicity.

The Fairtrade label and its tagline - "a Fairer deal for third world producers" - is a brilliant move on the part of FLOs marketing team. Somehow, the hopeless complexity of the current trade problem has been distilled into those seven simple words. While some felt that this message was in danger of being oversimplified most felt that the simplification of Fair Trade's message was one if its key advantages and selling points. As one participant put it, 
"No-one really likes the idea of exploitation. If there's something you can do about it that doesn't require much effort, then people are happy to do it".

In this way, Fair Trade seems to achieve an uneasy tension in its marketing. The simplicity of its message gives hope, yet it retains enough of an edge that most of its supporters are impelled to act further. Fair Trade marketing seems to strike a balance between 'sick baby' and 'well baby' messages. In other words, Fair Trade makes you feel angry enough about injustice that you desire change, but simultaneously inspires enough hope for a better future that the average consumer feels empowered to make a difference and is not paralysed by a sense of fatalism. This sense of empowerment also comes with a new thirst for greater knowledge of the world and what makes its political and economic systems tick.

"[Fair Trade is] good because it acknowledges ... that we do have a commodity fetishism in our western culture. That's what the media promotes. Fair Trade is changing the motivation behind what we buy and why we buy things. It's encouraging people to start thinking about their own values and encouraging a new paradigm."

Fair Trade is not a Holy Cow to participants, however. Johnston (200I, p.7) warns us that alternative principles like Fair Trade "have the potential to both challenge and accommodate the dominant ideology and practices of consumerism and neo-liberal globalisation." This sentiment was echoed by many of the participants.

"People buy Fair Trade coffee and say "ooh, I'm saving the world, so I don't have to think about [anything else] anymore". But its not just coffee, its chocolate, it shoes, its clothes, pretty much everything we buy or use. So it narrows the focus down, so you stop thinking about the global picture and you just think about the few products you can buy that are Fair Trade."

They felt that in the simplicity of its messages Fair Trade was in danger of awakening the social conscience of the masses only to simultaneously placate that conscience with a range of products that did not encourage further research and action. 
"Some people argue that rather than being a step in the right direction, it's a step in the wrong direction, because the focus is in the wrong place, and you need to be to focusing on the world structures and politics that cause the problems in the first place. So why are people poor, and why do we think that we can have our shoes made by four-yr olds in Sri Lanka and it's not an issue? So instead of informing people about the whole global picture, its focusing it on these small things."

Although Fair Trade marketing seldom seems to paint a picture of Fair Trade as a panacea to global poverty, its very nature as a consumerism-based solution means that it is in danger of becoming just another a fad for those consumers wanting an 'ethical edge' to their image. Does involvement with Fair Trade always lead consumers onto the bigger issues, or does it sufficiently placate your conscience and altruistic sensibilities to the point where they do not investigate the world's social injustices further?

"I guess there are a lot of problems as consumer-based solutions to things” said one participant, “...seeing yourself as a consumer rather than as an active participant or citizen... implying that you can change things through what you buy, rather than doing anything more radical. I'm not suggesting that we stop importing things tomorrow.. I just think that the problem is deeper than just "buy everything Fair Trade and it will all be alright."

As Young (2003, p.II) points out, "PPM's (process or production methods) or TBT (Technical Barriers to Trade) and the other acronyms of the World Trade Organization are not evoked by a smiling grower on the side of a coffee pack”. "[If] you have no idea about markets or trade, and you don't know that there's people working in sweatshops in china" said another participant, "then you wouldn't really have any idea what Fair Trade means." 
It was with a mixture of distress and disgust that many research participants lamented the increasing incidence of Fair Trade consumption among some of their peers as nothing more than a 'fashion'. As one participant complained,

“I almost get offended when people buy it but don't really know much about it, or don't seek to know more... like its some kind of brand or some in-thing to do."

On one level, it could be argued that any rise in Fair Trade sales could be seen as a good thing, even for less than altruistic purposes. On another level however, if this trend leads to a dilution of the Fair Trade message, it could be in danger of losing its usefulness as a conduit to a greater social consciousness.

Dedicated Fair Trade consumers believe the key to solving this conundrum is more strategic education and awareness-raising campaigns.

"I think the only solution [to global issues] is wider education" argued one participant. "Getting people to see the way that it all fits. People I know who hadn't heard of Fair Trade till I told them about it would not even have an idea of the wider picture. They need little steps to get them there. Fair Trade provides that step, but it needs to be backed up by something further."

They have observed how the presence of Fair Trade products in supermarkets and shops has already raised issues in the minds of their friends and family about why the rest of the products in the store are not fairly-traded. Participants expressed much gratitude to Trade Aid in particular for their ability to offer a gentle yet firm introduction into the world of international trade and global inequality.

"I think Trade Aid makes a really good effort [to point its consumers towards the bigger picture]" said one participant. "I think a lot of other companies don't."

This isn't always the case with Fair Trade cafes and supermarkets, as one participant explained: 
"At the end of the day" explained another participant "when you buy your Fair Trade coffee [from a Café], unless you really push for the information, you won't necessarily get it".

It seems that a company's ability to educate and inspire its customers varies greatly depending on that companies priorities. In their mission to build just and sustainable communities, Trade Aid (2005, p.4) recognize the importance of strategies that "create public awareness at home of the ways that unjust trading patterns impact on the poor in developing countries." They seem to be doing a great job. For many dedicated Fair Trade consumers, Trade Aid has been the birthplace of their social conscience and the beginning of a journey toward global citizenship.

"Working at Trade Aid you learn a lot" said one participant. "You learn about individual producers."

While it is easy to pick up a Fair Trade product from a supermarket shelf and think no more about it, it is somewhat harder to walk into Trade Aid and not be curious as to the reason for its existence. Many consumers probably don't even realize they're being educated as they shop! Trade Aid also provides a place where Fair Trade enthusiasts can take their 'uniformed' friends under the pretence of shopping, then teach them about Fair Trade when they least expect it!

The Fair Trade exclusivity of the store and the enthusiasm of its volunteers (at least four of the research participants were Trade Aid volunteers) mean that Trade Aid seems to have become firmly planted in the consciousness of many New Zealanders. Participants informed me after the focus groups were over that Trade Aid staff also make efforts to deliver presentations of the Fair Trade concept to schools and community groups.

It appears that people can be educated and empowered as they go about their everyday business, without even realizing it. Big business has realised this for years. We don't realise how insidious advertising is until we start singing along to TV jingle from an Ad we hate, and are shocked to discover we know every word. In fact, John Pilger (200I) argues that "Today, most of humanity is subjected, in one form or another, to corporate propaganda. While the clichés have changed - 'the American 
way of life' has become 'globalization' - the essential aim is the same: to expand the power of capital, mostly Western and American capital, into most aspects of our lives so that almost everything is a commodity and the only value is measured by cost and consumption." Environmental activist Vandana Shiva calls this a form of brainwashing, or a "monoculture of the mind" (ibid). It establishes and enforces the status quo, discouraging beliefs and behaviors that do not suit the activities of these corporations. According to my research participants however, Fair Trade may be a useful tool for sabotaging this brainwashing process.

"Fair Trade is empowering rather than depressing" said one participant.

\begin{abstract}
"As a first step and a practical solution, Fair Trade can be very empowering for people who would otherwise remain apathetic to the situation", another group member went on to say. "I believe empowerment is the key to effective global citizenship".
\end{abstract}

It appears involvement in the Fair Trade movement not only stimulates consumers to re-evaluate their beliefs about consumption and trade, but the world in general. Its potential as a tool for promoting Global Citizenship is yet to be fully explored. It seems that any company that has an interest in growing the Fair Trade market may also have a lot to learn from Trade Aid's marketing strategies and awareness-raising campaigns, and this could be a point for further research and discussion. 


\section{Chapter 7: Corporate Co-option and Green-washing}

As Fair Trade becomes more salient in the public sphere, its name and icons run the increasing risk of being co-opted by other players in the market in an effort to whitewash their own ethical misdemeanours. Companies like Starbucks, Nestlé, Proctor \& Gamble, Dunkin' Donuts, and Walmart's Sam's Club are now all distributing Fair Trade lines of coffee (Caldwell, 2005). Anyone following the Fair Trade movement in recent years will be aware of the massive controversy this has caused. Dedicated Fair Trade consumers are adamant that in the midst of this marketing game Fair Trade must maintain a high degree of authenticity and transparency if it is to win the trust of the general populous and stand out among the wolves in sheep's clothing.

The involvement of multi-national corporations in the Fair trade movement is a touchy issue. Most ethical consumers are hyper-aware of the power of corporate rhetoric to hide the true intentions of big business.

“[Fairtrade] Labelling ... can be misleading" said one participant,

"and ... it can be used as a marketing tool rather than what it really

is."

While remaining extremely cautious, many focus group participants pointed out that, since multinational corporations hold a majority of the world's economic power, it would be a mistake to leave them out of the Fair trade equation. Participants welcomed the increase in Fair Trade sales, and saw the involvement of large corporations as a victory for the Fair Trade movement, albeit one that created a great deal of tension.

"There's a tension between the grassroots, really empowering people and making a difference, [and] widening the market" 
explained one participant. "There's the marketing side and the development side, and sometimes they are at odds with each other."

In a BBC News report of Nestle's release of a Fairtrade coffee blend, Harriet Lamb, director of the Fairtrade Foundation said "This just shows what we, the public, can achieve. Here is a major multinational listening to people and giving them what they want" (Website 12). Similarly, few people know that Starbucks agreed to carry the Fair Trade label only after Global Exchange, a human rights advocacy group, picketed the annual stockholder meeting and threatened mass demonstrations in front of coffee houses in 30 cities (Raynolds, 200I). It could be argued that, as in the Nestle and Starbucks case, rising consumer social consciousness can convince mainstream corporations to provide Fair Trade labeled products rather than face brandthreatening negative campaigns by advocacy groups. As one participant put forward, "[Corporate support for Fair Trade labeling is] good because it's moving Fair Trade into more popular thinking”

However, the question must be asked: does the addition of a Fairtrade certified product to a businesses repertoire simply a scheme to draw attention away from its misdemeanors in other areas? Many participants questioned the ability of the Fair Trade movement to stay true to its principles if such powerful organizations were involved.
"A real concern I have about Fair Trade is that it will move into (and it already is) a marketing tool, something that will be used by companies to make more profit. That's the danger of Fair Trade becoming more mainstream. So many multinational corporations are incorporating Fair Trade into their branding."

Moore warns us that "success in entering the mainstream ... carries with it the risk of dilution..[l]t is not difficult to envisage a situation in which the mainstream seeks to co-opt Fair Trade to its own ends." (2003, p. I2). In exchange, however, we risk granting "these not-always-ethical corporations opportunities to engage in "imagelaundering"' (Renard 2003, p.93). Indeed, it is not unlikely that most businesses still 
only see taking an ethical approach to trade in the context of reputation management. Young (2003) worries that for many of these corporations, Fair trade has simply been co-opted as one of many tools in their Corporate Social Responsibility armament, rather than as a basis for doing business". For instance, how many Fair Trade consumers know that Nestlé was awarded the Fairtrade Mark for just one product out of the 8,000 or more that it produces? How many know that Starbucks continues to use GMO ingredients in some of its products, and that so far Fairtrade coffee represents only I\% of the companies total purchases? (Website I3). Some of our participants knew this fact, though they admitted that their friends often ended up confused over the difference between becoming a Fair Trade organization and simply having one Fairtrade product.

"My friends think Starbucks is Fairtrade.. that's the perception. They spend a lot of money on making themselves seem like that."

Nestle and Starbucks have been able to capitalize on this confusion and 'cover all their bases', attracting ethical and apathetic consumers alike. In the meantime, neither company has changed their policies and practices in any other area, most notably Nestle's continual unethical marketing of baby milk in developing countries. Whilst recognising that the introduction of a Fairtrade product is a step forward, there is no reason for ethical consumers to suddenly relax their critical stance on these companies policies or review their support for the boycott of Nestlé. It is important that people of principle continue to urge such companies to work towards applying ethical standards in all areas and across the range of their products. Not surprisingly, none of the research participants frequented Starbucks, and few of them bought Nestle products when avoidable.

"Even in their pamphlets, [Starbuck's] propaganda never says they're Fair Trade, they say "oh look at us, and our happy farmers". Its bullshit! My friends think Starbucks is Fair Trade.. that's the perception. They spend a lot of money on making themselves seem like that."

"FLOs certification of a Nestle product.. it brings up questions for me." 
It's not just Starbucks and multi-nationals that raise alarm-bells with Fair Trade consumers however. Even New Zealand companies can use Fairtrade labeling in unethical ways:

"Esquires, a retailer [in New Zealand] charge a dollar extra for their coffee, even though they don't need to" pointed out one participant. "They're making extra profit of the perception of altruism."

But the problem isn't just the co-option of the Fairtrade label by mainstream corporations, but also the plethora of ethical labels that have been created in the wake of Fair Trade's market growth. There are now a range of ethical labels for consumers to choose from, all with varying degrees of authenticity and substance. One participant commented that

"Consumers hate that ... complexity.. they go to a supermarket, they're often shagged. They want it as simple as possible."

Some of the participants were confused between the IFAT logo and FLO:

"I thought IFAT were the ones who did certification?"

And some were even confused about the origins of Fair Trade labeling:

"I thought a guy from Costa Rica started it..."

Perhaps the most frustrating problem however with Fair Trade going mainstream is the issue of consumerism itself. From a sustainability point of view, we in the West consume far too much. A sobering report by the World Wildlife Fund (WWF) points out that "Earth's population will be forced to colonise two planets within 50 years if natural resources continue to be exploited at the current rate" (Website 20). The biggest proponents of this over-consumptive lifestyle are the Corporations. They have huge influence both at the WTO and in domestic trade policies. They spend billions of dollars a year trying to get you and I to buy more and more stuff. And as one participant poignantly pointed out,

"By buying anything from [a corporation], even a Fairtrade certified product, you are supporting them. Maybe we just need to stop 
buying much stuff at all. But that's a really hard message, because what do you need, and what do you want?"

"[Fair Trade is] not a solution to overcoming the way we consume, making people think "I can solve the worlds problems by buying more stuff'”'

Whilst the main message of Fair Trade has always been the ill effects of unjust trade on small farmers, it cannot escape its status as a social justice movement. Fair Trade is about living by principles, and as such it has partnered in many instances with the Organic and wider Environmental movements, as well as other justice-orientated movements everywhere. It also has to be comfortable with the fact that if is to truly succeed, it may end up making itself obsolete. As farmers continue to benefit from the Fair Trade premium, many have chosen to diversify their crops and grow produce better suited to their environment, both for sale on the market but also for their own consumption and food security. No-one is sure what a sustainable future will looks like, or whether Fair Trade as we know it will even be around. But as one participant said,

"If Fair Trade can teach people [about the effects of consumption], and then the movement dies, I think you've achieved heaps".

Ensuring Fair Trade does not sanction the over-consumptive lifestyle of the West will be difficult, and will require a lot of difficult decisions, consultation, and a high level of integrity from the Fair Trade Organisations (FTOs). Even with all the risks and uncertainties involved with going mainstream however, it seems dedicated Fair Trade consumers are interested in seeking ways to minimise these risks, while at the same time maximising the amount of trade that is conducted in a Fair Trade context. If done intelligently, this will contribute to the economic benefit of Southern producers and the ethical education of Northern consumers. 


\section{Chapter 8: Band-aids and Brain Surgery}

In spite of its diminutive size and sizeable opposition, the Fair Trade movement has succeeded not only in improving the lives of millions of farmers, but in highlighting the flaws in the current trading system and offering authentic inspiration for a better alternative. Some critics argue that Fair Trade is only a band-aid, when what world trade needs is brain surgery. With millions of poor farmers bleeding to death while the brains at the WTO and Wal-mart continue to malfunction, is it possible we need both? Dedicated Fair Trade consumers think so.

"[Fair Trade] means there's hope" said one participant, "because the people who are growing the coffee beams can invest in schooling for their kids, investing back into the land, so there's hope for the future, and their not locked into downward spiralling prices."

Twenty years ago most international development agencies were extremely critical of business and many saw it as an agent of underdevelopment (Young, 2003). Fair trade has been instrumental in bringing these two groups together and demonstrating the potential for business being an active and positive contributor to social development and facilitating the creative engagement that is now commonplace and effective. Although for many years a niche alternative market, the scale and influence of Fair Trade has never been greater. To date it has created a growing US $\$ 500$ million network of businesses, and provided a wide range of embedded services to producers who would not have been able to source or afford them locally (Redfern and Snedker, 2002, p.10). It has provided market access to groups whom mainstream business was not interested in trading with, and has successfully campaigned at many levels of policy making to bring real pro-poor changes in legislation (ibid). It has facilitated or influenced the increasing number of Fair Trade products on 
supermarket shelves, and by doing so has raised the issue of trade with millions of consumers - particularly across Europe —changing attitudes to business and development (ibid). It has been a significant catalyst in the development of ethical issues within mainstream trade and business practices, influencing the development of Corporate Social Responsibility, approaches like Social Accounting and the development of the Ethical Trade Initiative in the UK (ibid).

Despite these successes, its critics argue that Fair Trade is only a band-aid, when what world trade needs is even Free-er trade. Tim Wilson, a writer for the Australian Financial Review. claims that "developed countries have escaped poverty because they chose the de-centralised, wealth-creating free-market system" (2006, P.I). To a large degree, this is true. Studies, such as Oxfam's Rigged rules and Double Standards (2002), point out that Free trade has the potential to act as a powerful motor for the reduction of poverty, as well as for economic growth. But that potential is being lost, because the very countries that Tim Wilson congratulates for 'escaping' from poverty have done so thanks to their own forms of heavy protectionism and simultaneous leveraging-open of developing markets. One participant was quick to point out the hypocrisy of such claims from Fair Trade's critics;

"There's tariffs and taxes and all of these barriers and exceptions and rules that countries add to free trade. I think it's a bit hypocritical to say Fair Trade is bad because it restricts the market when free trade itself is not free." "[Fair Trade to me means] a fair dividend of profit" said another participant, "not just for retailers, but also for the growers"

However, as Berndt (2007) points out in her field study of Guatemalan and Costa Rican coffee growers, Fair Trade is far from perfect. She believes that the benefits of Fair Trade can go straight to small landowners and often fail to reach the poorest of the poor - the hired workers themselves. In specialty coffee-growing areas, Berndt 
sees Fair Trade at best as a "Band-Aid solution to the problems a deficient institutional structure creates in coffee-producing countries. Reforming the institutional framework to foster entrepreneurship and trade can better address the main problems Fair Trade attempts to resolve, such as low pay for the poorest segment of the population and the erratic business cycle" (2007, p.3). Dedicated Fair Trade consumers seem well aware of this fact, however.

"I don't see [Fair Trade] as a panacea for alleviating poverty" said one participant, "its just part of the process of dealing with the world's ills"

Historically, Fair Trade originated for exactly such a purpose. Deficient institutional structures, both domestically and internationally, are why the Fairtrade market was established in the first place. As far as this researcher is aware, Fair Trade has never claimed to be a long-term replacement for these institutions. If it has, it has probably overstepped its boundaries.

"The free market originated from an ideal" pointed out one participant. "In the same way Fair Trade isn't an original idea, but an alternative."

"The biggest obstacle to ethical trade is the current international trading system" continued another participant. "You can't get around it, and unless that changes there's no way that Fair Trade will make a long term or sustainable impact on developing countries."

Scholars and development workers have long observed that Fair Trade's primary benefit is as a stepping-stone toward a shift in popular mentality that would bring fairer laws and institutions. "Fair trade is not the answer to the problems less developed countries have with trade" says Young (2003, p.12) "it needs to actively and effectively work for and encourage consumers to push for changes in trade rules that deal with the macro issues. Otherwise, it risks becoming part of the problem." $A$ cursory reading of Fair Trade marketing and literature will show that this is the full 
intention of organizations like FLO and IFAT. "We don't for one minute think the solution to all problems in world trade is Fairtrade" says Harriet Lamb (Website 14) director of the Fairtrade Foundation. "We're helping to create an atmosphere in which many people can play their part in many different ways. What we want to create is a situation where it is no longer acceptable to do nothing, where every company, and every individual, has to do something to make the world fairer". Participant's seemed to echo this mindset, explaining "[Fair Trade is] not a solution in itself, its not perfect. But it's knocked in, it's a challenge, its challenging the traditional capitalist system, while it works within it. That's all important to me, challenging the status quo rather than just going along. No system is ever going to be perfect, we can never create the perfect Fair Trade system, but if you're always challenging the way things are, that's development."

"For me" explained another participant, "[Fair Trade is] not a solution, its part of paradigm shift towards being more holistic about life"

Organizations like Oxfam, famous for their campaigns on macro-issues, offer Fair Trade their full support. It is clear that Fair Trade aims to be a flexible substitutiary arrangement that, while not perfect, can temporarily override many of the flaws in domestic laws and international trade systems. While these flaws still exist, Fair Trade exists to minimise the damage they cause to the poor. It is a band-aid, keeping many farmers from bleeding to death while the wider development community attempt to perform brain surgery on the institutions responsible for their malady. If and when this brain surgery is successful, Fair Trade will have happily made itself obsolete. One participant expressed it like so

"For me [Fair Trade] like a system within the capitalist system that corrects a by-product of [that system] by prioritising people and sustainability, but still using capitalist-based models and trading systems" 
While Fair Trade may be performing adequately as it is, the concerns Berndt raises over the rigidity in the Fair Trade labelling criteria for coffee farmers cannot be ignored. Berndt (ibid, p. 36) warns that, because coffee is grown in a large variety of contexts by a variety of people, Fair Trade should not impose a 'one-size-fits-all' organisational structure on the producers it works with. At the moment Fair Trade only deals with coffee farmers who operate in a co-operative context. However, choosing to work with Co-operatives was a very deliberate and thought out decision on FLO's part. The power differential that exists between small farmers and traders can more easily be addressed through farmer organisation and pooling of resources. This results in faster and more codified (often documented) knowledge transfer. Representatives of central co-operative organizations visit several villages of member co-operatives and are exposed to successful projects that they can then share with other co-operative members through formalized communication channels. Farm workers can start new joint business ventures, spreading the risk of failure among several members. Once organized into a co-operative, farmers can pool their income to purchase a phone, fax, and Internet service to ensure access to current market information. Cooperatives can offer storage facilities and warehouse shelf-stable product during low-priced markets to protect themselves from market fluctuations, benefiting their farmer members by using information about future prices to control when they sell. So far, it seems to be benefiting these people, if the impact studies are anything to go by. One participant testified first hand to the benefits of a co-operative in Mexico:

"I learnt ... that even though materially their lives were still quite difficult, they were sticking with the Fair Trade system because it's a good model for fostering sustainability and solidarity within the community, and that's what a lot of producers often said, its not actually the extra income that's the real benefit, it's the structure that goes into the community... so that was really important for me." 
According to Nicholls, Fairtrade networks also appear to benefit producers in their non-Fairtrade transactions through access to information and reputation enhancements by being involved with the Fairtrade movement (Nicholls, 2005). In South Africa, Fair Trade is actually promoting entrepreneurship because it is linked to the government's program to make black workers co-owners of plantations owned by whites. Plantations must be at least $25 \%$ black-owned to enter Fairtrade (FLO, 2005). It seems whether Fair Trade lives or dies, it appears to be functioning as an invaluable capacity-building mechanism in the meantime.

Unfortunately, any farmers unable to operate in a co-operative context are currently left out of the Fair Trade equation. While this situation is not ideal, Fair Trade has chosen this path in order to make sure that it does not simply propagate the same unbalanced power structures that caused wealth to accumulate in the hands of coyotes and middlemen in the first place. In the past this stringency was never too much of a problem, because the Fair Trade market was so small that it only could only offer itself to a fraction of the farmers who satisfied its criteria anyway. Now however, as the Fair Trade market gets bigger and more and more consumers are aware of what it does, it may need to review this situation. According to Starbucks' spokesman Andy Fouche, the very nature of fair-trade coffee production excludes the possibility of 100 percent participation on the part of large coffee companies like Starbucks. "Fair trade only certifies smallholder farms organized into cooperatives, and that represents about 2-3 percent of the worlds coffee farmers," he said. "We support coffee on a global scale, and that means we buy not only from smallholder farms, but from medium- and large-scale farms and coffee estates, as well" (Website 15). While Fouche is right to be concerned about social standards in medium and large-scale farms, in actuality $70 \%$ of the worlds coffee is grown on farms of less than ten hectares, and of this, the vast majority is grown on family plots (Oxfam, 2002).

The Fair Trade movement started out as a trading partnership which aimed at sustainable development for excluded and disadvantaged producers. Should Fair 
Trade then, without lowering its standards, evolve to meet the needs of everyone else as well? Scholars and supporters are divided on the issue, as were my focus group participants.

"There are lots of communities in which the current Fair Trade model isn't suitable" said one participant. "They have a low capacity and are geographically isolated ... it's not even possible for them to get Fairtrade certified in the first place. For me I think that's got a lot to do with the rigidity of the model as it is now, and also how it needs to be de-centralised to be more sensitive to local situations, and I think that's one way it may evolve in the future."

In the future it may be worthwhile for the Fair Trade movement to investigate just how many small farmers are excluded from participation in the Fair Trade process because of their inability to join co-operatives. If the number is significant, organisations like FLO might consider ways of including those small farmers 'lost' in the cracks. In the meantime, the Fair Trade coffee market is still not big enough to accommodate the participation of all the small farmers currently eligible to do so, never mind those ineligible. Without further Fair Trade market growth, opportunities for producers to hop on the Fair Trade bandwagon will remain limited. Producers currently on the FLO register sell only a portion of their harvests via Fair Trade channels, with typically over half of their coffee still going to conventional markets (Rice and McLean, 1999, p58).

In establishing its trade relationships and the certification procedures surround those relationships, Fair Trade must also be careful to avoid encouraging more small farmers to enter into the coffee industry - after all, it was the oversupply of coffee on the world market that caused the price slumps that decimated small farmers' livelihoods in the first place. Knowing this, many economists are critical of Fair Trade because it is perceived as manipulating the market by artificially raising coffee prices. FLO are aware of this danger however, and encourage farmers to use the Fair Trade premium to diversify their crops in order to obtain greater food security and explore other business endeavors. One participant testified to this first hand, saying 
"In Guatemala, there are cooperatives who not only grow exportorientated products, but use the Fair Trade premium to work on subsistence farming as well, which I think is a great thing because it gives them food security, and reduces their reliance on exports"

Dedicated Fair Trade consumers see Fair Trade as useful to producers in two ways as a financial 'crutch' to support suffering farmers who are prevented from reaping the full benefits of trade by the institutions around them, but also as a capacitybuilding instrument that provides information and resources to enable farmers to participate in the world market more fully and safely, and to participate in their societies in more meaningful ways. Fair Trade may only be a band-aid for small farmers, but it seems to be doing some much needed healing. Fair Trade consumers are glad of this fact, and are interested in ways that a less rigid certification model might reach more people who are yet to reap the full benefits of trade. 


\section{Chapter 9: Advertise and Proselytise}

Canny marketing is essential to any business-based endeavor. In industrialised society, thousands of messages and brands compete for our attention and loyalty everyday. How can Fair Trade market itself into the future in both a strategic and ethical way? Is growth its number one goal, or does the quality of information and ideas it conveys equally important?

Everyone is selling something. We are bombarded with thousands of messages every single day, a mixture of compelling propositions and calls to action by companies with multi-million dollar marketing budgets who manage to grab our attention at every opportunity. These messages tell us how we should be living, how we should be looking, where we should be going, and what we should be doing. They are insidious, and they are everywhere. Fair Trade consumers are convinced that a better future is dependent on a different story being told.

"I think the power of [consumer choice] isn't tapped into as much as it could be" said one participant. "Every individual has the power, markets only thrive because people decide what is popular. If everyone chose to boycott something, that company would go under. There is so much power in your choice, in your decisions. I wonder if that could be more powerfully portrayed."

As we have already discussed, there is an increasing push by NGOs to inspire ordinary people to become 'Global Citizens', aware of how their lifestyle choices affect people across the globe. But with fierce competition from less-than-moral corporations, how do grassroot movements like Fair Trade stand a chance of finding their way into the public conciousness, especially when they are so often criticised for spending money on themselves? 
This is where branding comes in. Companies like Coca-Cola and McDonalds have used brilliant branding to get to where they are today, by making themselves appeal to a wide demographic of people. With the emergence of recognizable labels like the FLO logo, non-profits are starting to do the same. Professor of Marketing at the University of the West of England, Adrian Sargeant (Website 3) comments: "Interest in branding [among non-profits] seems to be growing, those charities which bring in most money have long recognised the benefits. But now an understanding of the need for branding seems to be permeating the whole sector... and with good reason. Successful charity brands can have a very positive impact on how organisations perform, how donors feel about them, and on the income they get."

Potential donors will encounter a non-profit's brand before they have any interaction with the non-profit itself, so it is vital that the brand identity conveys the non-profit's visions and values whilst still appealing to the target audience.

"[With Fair Trade marketing] you get these lovely images of what you're doing in the world" admitted one participant, "and I guess that's where the idea of a utopia comes from"

A brand identity is a non-profit's chance to make that crucial first impression and shape the way the public perceives them. If the public don't understand what the brand stands for, they cannot be expected to buy into its essence. The visual and verbal language used in a non-profit are therefore pivotal to its development (Website 3).

A good 'brand' cannot be created overnight, It comprises factors such as trust, reliability and donor loyalty which can only be earned over time. But distinction over other similar organisations can be addressed immediately through communicating clear key messages and can have a considerable positive impact on the perception of the charity. Too often charitable organisations will chose the cheapest marketing option available to them simply to avoid criticism from the public (Website 25) "after all every last penny is expected to be carefully watched and justified - but is it 
not considered better to spend more money wisely and make a real impact for the good of the charity than less, ineffectively"?

But what branding exists currently in New Zealand that conveys the Fair Trade message?

"A range of sources [influences my understand of Fair Trade]" said one participant. "Going to talks, magazines, newspaper articles, internet, talking to people.”

Successful brands have sprung up within the Fair Trade movement. In New Zealand, we have strong brands like Trade Aid. Many of the participants expressed a strong relationship with Trade Aid, and many credited the store with starting them on their Fair Trade journey.

“I just really liked [Trade Aid]!” said one participant. "I went in there, and it went from there really".

Urbanites are no doubt also familiar with coffee companies like Peoples Coffee and Esquires, who exclusively sell Fairtrade certified coffee bearing the FLO logo. Sales of FLO labeled coffee, introduced to New Zealand in 2003, have grown to over New Zealand $\$ 4$ million, so the logo must be doing something right (Website 26). One participant observed that

"It's good to have a logo that people can recognize, because most consumers wouldn't go to those lengths to do the research [on where their coffee comes from]. They want to be in and out of the supermarket, so if they spot something visible that helps them out." Compared to the UK, New Zealand has less of a variety of Fair Trade brands and labels.

"[This] actually reduces label fatigue" said one participant.

But while these brands have been very successful in their own right, focus group participants were uncomfortable with the plethora of marketing messages and brands existent within the Fair Trade movement.

"Consumers hate complexity," said one participant, "they want things as simple as possible”. 
It seems even the ethical market can over-saturate its consumers with too much information from too many directions.

“I rarely pick up Fair Trade flyers [anymore]” said one participant. "It's the same old stuff to me. It's not marketed at me. I did pick it up once, at Trade Aid. That worked back then, but not any more. [Now I look at ] websites for products, organizations and events." While the FLO logo has offered a means by which to identify Fair Trade products, it is not just the products themselves that do the marketing. The vast majority of products in Trade Aid - handicrafts for various kinds - don't bear the FLO logo. In such instances the bulk of marketing is done via posters, flyers, educational presentations by Trade Aid and other NGOs, and even news announcements on TV during Fair Trade fortnight. These all present their own messages and interpretations of the Fair Trade movement.

To a large degree this wide array of messages have been effective in recruiting support for the cause. As one participant commented

"Even friends who are undecided on the legitimacy of the Fair Trade movement at least know about it and are thinking about it."

This variety of messages and 'languages' does represent a problem however; they could lead to different interpretations of what Fair Trade actually is. With big corporations like Nestle and Starbucks jumping on the Fair Trade bandwagon, the main message of Fair Trade is already in danger of being diluted or lost amidst reams of ethical rhetoric. Not even the FLO logo is entirely trusted, as many participants testified.

Researcher: "Do you trust [the FLO logo]? Does it represent any certainties?

Participant I: "Depends what it's on. If it's on a Trade Aid product, yes. But if it's on a Scarborough fair product, not so much. I'm a bit sceptical." 
Participant 2: "It does lend its credibility to a number of products. But if you were really interested in what you were buying you'd do some research on it."

There are also many Fair Trade products that cannot be FLO-certified, and also many producers who are not in a position to have the logo stamped on otherwise certifiable products because of the rigidity of the labeling process. So how can Fair Trade be marketed in such a way that does not create unnecessary confusion and misconceptions about the Fair Trade message?

In 2007, two marketing students at Canterbury University in New Zealand, Sarah Martin and Fiona Hartley, conducted a series of focus groups on campus that explored students' awareness of Fair Trade. Though several marketing tools were identified as successful in reaching students, the focus groups found felt that there did not appear to be one consistent communication method that appealed to all groups. Martin and Hartley (2007) concluded that using an integrated approach amongst a variety of media vehicles could increase the likelihood that awareness will take place amongst the majority of consumers. Martin and Hartley (2007) suggest exploring the field of 'Integrated Marketing Communications' (IMC) and seeing what it has to offer the Fair Trade movement. Simply defined, IMC is "a management concept that is designed to make all aspects of marketing communication such as advertising, sales promotion, public relations, and direct marketing work together as a unified force, rather than permitting each to work in isolation" (Website 5).

If FLO and IFAT stakeholders were to work together on an IMC strategy, it could result in the creation of some universal marketing tools that could then be disseminated across the Fair Trade movement. These marketing tools would need to focus on areas where the information available to consumers was currently confusing or unclear. While the research participants did not articulate any ideas regarding an IMC strategy per se, their ideas did point towards a holistic, strategic approach to 
Fair Trade marketing. As such I believe it is helpful to look at their ideas concerning Fair Trade marketing in an IMC framework.

There were three key areas where my focus group participants felt current marketing efforts were lacking, making them potential strategic focus points for an IMC strategy, or any marketing strategy at all.

The first of these key areas was 'information'. One participant said "[l] talked to a few people, and they think that most of the money doesn't go to the growers themselves. They think it's going to the Fair Trade organisations, and not benefiting those who grow the coffee in the first place to a significant degree".

Participants did not link this trend to a lack of information per se - in fact, one could argue that there is an overwhelming amount of information floating around concerning Fair Trade - but to a lack of relevant information that directly targeted consumers concerns and questions about Fair Trade. For instance, where exactly does the $\$ 3.50$ they pay for a cup of coffee go?

"[Consumers] need to be informed what is happening" said one participant, "like a breakdown of the purchase price and how much money goes where".

Martin and Hartley experienced similar concerns; "Both groups agreed that you want to know where your money is going - how does it benefit the whole community? What does that 20 cents actually means to a farmer and his community in the third world countries?" (2007, p. 10). The Canterbury students wanted to be guaranteed that the additional money that they were paying was actually contributing towards the cause and were interested in taking it to their local Cafe and asking where the additional 20 cents was going. "They wanted to know they weren't simply being ripped off' (ibid). 
The second key area identified as a possible focus point for IMC is the concept of 'authenticity'. One participant confessed

"[Fair Trade] almost seems quite scary, like a kind of marketing ploy. You often don't know what it's about as a consumer, you just buy it because it makes you feel good".

This was also debated in Martin and Hartley's focus groups "I think people get confused that no one is making money out of Fair Trade, they must be ripping me off, something is wrong here!" (Hartley, 2007, p. 10). Despite perceived distrust of some Fair Trade brands among a few of my focus group participants, all participants expressed confidence in two brands - FLO (specifically their logo), and Trade Aid. As one participant explained,

"There are some Fair Trade brands or labels, like FLO, that you know you can trust, because you know that people pay for that certification."

When shown the FLO logo, participants recognised it instantly, even if they were unsure of who FLO was. By far the most recognised and trusted Fair Trade brand however was Trade Aid. As discussed in Chapter 6, Trade Aid offers a complete package to Fair Trade consumers,. A brand, a store, a local history, and face-to-face contact with store workers that can answer their questions. Many ethical consumers commitment to Fair Trade began in a Trade Aid store. It's simple, its easy.

“Consumers hate complexity," said one participant, "they want things as simple as possible".

One of the key factors identified in the success of Trade Aid and FLO-labelled products in generating an atmosphere of authenticity was the power of the story. This is discussed in more detail in Chapter 2, but put simply, consumers concerns and doubts about a charitable operation seem most often assuaged by the testimony of its beneficiaries. 
"My lecturer invited some growers from Kuaapa Coco in Ghana" said one participant, "and they came and gave a talk, and it just really touched me at a very deep level."

Hartley noticed that their focus groups enjoyed Trade Aid's current practice of including biographies about the coffee growers on the inside of their chocolate wrappers, although they "did find it strange that it was only on the dark chocolate wrappers" (ibid). Matt Lamison of People's Coffee also recognizes the power of the story. "We realise that most people tire of repetitive rhetoric about Fairtrade" he says. "It is therefore essential to make the message resonate for the consumer in a more profound, less abstract way...We travel to our cooperatives annually so we keep connected to the fascinating story of the growers" (Website I I).

The third and final key area that an IMC might target is the concept of 'consumer empowerment'. This was where the power to advertise could also be used to proselytise. Focus group participants felt that marketing information needed to both enlighten consumers and equip them, practically and psychologically, to address issues in a meaningful and effective way.

With the information overload brought by globalisation, it appears that a simple 'guilt trip' no longer has the same effect on overstimulated consumers.

"I don't think portraying the reality of poverty is unethical" asserted one participant. "It's the manipulation through guilt that's not really constructive. It alienates a lot of people by making them feel fatalistic about what they can do. Its important to have both: to portray the harshness of reality, and the solutions."

Participants testified to feeling 'overwhelmed' and 'dismayed' by the amount of issues and causes that global media had brought to their attention. The result tended to be mental and emotional overload, and a subsequent 'shutdown' of ethical and moral faculties in order to make the issues 'somebody else's problem', because the media that brought the issues to their attention usually fails to present any viable solutions. If people feel that their contribution to a cause is of little consequence, the resulting 
despondency will either terminate or handicap any further efforts to support that cause.

If the Fair Trade movement is to market itself into the future in both a strategic and ethical way, it appears that tapping into the ideas of its dedicated consumers will provide it with a rich source of ideas and information. Their ideas regarding quality of information, simplicity, and images and language that empower rather then paralyze could prove invaluable in any efforts to strengthen and grow Fair Trade brands, and win 'converts' to the cause of trade justice. 


\section{Conclusions}

"We can make the future of Fair Trade what we want it to be!" (Paul Myers, 2007, p.I)

I have structured the conclusions of this research paper in such a way as to answer my initial research questions from Chapter 2.

\section{Research Question I:}

What ethical beliefs are held by dedicated New Zealand Fair Trade consumers that influence their purchase behavior?

- They are people of principle who are committed to ideals and not just practical results.

Basing itself strongly upon qualitative principles rather than quantitative results alone has been crucial to Fair Trade's success so far, and the reason it has hope for the future. It has captured the imaginations of strongly principled people, represented only partly by my research participants. This group of dedicated consumers hold fast to their own ethical systems, and are often willing to support a cause simply for it's principles rather than it's practical results alone. Fair Trade is important to them because it is based on principles of fairness, reciprocity and justice.

- They are concerned about environmental issues and the tension between consumption and sustainability

Dedicated Fair Trade consumers are passionate about Fair Trade and want to see it evolve to its fullest potential. Many of them are committed to a holistic view of sustainability that looks at beyond pure environmentalism to the overall health of 
human society and the future of its relationship with the planet. For them, Fair Trade is one positive way to move toward a better future.

- They are concerned about the co-option of the Fair Trade 'image' by mainstream business as a method of corporate green-washing. Moore (2003, p. 14) identifies the key challenge for Fair Trade in the future as "the ability to "stick together", to work to clear definitions and standards, agree and implement a strategy on mainstreaming while maintaining the purity of the concept, and its ability to campaign effectively to minimise the potential subversion, dilution or redefinition". Dedicated Fair Trade consumers agree with him. Participants highlighted the importance of retaining and further strengthening the credibility of Fair Trade labeling via stronger marketing campaigns and a high level of transparency regarding certification processes.

Participants identified that building strong, trustworthy brands will probably be a key factor in preventing the Fair Trade movement from going anaemic. Nicholls (p. I4) supports this idea, suggesting that "one strategic approach to increasing the Fair Trade market share is to develop some strong brands within it." In New Zealand, brands like Peoples Coffee and Trade Aid, whose entire identity and mission are tied to Fair Trade, continue to engender the trust of dedicated ethical consumers and, to them, are synonymous with 'Fair Trade' in New Zealand. 


\section{Research Question 2:}

Could these beliefs or perspectives translate into opportunities for Fair Trade organizations and developing country producers?

- Participants' testimonies indicate that Fair Trade provides a way of reducing social distance between consumers in the north and producers in the south.

Fair Trade has the potential to bring the stories and concerns of small farmers more prominently into development discourse by building their capacity to access and disseminate information, and by utilising this information strategically in Fair Trade marketing campaigns. In this sense, Fair Trade organisations and businesses become storytellers and partners with producers.

\section{- Fair Trade is a useful tool for promoting and developing global citizenship among northern consumers.}

Fair Trade has played an important part in the conscientization of western consumers by combining practical outcomes with a thought-provoking mission statement. This fact has led dedicated Fair Trade consumers to conclude that Fair Trade marketing has the potential to not only grow its Fair Trade's market share, but to function as a catalyst in the development of 'Global Citizenship' and a more globally and ethicallyminded society. John Pilger and Vandana Shiva argue that biased global media spread a "monoculture of the mind", establishing and enforcing their own status quo, while discouraging beliefs and behaviors that do not suit the activities of these corporations. According to my research participants, Fair Trade may be a useful too for sabotaging this brainwashing process and stimulating consumers to re-evaluate their beliefs about consumption and trade, and the world in general. Fair Trade is empowering rather than depressing, a useful first step intellectually and practically towards Global Citizenship. 
- Fair Trade would be less confusing to consumers if a more strategic, cohesive Fair Trade marketing campaign and branding effort was developed

According to my research participants, brands like Trade Aid are pioneers for Fair Trade in New Zealand, and they could represent the future of Fair Trade. Their branding is tight and to the point, and they are easily distinguishable from other businesses who operate in similar markets. They are a business that see Fair Trade as their bottom line. They connect the consumer with the producer in meaningful and creative ways, as many participants personally testified. They are forward thinking, and they conduct business with integrity and commitment to Fair Trade principles, navigating easily around both certified and non-certified forms of ethical trade.

- The participants are aware of the 'big picture' issues of Trade Justice, and do not regard Fairtrade labeling as a long-term solution

Dedicated Fair Trade consumers seem to keep a healthy tension between strong ethical principles and a sense of pragmatism. They see the subversive Fairtrade labeling movement is a necessary interim 'band-aid' that can both support modest development in the south whilst educating northern consumers on the wider injustices in world trade. While Fair Trade may only be a band-aid for small farmers, but it seems to be doing some much needed healing. In the meantime its consumers in the west are waking up to the need for institutional brain surgery, domestically and internationally. 


\section{Recommendations and Implications for}

\section{Development}

\section{Be cautious and strategic about the way Fair trade goes mainstream}

If it is to retain the support of 'people of principle', Fair Trade must take the time to define itself, to make it clear how it stands apart. If it deals with corporations and big business, it must be on Fair Trade's terms, not the other way around. It is only with an unequivocal commitment to integrity, transparency and accountability that Fair Trade will grow with its identity intact.

Do not allow growth opportunities to dilute Fair Trade's ethical principles As Fair Trade grows, the risks involved in going mainstream need to be strategically mitigated. One way to do this would be to strengthen key Fair Trade brands (like Trade Aid, but also infant Fair Trade businesses as well) through tighter and more cooperative marketing efforts. These businesses could work on joint publicity with organisations like Oxfam, events like Fair Trade Fortnight, and co-operative efforts to campaign against unethical corporate policies (like the Oxfam Campaign against Starbucks ownership of Ethiopian coffee brands, heavily supported by Trade Aid) and support other organizations to move toward more ethical trade. Further research is needed here on whether this is realistic, or whether it would be a logistical nightmare and contribute to further label fatigue.

\section{Explore ways that the Fair Trade labeling/certification system can reach a} greater number of the poorest producers

As the popularity of Fair Trade is accepted more and more by mainstream business and is given more opportunities to expand, it will need to maintain a tension between unwavering commitment to ethical principles on one hand, and flexibility and a willingness to adapt to changing world circumstances and consumer/producer realities on the other. Ethical consumers are concerned that the benefits of fair trade 
are still not filtering down to many of the poorest workers involved in the trading system. This will need to be addressed if Fair Trade is to engender the loyalty of a greater number of ethically-minded people. Luckily, it appears that Fair Trade has within itself the key to own survival; a willingness to adapt in whatever ways necessary to make way for what is just and necessary. Retaining this flexibility will be key to Fair Trade's ultimate survival.

\section{Explore more co-operative, strategic marketing methods that work to raise the awareness and credibility of Fair Trade among all New Zealand consumers}

One of the risks involved in going mainstream is the damage that misbehaved corporations that have adopted a Fairtrade product could do to Fair Trade's credibility. However, as long as strong Fair trade businesses and brands exist, it appears ethical people will be drawn to them and remain well-informed about the realities of trade injustices and the role Fair Trade plays in addressing those issues. Trade Aid has been operating in New Zealand for over 30 years, and is a pioneer with a great deal of experience that other organizations would do well to tap into. Based on the success of Trade Aid in recruiting both volunteers and customers to the cause of Trade Justice, I would recommend that other Fair Trade organizations learn from their successes and mistakes, and work together with Trade Aid and other successful Fair Trade brands to build greater brand loyalty in the face of competition from big businesses bent on green-washing. Exactly how that might look if far beyond the scope of this researcher, but key areas to work on would be:

- providing clear and concise information on trade issues

- verifying the authenticity of their Fair Trade brand

- empowering the consumer to feel like they can make a difference

\section{Explore new and old technologies that will more effectively reduce social distance through storytelling}


Ethical consumers seem hungry for a reduction in social distance between themselves and the citizens of the Majority world. To continue to reduce this distance, and to encourage greater solidarity (and in the future, with better technologies, even direct dialogue) between northern consumers and southern producers, everyone involved in the Fair Trade movement - from umbrella organisations like FLO to small businesses and activist groups - need to further explore the exciting potential of storytelling. By sufficiently reducing social distance, stories can ultimately intertwine to such a degree that both producer and consumer are empowered enough to shape the next chapter of their story together. The ability of the producers to contribute to and shape this storytelling is essential, and will no doubt be assisted by access to technologies made available by the capacity-building aspect of the Fair Trade premium and producer/consumer relationship. This is why it is so crucial to keep the 'band-aid versus brain surgery' issue in a healthy tension. Fair trade businesses in New Zealand may again want to look effective storytellers such as People's Coffee, whose Cafes are decorated with posters of producers and their stories. Utilising both new and old technologies, new and more interactive methods of storytelling might be found that enable the stories of producer and consumer to be brought closer together to truly facilitate the development of a healthy global village.

\section{Walk hand-in-hand with the sustainability movement}

As Fair Trade continues to grow, it will need to walk closely with the sustainability movement and other grassroots movements in the coming years if it is to retain the support of its existing dedicated consumer base. Climate Change is now accepted as a huge issue that is already affecting the citizens of the Majority world through dangerous weather patterns, droughts and floods. As such, the Minority world are now seeing sustainability as a key component of any development efforts. Fair Trade can continue to play a key role in International Development by paying close attention to the ideas being birthed globally and by contributing both philosophically and practically to the sustainability conversation. This will also be key factor in 
engendering the support of those consumers who are awakening to realities of globalisation and their place in an increasingly connected global society, for whom the issue of sustainability will be key. As Fair trade businesses plan for future growth, they particularly may want to identify new sources of growth outside the supermarkets (which were identified by participants as highly unsustainable), or even develop their own alternative systems of retail.

\section{Utilise Fair Trade more fully as a tool for developing Global Citizens}

As Margaret Mead one famously said,

"Never doubt that a small group of thoughtful, committed citizens

can change the world. Indeed, it is the only thing that ever has"

It will be 'global citizens', in the north and south, who will effect major change and deal with the macro issues. These citizens need to be informed, and my research indicates that Fair Trade is a key player in this process. A key objective therefore for anyone involved in the Fair Trade movement must be to 'reproduce themselves'. Fair Trade organizations should keep in mind this key point when they develop marketing and business strategies. They should also work collaboratively and strategically with other NGOs like Oxfam to further the 'conscientization' (as Paulo Freire would put it) of the global citizenry. 


\section{Final Words}

This research paper is but a small window into the world of the ethical/Fair Trade consumer. It has only scratched the surface of what is potentially a rich source of inspiration and ideas concerning the Fair Trade movement, and Trade Justice and Development in general. While this exploratory study has not yielded the kind of concrete quantitative data that many development practioners might find useful, it has delved into the more anthropological level, looking at Fair Trade as a culture and a movement that has spread in an organic manner throughout New Zealand and the world. Since it is inevitably these same supporters/consumers who will continue to give Fair Trade it's momentum into the future, their ideas and beliefs invaluable to anyone interested in the phenomenon of Fair Trade and where it may be going. 


\section{Bibliography}

Ayglon, C., 1999. 'Consumer adoption of a new product launch'. Internal report. Oxford: Oxfam trading. (unpublished)

Agrofair, 2004. 'The Co-op in Switzerland goes for 100\% Fair Trade bananas and Agrofair'. Press release, $2^{\text {nd }}$ February, sourced from www.fairtradefruit.com/Press Releases

Berndt, Colleen E. H., 2007. 'Does Fair Trade Coffee Help the Poor?'. Mercatus Centre, George Mason University.

Borregaard, Nicola \& Dufet, Anne, 2005. 'Challenging preconceptions about trade in sustainable products'. Sustainable Markets Discussion Paper, I. International Institute for Environment and Development, London.

Brazier, Chris. The No-Nonsense Guide to World History, Oxford: New Internationalist Publications, 200I.

Caldwell, Zarrin T., 'Fair Trade's Future: Scaling up without Selling Out?'. Perspectives, Issue 6, December 2005 (e-zine, available at http://us.oneworld.net)

Daly, Herman E. 1993. 'Problems with Free Trade: Neo-classical and Steady-State Perspectives'. Durwood Zaelke, Paul Orbuch and Robert F. Housman (eds.), Trade and Environment: Law, Economics and Policy (Washington DC : Island Press).

Demetriou, D. 2003. 'Consumers embrace ethical sales, costing firms $€ 2$.6bn a year'. Independent, 9 December, 7. 
EFTA, 200I. 'Fair trade in Europe 200I'. EFTA, Maastricht, Netherlands.

Flew, Anthony, 1993. 'Social Justice isn't'. Philosophical Notes 27. Libertarian Alliance, London.

FLO, 2005. Annual Report 2005/6. Sourced from www.fairtrade.net

FTAANZ, 2008. Financial report. Sourced from www.fairtrade.com.au

FLANZ, 2006. AGM Presentation, December 2006.

Hiscox, Michael J. 2007. 'Fair Trade as an Approach to Managing Globalisation'. Memo prepared for the conference on Europe and the Management of Globalisation, Princeton University, February 23, 2007.

Johnston, Josee, 200I. ‘Consuming Social Justice'. In Protest and Globalisation: Prospects for Transnational Solidarity, Goodman, James (ed.), Pluto Press: Sydney, $200 \mathrm{I}$.

Khor, Martin. 2000. 'Rethinking Liberalisation and Reshaping the WTO'. Presentation at the World Economic Forum, Davos, January $28^{\text {th }}, 2000$.

Lagos, Taso G., 2002. 'Global Citizenship-Towards a definition'. Published on Global Citizen Project Website (www.globalcitizenship.net), November, 2002.

Langland, Lise. 1998. 'On Communicating the complexity of a green message. Partl: The Max Havelaar case'. Greener Management International, Summer 98, Issue 22.

Littrell, Mary A. \& Dickson, Marsha A. 1998. 'Fair Trade Performance in a Competitive Market'. Clothing and Textiles Research Journal. 1998; 16: I76-I89. 
Martin, Sarah \& Hartley, Fiona, 2007. 'Oxfam Fair Trade Coffee Moderator Report'. Management Department, University of Canterbury.

Maseland, R. \& De Vaal, A. 2002. 'How Fair is Fair Trade?'. De Economist I50, pp25I272.

McCarthy, M. 2004. 'Fair Trade produce tempts the shoppers with a conscience as annual sales surge to $f 100 \mathrm{~m}$ '. Independent, I March, 5.

Moore, Geoff. 2004. The Fair Trade movement: Parameters, Issues and Future Research.

MORI, 1998. 'Citizens want tough environmental action now'. Summary of MORI polls and surveys.

Myers, Paul. 2007. 'All hands on deck: the future of Fair Trade'. Delivered to the Fair Trade Federation Conference, Washington DC June I, 2007.

Nicholls, Alex, 2005. 'Thriving in a hostile environment: Fairtrade's role as a Positive Market Mechanism for Disadvantaged Producers'. Said Business School, University of Oxford.

Oxfam, 2002. 'Rigged Rules and Double Standards'. Report for the 'Make Trade Fair Campaign.

Oxfam Campaigns, 1995. 'Fair Trade Action Update'. Oxfam internal newsletter. Oxford: Oxfam.

Pilger, John. 200I. 'The Crusaders'. New Internationalist, issue 333.

Plato. 'The Republic'. Penguin Classics; Rev/2nd Rp edition (September 30, 1955) 
Raynolds, L.T. 2000. 'Re-embedding Global Agriculture: The International Organic and Fair Trade Movements'. Agriculture and Human Values 17 (3): 297-309.

Raynolds, L.T., Murray, Douglas \& Heller, Andrew, 2006. 'Regulating sustainability in the coffee sector: a comparative analysis of third-party environmental and social certification initiatives'. Sociology Department, Colorado State University, USA.

Reid, Ben, 2005. 'Poverty Alleviation and Participatory Development in the Philippines'. Journal of Contemporary Asia, Vol. 35, pp29-52.

Redfern, Andy \& Snedker, Paul. 2002. 'Creating Market Opportunities for Small Enterprises - Experiences of the Fair Trade movement'. International Labour Organisation, Geneva.

Renard, M, 2003. 'Fair trade: quality, market and conventions'. Journal of Rural Studies, Volume 19, Number I, January 2003 , pp. 87-96(10).

Rice, P., \& Mclean, P., 1999. 'Sustainable Coffee at the crossroads'. Paper prepared for the Consumers Choice Council, Washington, DC.

Shaw, D., \& Clarke, I., 1999. 'Belief formation in ethical consumer groups: an exploratory study.' Marketing Intelligence and Planning, 17 (2 and 3).

Tallontire, Anne, 200I. 'Ethical Consumers and Ethical Trade: A review of current literature'. Policy Series I2. Natural Resources Institute, University of Greenwich.

Tiffen, P., \& Zadek, S., 1998. 'Dealing with and in the global economy: fairer trade in Latin America'. In J. Blauert and S. Zadek (eds), Mediating Sustainability: growing policy from the grass roots (pp. 163-188). West Hartford: Kumerian.

Trade Aid, 2005. 'Social Report, 2005'. 
TransFair USA, 200I.

Traidcraft, 1996. 'Social Accounts. 1995-1996'. Gateshead: Traidcraft.

UNDP, 1999. 'Globalisation with a Human face'. Human Development Report.

Vander, Weyer, 2005. 'Can free trade be fair trade?' New Statesman, Vol I34, Issue 4729, February $8^{\text {th }} 2005$.

Wilkinson, John. 2006. 'Fair Trade moves centre stage'. Working Paper 3. The Edelstein Centre for Social Research.

Wilson, Tim, 2006. 'Fair-trade coffee only brews more poverty'. Australian Financial Review, August 12, 2006.

Young, Graham. 2003. 'Fair Trade's influential past and the challenges of its future'. Report for the conference Fair Trade, an asset for development. An International Dialogue, delivered May $28^{\text {th }}, 2003$.

\section{Online references:}

Website I:

http://www.co-intelligence.org/l-powerofstory.html

Accessed I I/I0/2007

Website 2: http://www.scribblingwomen.org/newsletter/summer99/carson.htm Scribbling Women, Volume I Number 2, Summer 1999

Accessed I I/10/2007 
Website 3:

http://www.internetworldstats.com/stats.htm

Accessed I I/10/2007

Website 4:

http://www.blackpig.co.uk/brand-charity.php

Accessed 26/10/2007

Website 5:

http://marketing.about.com/cs/glossaryofterms///bldef_imc.htm

Accessed 26/10/2007

Website 6:

http://www.climatecounts.org/

Accessed 26/ I I/2007

Website 7:

http://kansasgrownfood.com/Beyond_Organic.html

Accessed 25/01/08

Website 8:

http://www.dolphinblue.com/pg-Forum-Moral-Consumption-Robert-Jensen.html Accessed 25/0I/08

Website 9:

http://www.fairtrade.net/impact_areas.html

Accessed 27/0I/08

Website 10:

http://ecomall.com/greenshopping/perid2.htm

Accessed 27/01/08 
Website II:

http://www.peoplescoffee.co.nz/images/galleries/cc_fairtrade.pdf

Accessed 28/0I/08

Website 12:

http://news.bbc.co.uk/ //hi/business/43 18882.stm

Accessed 29/0I/08

Website 13:

http://news.bbc.co.uk/2/hi/business//8446I8.stm

Accessed 29/01/08

Website 14:

http://observer.guardian.co.uk/foodmonthly/story/0,, I / I5290,00.html

Accessed 30/01/08

Website 15:

http://www.organicconsumers.org/articles/article_4738.cfm

Accessed 30/0I/08

Website 16:

http://www.foodqualitynews.com/news/ng.asp?n=82545\&m=I FQNI I 5\&c=oollhhqbcz powep

Accessed 3I/0I/08

Website 17

http:// www.newint.org/features/2006/I I/0 I/fairtrade/

Accessed 4/02/08

Website 18 
http://www.sofiatopia.org/equiaeon/clearings.htm

Accessed 4/02/07

Website 19

http://www.fao.org/participation//english_web_new/content_en/history.html accessed 12/03/08

Website 20

http://www.guardian.co.uk/uk/2002/jul/07/research.waste

accessed 23/04/08

Website 21

http://www.ipa.org.au/files/news_I203.html

accessed 23/04/08

Website 22

http://www.ifat.org

accessed I5/05/07

Website 23

http://www.fairtrade.net

accessed 23/07/07

Website 24

http://www.transfair.ca/tfc/glance.html

accessed 20/04/08

Website 25

http://www.blackpig.co.uk/brand-charity.php

accessed I5/06/07 
Website 26

http://www.fairtrade.com.au/FLO/FLANZ

accessed 19/04/08 


\section{Appendix I}

\section{Fairtrade labelling system}

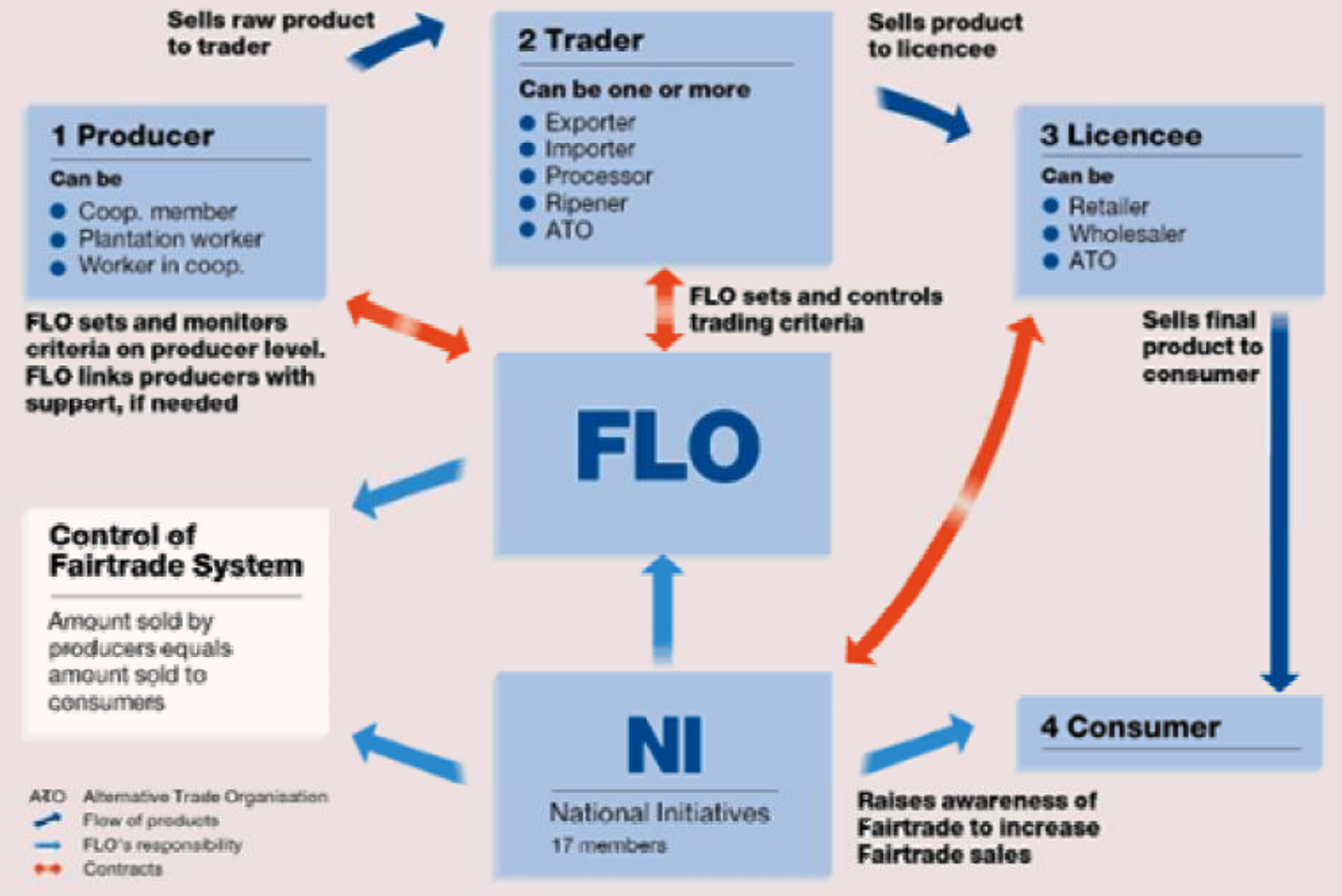

\section{Source:}

FLANZ AGM Presentation, 2006 


\section{Appendix 2}

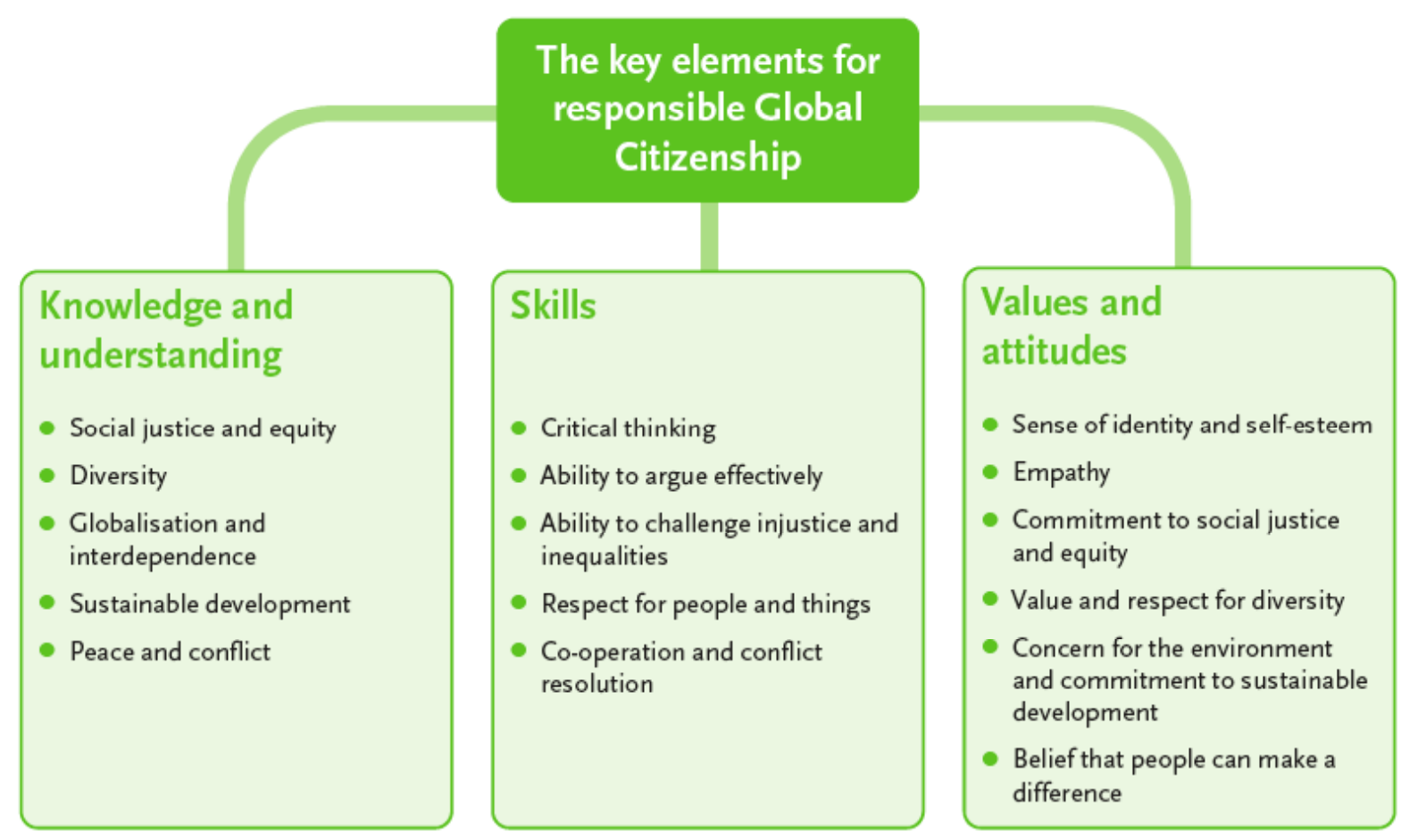

\section{Source:}

Oxfam, Education for Global Citizenship: A guide for schools, 2006, p.2. 


\section{Appendix 3}

\section{Transcript I}

$25^{\text {th }}$ june 2007

Focus Group participants: I- 4

R: Welcome everyone, thanks for coming. What does Fair Trade mean to you?

Participant I: I always say that Fair Trade is trade based on respect, and it puts people in the picture, people first, rather than a made in china tab or something, it actually puts people in the picture.

Participant 2: For me it's like a system within the capitalist system that corrects a byproduct of the capitalist system by prioritising people and sustainability, but still using capitalist-based models and trading systems

R: So working within the system, or alongside it, or..?

Participant 2: Yeah, correcting the system, but still within the system

Participant 3: Yeah, its sort of like constructing ethical norms in society, so its making ethics and justice and fairness into a norm rather than, if you look at realist and capitalist approaches, its very non-human, so it really puts a human quality to trade and relations, not just between people but between countries and things that are abstract. 
Participant 4: I didn't think about this till recently, when I was trying to talk to some teenagers about poverty, and they were saying "what's the point in helping poor people?", because they could see all these problems... I listened, and they came up with this big problem with development which is lack of real dialogue, and us helping by throwing money at people, and many Fair Traders are based in that dialogue and based in that partnership. It's not perfect, but it's a lot more based in dialogue than other stuff. Fair trade is about two communities having a fair relationship first, before having... people complain about the prices being really low and living conditions are hard, but if your getting the relationship right and based on long term respect for each other, that's what I like about it, because it takes away that superiority. Well.. it should.. it doesn't always.

R: So the relationship itself is actually an end in itself, not just he means to practically provide people with a higher source of income?

Participant 4: Yeah because you're not telling people what to do, your saying "hey, lets build a relationship, and trade together." It's still got a long way to go. I've been working with church groups who are trying to respond to poverty in the world, in ways that don't perpetuate problems, that don't perpetuate inequalities, and I think Fair Trade, basing itself in relationship, is quite good at that.

R: Do you think Fair Trade is in danger of perpetuating inequalities?

Participant 4: Yeah, I worry, there's always that balance. Its within the capitalist system, but it's a hard balance to make sure that its .. I mean, who's calling the shots, or should people really be growing coffee or chocolate in the first place? But at least it's trying, because if we get rid of Fair Trade because we find out its not, at least we can keep that relationship base there. If we make Fair Trade about that, that its about the relationship, then whatever it turns into, it'll be good. 
R: Because there are people all across the spectrum of Fair Trade ideals. Its been criticised for not being strict enough, not doing enough, then some criticising it for being too strict, preventing some people from getting in on the scene. It seems like there's lot of different visions for what Fair Trade could be or do. Its interesting that you guys have brought it right back down to the basics, that is a relationship.. that seems to be important to you. Why is the human aspect of Fair Trade so important to you guys? Why is it important to you to put a human face on a product?

Participant I: yeah, that's what I stared saying, that's the first thing that comes to mind for me. Its important to me on an ethical level, its important to me to know the people who are producing products that l'm buying, and that the way that they're produced is done in an ethical and sustainable way.. and that's related to my own belief system. It's intrinsically linked up to my own beliefs, what's important to me.

\section{R: Do you identify yourself as an ethical person?}

Participant I: Depending on what ethical means, but yeah... I think I do. I have quite strong ethics.. others might say that I don't, because I don't adhere to a particular belief system or whatever.

R: You spoke about your belief system before. Everyone has things they hold to be true about the world... do you see yourself as having a belief system, or is it mainly a head thing or?

Participant I: I think it's a bit of everything, it's a bit of head, reading about things, learning about what's out there, academic reading, going to university, studying, the intellectual side, and its also a bit of life experience, getting out into the world, seeing what's happening in other countries, different situations.. its also a bit of heart, its what feels good to me in my heart. It's a combination of all three. I think that's why Fair Trade fits, it fits on all those levels for me. I agree with Participant 4, its not a solution in itself its not perfect. But it's knocked in, it's a 
challenge, its challenging the traditional capitalist system, while it works within it.. that's all important to me, challenging the status quo rather than just going along. No system is ever going to be perfect, we can never create the perfect Fair Trade system, but if your always challenging the way things are, that's development.

R: How do you guys come to encounter the Fair Trade movement?

Participant I: For me it was Trade Aid, I really liked the shop. I went it there, it went from there really.

Participant 2: For me it was when I got an opportunity to work in Mexico as an ecologist. And I also worked with some farmers on a project there buying Fair Trade coffee directly from growers in mexico. I got interested in what Fair Trade is and about, I visited some growers in mexico, and that's how I found out about it.

Participant 3: I actually found out about it through university, it was quite recent, in the past year. I was taking an aid and development class in International Relations, and my lecturer invited some growers from Kuaapa Coco in Ghana, and they came and gave a talk, and it just really touched me at a very deep level. I wasn't expecting any logic behind Fair Trade, it made so much sense to me. From then I started volunteering at Trade Aid, finding out more about it, I wrote two papers on it.. and l've been interested in it ever since. It's something I want to keep pursuing, investigating, and helping the area grow.

Participant 4: I got into Fair Trade because some friends of mine, who were teaching me a lot of stuff about development, took me into a Trade Aid shop and talked to me about it. l've spent some time in a developing country, and I'm still tormented by what to do and how to help. I asked a lady in Zambia "what do you think the international community should do to respond to what happens in Zambia?", and she said they should just get out, and leave us alone. Since then l've been really tormented by it, to find ways in which the international community can respond in a 
fair way that isn't what it was that she was reacting to. Cos it's really important that we do respond. So Fair Trade was a cool way to do that.

Participant 3: Its important not to go in and say "we're here to help you", but, "we're here to cooperate and work with you", so we not there to instil our western values and say "this is what you should do, you have to join our international trading system".. it's going in and seeing what the producers need and want for their own societies, and cooperating with them.

Participant 2: I think that's an area that does need a lot of work in the future... there a lots of communities in which the current Fair Trade model isn't suitable, they have a low capacity and they are geographically isolated communities, its not even possible for them to get Fair Trade certified in the first place. For me I think that's got a lot to do with the rigidity of the model as it is now, and also how it needs to be decentralised to be more sensitive to local situations, and I think that's one way it may evolve in the future.

R: You mentioned you first encountered Fair Trade in Mexico? Out of the many people l've talked to about Fair Trade, not many have first encountered it from a producer perspective. How did it feel for you to learn about if from them? What was the impression they gave you about it improved their livelihoods?

Participant 2: For me it was quite difficult. It was cool connecting with people on a human level and hearing our mutual experiences. When we went there they had just built a really small church building with the proceeds from Fair Trade, but their lives were still really hard. It made me realise it's not a perfect solution but it does make a difference. A really important thing I learnt was, that even though materially their lives were still quite difficult, they were sticking with the Fair Trade system because it's a good model for fostering sustainability and solidarity within the community, and that's what a lot of producers often said, its not actually the extra income that's the 
real benefit, it's the structure that goes into the community... so that was really important for me.

R: Did you get any impression from them that they felt a connection with us, here in the countries where we consumed the things they grew?

Participant 2: Definitely. It was difficult because there was still a power dynamic that made me uncomfortable. They were really glad that people in the international community are aware that they're struggling and were trying to help them.

R: It good to know. You hear a lot of arguments against Fair Trade, but most of the time they are based on economic theory.

Participant 2: It really does make an difference on the ground.. why should economic theory override peoples wellbeing?

Participant I: Of course economic theory will be opposed to Fair Trade because that's exactly what Fair Trade is.. it's standing up against traditional economic theory. I think it's good that people challenge it from an economic perspective, it doesn't fit with their model. And we can say, no, its not.

Participant 2: It creates dialogue, about the potential for change.

Participant 3: There are arguments that Free Trade is Fair Trade, and through industrialisation and other processes its become something different.

R: It's a great idea, like communism, but because of human nature it fails.

Participant 3: Exactly, and the free market originated from an ideal. In the same way Fair Trade isn't an original idea, but an alternative. 
Participant I: It's not really Free Trade anymore, there's tariffs and taxes and all of these barriers and exceptions and rules that countries add to Free Trade. I think it's a bit hypocritical to say Fair Trade is bad because it restricts the market when Free Trade itself is not free.

R: I was reading an article challenging Fair Trade, arguing that there are massive overproductions of coffee which causes world-wide slumps in coffee prices. They were arguing that Fair Trade creates a commitment to coffee production, whereas farmers should in fact be exploring alternatives instead. But I actually read the FLO report, and part of the relationship between FLO and the farmers is to encourage them to use their premium to diversify, and provide support for them to do so.

Participant I: The other thing is, people say "why don't you just grow something else?" The thing is it's just not valuable to them, you can't sell cabbages the way you can sell coffee. I think coffee grows well in so many places where other things don't.

R: They've done studies to show the other crops that would grow well, but its the actual changeover that's so costly.. uprooting trees, growing new crops.

Participant 4: Yeah it takes something like 5 years just to grow a tree to the point where it will produce coffee.

Participant 2: In Guatemala, there are cooperatives who not only grow exportorientated products, but use the Fair Trade premium to work on subsistence farming as well, which I think is a great thing because it gives them food security, and reduces their reliance on exports. But I don't know how widespread that is.

Participant 4: I wonder what research has been done to see how much Fair Trade has increased the amount of coffee being grown. Because I get angry when people say by making the prices higher more people will grow coffee. It treats the producers like 
they're idiots. It's about creating opportunities. They need opportunities within the system to diversify.

R: Participant I was talking about her Fair Trade beliefs in the context of other ethical concerns. Do you guys feel a similar way? Do you care about other things as well, or are you just gung-ho about Fair Trade?

Participant 2: For me it's not a solution, its part of paradigm shift towards being more holistic about life. What l've struggled with a lot is combining environmentalism with development. A lot of the time the two are at odds with each other, and Fair Trade provides a way of integrating the two.

Participant 3: I don't see it as a panacea for alleviating poverty, its just part of the process of dealing with the world's ills. Firstly it's good because it acknowledges the human face behind the products we consume. It acknowledges that we do have a commodity fetishism in our western culture. That's what the media promotes. Fair Trade is changing the motivation behind what we buy and why we buy things. It's encouraging people to start thinking about their own values and encouraging a new paradigm.

R: So not just encouraging a mindless 'ethical consumerism'. Does it play a role in people's awareness of the wider picture?

Participant I: Definitely. I almost get offended when people buy it but don't really know much about it, or don't seek to know more... like its some kind of brand or some in-thing to do. That almost offends me. I think the only solution is wider education, getting people to see the way that it fits. Which is why, rather than talking about Fair Trade, I like talking about trade justice. Shifting the words a bit so people know you're not just talking about a label. But I think that's a too-big-a step for some people. People I know who hadn't heard of Fair Trade till I told them about it would not even have an idea of the wider picture. They need little steps to get them there. 
Fair Trade provides that step, but it needs to be backed up by something further. A real concern I have about Fair Trade is that it will move into (and it already is) a marketing tool, something that will be used by companies to make more profits.

Participant 3: That's the danger of Fair Trade becoming more mainstream. So many multinational corporations are incorporating Fair Trade into their branding. At the same time its good because its moving Fair Trade into more popular thinking, but its not a solution to overcoming the way we consumes, making people think "I can solve the worlds problems by buying more stuff".

Participant 4: A key thing I find in Fair Trade is how it links with the environmental aspects of consumption by getting people to recognising the story of what the product is. There's power in that. Even if Fair Trade becomes mainstream, if your making people see that coffee comes form the ground, from peoples sweat., it comes from real things, not just imaginary supermarket packets. I think there's a powerful thing in that, getting people to change how they consume anything. There's environmental and ethical aspects to all that. Personally I still find it difficult to get a lot of this stuff. I find it difficult to change my own consumption patters. But l'm recognising where stuff is coming from, and what it takes to create that thing. If Fair Trade can teach people that, and then the movement dies, I think you've achieved heaps. Because you're informing people. People still don't know that coffee grows on trees. That's a key thing, getting people to see the reality of what they're drinking.

R: Do you think the Fair Trade movement could do more than its doing right now to raise peoples awareness of whats going in the world?

Participant I: Fair Trade movement? Who do you mean?

R: I guess I'm encompassing both Fair Trade organizations and businesses involved. 
Participant 3: There are many divergences within the Fair Trade movement itself, just like any other movement. I think for the Fair Trade movement to move forward then we have to incorporate other movements that are ongoing, other revolutionary movements, like sustainability, environmental concerns etc.

Participant I: I think that's kind of happening with sustainability. It's in every newspaper, every magazine, and you do see links being made to Fair Trade, sustainable products etc. I do think there are ways the Fair Trade movement could link into in terms of equality, social justice movements, even health. Again, it depends on who in the Fair Trade movement is calling the shots. Obviously retailers have their own interests, and organizations and NGO have a different focus.

R: That almost seems to be the key issue in terms of peoples awareness and perceptions of Fair Trade.. at the end of the day, you get the Fair Trade product from a retailer. The bottom line is profit for a business. At the end of the day when you buy your Fair Trade coffee, unless you really push for the information, you won't necessarily get it.

Participant I: And then there's people like Oxfam who I feel can do an information overload. My experience with them has been that they produce tons of pretty pamphlets, whereas perhaps they should do more workshops, like they did at university. I saw real change and eyes opened there.

R: There are a lot of players in the Fair Trade game, and no one person has a single claim it. Even in labelling there are differences. Revive's coffee blend isn't completely certified, but some of the beans are. So how do you respond to situations like that? Do you boycott the coffee, or is it ok because it still does some good, or?..

Participant I: Yeah, its still worth taking that step.. it's one step more than other coffee shops or roasters might take. 
R: As a practical issue for roasters, especially a place like Wellington where there are a lot of discerning coffee drinkers, roasters are concerned with balanced coffee blends. There is a relatively limited range of Fair Trade certified beans, so that's a problem. Some of them still care about it. Have you seen this (flo logo) before? What does it mean to you? What do you think of?

Participant I: A person. The world. Creating a connection.

Participant 3: Balance, yin-yang.

R: What does it mean, what does it tell you about the product?

Participant 2: Well, I was actually thinking about FLOs certification of a Nestle product.. it brings up questions for me.

Participant 4: Trade aid rejected the Scarborough fair chocolate because they don't include Fair Trade sugar in their chocolate. I think of commodities as well. The majority of Trade Aid stuff can't be certified (handicrafts).

R: How important is that logo to you?

Participant 2: I think in terms of marketing and consumer accountability, its good to standardise and have a label so people can recognise it.

Participant 4: I like the design, I think its cool. But we altered it for our social justice group on campus.. we added more people. Because its not about just one person.

R: So this logo, or the lack of it, does it affect your purchasing decisions? What you do or don't buy? 
Participant I: If its there as an option, there aren't many places you see it in New Zealand.

R: Do you trust it? Does it represent any certainties?

Participant I: Depends what it's on. If it's on a Trade Aid product, yes. But if it's on a scarborough fair product, not so much. I'm a bit sceptical.

Participant 3: It does lend its credibility to a number of products. But if you were really interested in what you were buying you'd do some research on it.

Participant 2: That's why it's good to have a logo that people can recognise, because most consumers wouldn't go to those lengths to do the research. They wanna be in and out of the supermarket, so if they spot something visible that helps them out.

R: Have you guys seen other ethical labels?

Participant 4: Yeah, transfair.

Participant I: There's quite a few out of NZ. I was in Australia and I saw a lot of them. I thought, 'wow, look at all these'. Then I wondered if it was real, or fake. So I think there's a lot of value in having a unified label that people can recognise.

$\mathrm{R}$ : So in NZ theres less variety than overseas?

Participant I: Yes.

R: So less danger perhaps of label fatigue?

All: Yep. 
R: Just looking quickly at marketing. Have you guys heard of the sick-baby/well-baby messages? (Explains)

(shows well-baby message from amnesty, contrasts with sick-baby message from amnesty)

(shows Fair Trade flyers)

Participant I: I like the cover alternative trade, rather than Fair Trade.

Participant 4: I like this one with the dirty hand, its raw, its real, its not about emotions. A lot of these (unicef flyers) are pretty sensationalised. Relating the extremes.

Participant 2: I don't think these are emotive because of the way they're presented. I think they're emotive because of your reaction to them. That's just reality, how you feel about it is different.

Participant 4: I think I'm talking more about the text... What it's trying to tell you. It's trying to manipulate that reality, trying to create a certain impression.

(shows different unicef flyers)

Participant 3: I think it's just a case of how they've utilised a sense of urgency in the imagery, and the 'immediateness' of it.

Participant 2: I don't think portraying the reality of poverty is unethical... it's the manipulation through guilt that's not really constructive. It alienates a lot of people by making them feel fatalistic about what they can do. Its important to have both.. to portray the harshness of reality, and the solutions.

R: Looking at the Fair Trade flyers we've got here, how do you guys feel about those? 
Participant 2: That one (with the big grin) is a little biased I feel, because it seems to be saying "hey, everyone who is involved in Fair Trade is really happy", when that's just not true. Whereas this one (with neutral face) is a bit more realistic.

Participant 4: The hand in the dirt is more like raw reality... you have to look further into it, rather than reacting instantly.

Participant 3: The dirt one is looking more at the aesthetics of the industry, turning against it, using something more organically beautiful.

Participant 4: Yeah, makes you think.

Participant 3: Yeah, definitely more blunt. You know what they're going to say, you don't have to look at the words before you know what they're going to say.

R: Maybe they're intended for different purposes? The smile flyer is a smaller, postcard, whereas the dirt flyer is a tri-fold with lots more information.

Participant I: That's it.. photos are used for quick recognition for what the message/product is. Other pictures can be used to draw you in.

Participant 4: The organic one is more about your reality, not imposing a reality on you.

Participant I: It would be interesting to see who picked up each of these... what demographics. I think they're designed at different people.

R: I actually found a cool video. It's a UK campaign for Fair Trade fortnight.. using World of Warcraft. 
BREAK in recording at 1999

R: Do you have a preference in where you buy Fair Trade stuff from?

Participant 2: I think if I was out in town l'd just go to the nearest place for coffee.

Participant 3: I avoid Starbucks. They've opened a new one on Courtney place. l'd rather go to local cafes.

R: It's different in the US where people drink a lot of filter coffee, and Starbucks now brew Fair Trade filter coffee in their stores. Would you guys ever go to Starbucks.

Everyone: No

Participant 4: Something I find difficult with Fair Trade is that l'm not a big coffee drinker... I don't buy much in town. There's not that much Fair Trade stuff I really want to buy. So it's weird for me to make it an integrated part of my life. Common Sense (the store) is good because it has a lot of ethical labels to choose from. I find that difficult with Fair Trade .. that everything that is Fair Trade isn't that useful to me. I drink more coffee now out of obligation to Fair Trade.. which is really strange!

Participant I: It's different in the working world.. people drink a LOT of coffee! We're lucky because we get peoples coffee at work. People go get espresso as well, throwing out hundreds of non-recyclable cups a day. I do have a coffee addiction, and it makes it easy to support Fair Trade, having People's coffee at work. If I need an espresso, my biggest consideration is the nature of the café, rather than Fair Trade coffee being served. Starbucks vs a local café... or a café with nice atmosphere, nice people, nice mugs (not disposable cups). Fair Trade isn't necessarily the deciding factor, though it is in the mix. 
R: Its interesting you say that, because some cafes will offer a you a discount if you bring your own mug

Participant I: And some won't at all, because of 'health reasons'

R: Both cafes that I know of that do offer such a discount don't offer Fair Trade coffee.

Participant I: Of I 2 cafes around my workplace, one offered Fair Trade espresso, and another offered Fair Trade pressed coffee. One offered a discount with a special mug. BP do the same thing, offering a big refill if you have their mug. I think it's a step in the right direction, environmentally.

Participant 2: We're doing the same thing at Uni. We've just ordered some re-usable mugs, and we're trying to get discounts from cafes on campus. A really good question was "what are the mugs made of, and where do they come from?" It's really hard to cover all your bases, you have to pick your battles.

R: What information sources influence your understanding of Fair Trade? Do you guys feel you have an ongoing learning process when it comes to Fair Trade?

Participant I: A range of sources for me. Going to talks, magazines, newspaper articles, internet, talking to people.

R: When you say internet, do you mean Fair Trade websites?

Participant I: yeah, websites for products, organizations, events. I rarely pick up those flyers actually. It's the same old stuff to me... its not marketed at me. I did pick it up once, at Trade Aid. That worked back then. 
Participant 4: I found them quite good. Working at Trade Aid you learn a lot as well. You learn about individual producers. I learned a lot from my classmate as well.

Participant 2: I spend all day on databases as well, learning about Fair Trade, so ....And Im going to samoa next month, to get a feel for a pacific producers perspective.. what the barriers are for getting certified for Fair Trade cocoa there.

R: The last thing I really want to talk about is where Fair Trade is going, and problems inherent in it at the moment, concerns, ideas for improvement etc

Participant I: We've talked about the labelling, and how it can be misleading, and how it can be used as a marketing tool rather than what it really is. I'm also concerned about environmental impacts of trade, and how we're trying to reduce our carbon emissions, yet trying to trade with developing countries at the same time, which means air freighting or shipping goods. That will be a big challenge for Fair Trade, to stay aligned with sustainability. Also, it needs to be fair for the consumer, and as it gets less fair for producers and more of a marketing tool, it also gets less fair for consumers.

Participant 2: The tension in the future is all those nuances for environmental sustainability and carbon emissions from freighting, and trying to integrate that with mainstreaming and growing the market. So there's a tension between the grassroots, really empowering people and making a difference, which is sometimes in conflict with widening the market. There's the marketing side and the development side, and sometimes they are at odds with each other.

Participant I: Yeah I think one of the big debates is "should Fair Trade be mainstream"? At the moment its not, but should it be mainstream in the market?

Participant 3: I think the biggest obstacle to ethical trade is the current international trading system. You can't get around it, and unless that changes there's no way that 
Fair Trade will make a long term or sustainable impact on developing countries. I suppose you can work from the grass roots level, but the effects are limited if it just stays there.

$R$ : It seems to be there are people, even within the development arena, with vastly different ideologies and perspectives. In Fair Trade there seems to be the tension between the perception of Fair Trade as a solution that could grow and perhaps even take on these big problems, and those who see it as a band aid or an interim solution.

Participant 2: For me I see it as an interim thing. If I had the choice between buying everything at Trade Aid, and not buying anything at all, I wouldn't buy anything at all. Because buying stuff in itself causes lots of problems even if it is Fair Trade. But yes, it is a vehicle into (?).. but its not a solution in itself.

R: Do you feel like Fair Trade makes enough of an effort to point its consumers towards the bigger picture?

Participant I: I think Trade Aid makes a really good effort. I think a lot of others don't. But there's a lot of use as having Fair Trade as a logo, because it does give people something tangible to get behind. Changing international trade rules is a bit difficult, whereas Fair Trade is a useful tool. I think Fair Trade has created a sense of community.. I feel part of a Fair Trade community, through people l've met and things I've done. Similar to a faith community who all believe in something. I think that's really important... it does unify people with a range of beliefs under one banner. Other than religion and the environmental movement, what else do we have? I think the Fair Trade logo is something useful to hold on to for now.

Participant 3: Although its not very tangible itself, the Fair Trade movement is making incremental steps from the community local level to the national, and eventually it will move to the global level.. that's the main goal ultimately. 
R: I wonder how many people in Fair Trade cities know that they're a Fair Trade town?

Participant 3: I think in certain cities a decent proportion of the people know. But a survey done in Bristol showed that a lot of people didn't know they were in a Fair Trade city.

R: That's part of the reason I brought this whole well-baby/sick baby thing up, because different marketing strategies appeal to different kinds of people, with various levels of awareness of issues. I wonder whether the Fair Trade is missing out on any demographics of people because we don't utilise the sick baby message? Positive messages don't always move or motivate some people. I wonder how many people investigate why trade is unfair?

Participant I: Without being too simplistic, I think the concept of Fair Trade is more difficult than some of these other issues. I think it's harder for people to go out and find out about trade.

Participant 2: On the other hand it is a lot more accessible than the starving baby. You can support Fair Trade if you have a couple of bucks. Say you get ten people who walk into Trade Aid because they like the stuff, that's an avenue into their consciousness. Whereas the sick baby goes straight into their consciousness.

Participant I: It does depend on what you want to do. If you want to donate money, say 30 dollars a month to one child and forget about it, then you can. But if you want to become more involved...

R: Some people have mentioned that the appeal of Fair Trade is that they can make a difference... its not fatalistic. 
Participant 2: It is empowering rather than depressing, and I think for me it's a way for people to feel like they can do something, and then think maybe there's a way they can do more.

R: Have you been to People's Coffee? One thing that caught my eye was a big poster of one of one of the producers.. don alfredo I think. It's very whimsical, very human, it tells his story. It seemed to me to be almost like a progression, an evolution in the marketing of Fair Trade.

Participant 2: I think its integrating marketing and education. Fair Trade does that quite well.

Participant I: The language on these flyers is interesting too. Choose Fair Trade, choose Fair Trade, switch to Fair Trade. I think what Participant 2 is saying about how the consumer has the power is not promoted as much. I think the power of that isn't tapped into as much as it could be. Every individual has the power, markets only thrive because people decide what is popular. If everyone chose to boycott something, that company would go under. There is so much power in your choice, in your decisions. I wonder if that could be more powerfully portrayed. They did this one a few years ago, and it was a poster, and it said "you had the power". A lot of people have said "why are you promoting consumerism?", but what its really doing is using your consumer power.

Participant 4: Not buy, change. You're gonna buy anyway.

Participant 2: It's similar to 'voting with your dollar'. That's like empowerment and consumerism at the same time.

Participant I: I think this concept of conscious consumerism is something that Fair Trade should push more for. But conscious consumerism is such jargon. 


\section{Transcript 2}

$2^{\text {nd }}$ July

Focus Group participants: 5 - I5

R: What does Fair Trade mean to you?

Participant 5: Equal price for goods, so people pay what its worth, but also supporting the community and dividends for the community

Participant 6: And on a general scale a Utopia, the idea that the world can be a just place, and that by doing something, by implementing Fair Trade, everybody's equal

Participant 7: Also a fair dividend of profit, not just for retailers, but also for the growers

Participant 8: I think it means there's hope as well, because the people who are growing the coffee beams can invest in schooling for their kids, investing back into the land, so there's hope for the future, and their not locked into downward spiralling prices.

Participant 9: To stop exploitation

Participant 10: transparency

Participant 7: When you say Fair Trade, does that definition differ from country to country? We all have different GDP levels.. what I pay for a Fair Trade product here would differ from what I would pay in Tokyo or London. Exactly who has the control of setting this target? Is it dependent on geographic location? 
Participant I I: There are Fair Trade standards... you pay for it, and once you have that label you are certified Fair Trade. And it pays above the living wage... enough to make a profit, above the subsistence farming level.

Participant 10: It doesn't seem fair to me.. it seems fairer. Saying its fair is a bit of a rip-off.

Participant 6: It can almost seem quite scary, like a kind of marketing ploy.. You oFair Tradeen don't know what its about as a consumer, you just buy it because it makes you feel good.

Participant 8: There are some Fair Trade brands/labels, like FLO, you know you can trust, because you know people pay for that certification. You know that the mark-up on goods is going to be huge anyway, so you are paying a huge market, but there's a small benefit to the producer for sure.

Participant 6: But say you have no idea about markets or trade, and you don't know that there are people working in sweatshops in china, then you wouldn't really have any idea what Fair Trade means.

Participant I I: It's like carbon neutral, no one really knows what that means, but they think it's a good thing.

Participant 5: Its like an end goal.. an unattainable thing, like perfection, something to aim for. The prices might not be fair, but...

Participant 7: Its hard to measure it I suppose, but if there are people going out there to measure.

R: (explains FLO minimum prices) 
Participant 6: I don't think it fluctuates so much.. the world price moves around, the Fair Trade one stays much more stable.

R: You mentioned a utopia before... do you think that's what Fair Trade is aiming towatds?

Participant 6: Yeah, I guess its acknowledging that there are a lot of things in the world that aren't fair, and its trying to address that. I think that's one of the things that really appeals to people. None really likes the idea of exploitation, so if there's something you can do that doesn't require that much effort, then people are happy to do it. Particularly with Fair Trade campaigns you get lovely pictures of people in Africa working in fields and its always sunny...

Participant II: And smiling babies, and stories, always stories and how someone's going to school now...

Participant 6: Yeah so you get these lovely images of what you're doing in the world, and I guess that's where the idea of a utopia comes from.

Participant 10: A question.. you know how there's a proportion of the profits going towards development ls that always the case, or does sometimes the profit go towards further production?

Participant 12: It varies.. in Costa Rica, the premium is used for housing the community, and also growing a coffee nursery. Because sometimes the farmers lose their crops, so this way they have a back-up, which they can also sell for a good price.

$\mathrm{R}$ : (explains the structure of a co-operative)

Participant 5: So the producers get to spend it on what they want. 
Participant 6: Have you seen Black Gold? The co-op in that film chose to build a school with their premium.

R: Have you guys heard arguments against Fair Trade?

Participant I I: Lots. The idea that its just a band aid. People buy Fair Trade coffee and say “oh, l'm saving the world, so I don't have to think about this anymore". But its not just coffee, its chocolate, it shoes, its clothes, pretty much everything we buy or use. So it narrows the focus down, so you stop thinking about the global picture and you just think about the few products you can buy that are Fair Trade. Its also such a small thing to be doing, and there's so much poverty, so much production in poor countries for rich countries. Some people argue that rather than being a step in the right direction, it's a step in the wrong direction, because the focus is in the wrong place, and you need to be to focusing on the world structures and politics that cause the problems in the first place. So why are people poor, and why do we think that we can have our shoes made by four-yr olds in sri lanka and it's not an issue? So instead of people about thw whole global picture, its focusing it on these small things.

Participant 10: The average consumer doesn't have time to address those realities..

Participant 6: It could become more widespread, I know in English supermarkets you can get all sorts of Fair Trade products, bananas...

Participant 13: But that raises all sorts of issues in itself, like why are bananas being grown as a monoculture then flown to England. I have quite a lot of conflicting thoughts about it.

Participant II: Yeah, but then it can use more energy to grow bananas in hot houses in England than to have them shipped over. 
Participant 13: But why do we need to grow them in the first place? I guess there are a lot of problems as consumer-based solutions to things ... seeing yourself as a consumer rather than as an active participant or citizen... implying that you can change things through what you buy, rather than doing anything more radical.

Participant II: And it keeps you in that idea that you're not a person, your a consumer, and that's your job to consume, you think "I can use up the worlds resources if I'm doing it in a good way". And coffee uses up so much water, which is such a scarce resource now, and as the population grows it will become even more scarce.

Participant 13: As long as I'm addicted to coffee l'll buy Fair Trade, but why should I have coffee anyway? It's a luxury, why should I be able to get it?

Participant 6: But given it's so hard to change people's behaviour on a mass scale, given that most people are market driven don't you think Fair Trade is a viable way out? You can see we need to address the bigger issues, but they are so complex, but most people can't solve all that much on a global political scale, so surely these smaller initiatives do push people.

Participant I I: I don't disagree, but I'm just saying people can feel disempowered...the way to change things is to make people feel more empowered.

Participant 5: Fair Trade is not mutually exclusive with environmental campaigns. With Fair Trade you can have people who are more empowered from getting off a subsistence lifestyle by diversifying... producing products that better suit the environment they live in. l'd like to see all trade become fair in the future. That way people wouldn't be sidelined by the main market, and people would have enough knowledge, education and money to address environmental problems. 
Participant 7: Coffee is a livelihood for people in south America, and they voluntarily enter into this trade agreement, fair or unfair, just to get some kind of income. So I think if we stop importing bananas to the UK or NZ.

Participant I3: I'm not suggesting that we stop importing things tomorrow.. I just think that the problem is deeper than just "buy everything Fair Trade and it will all be alright".

Participant 14: I hope people don't think that. Its just part of it.

Participant 8: I've started buying Fair Trade coffee now, but it is more expensive.

Participant 10: Coffee's come down now.. it started out too expensive and with a lack of variety.

Participant 14: Some people don't trust Fair Trade either. l've talked to a few people, and they think that most of the money doesn't grow to the growers themselves. They think its going to Fair Trade organizations, and not reaching out to those growing the coffee in the first place.

Participant 12: So they need to be informed of what's happening, like a breakdown of the purchase price and what goes where.

Participant 5: I know on the Fair Trade site they have a breakdown of the price that they pay to the producers. It is shocking, you think that $50 \%$ will go to the producer, but its actually about $5 \%$.. and you think how can that be, that it's Fair Trade? But it makes you think, what would normal trade be?

Participant 10: Fair Trade says that there's these evil corporations out there, and that they take all the money and the farmer gets nothing. You pay the same amount or more for the Fair Trade coffee, and the Fair Trade label says that they're cutting out 
all these evil middle-men, and delivering coffee straight to the consumer. It makes you ask, where's all that money going, if less than a $\$ 1.50$ is going to the farmer per pound. The main chunk is still being lost in the chain... who's taking that?

Participant 5: People buy Fair Trade knowing they are getting ripped off a little bit, but with the hope that in the future prices will drop.. like you said, the Fair Trade price has dropped because the market for it has got bigger, its gone more mainstream and it can compete more.

Participant 10: It's an easy way to participate. My mother gets excited about anything Fair Trade. At the high school she teaches at all the girls know about Fair Trade, and they all get one the internet to research it. Its producing awareness that there is a whole world out there that isn't fair, and that's gotta be a good thing.

Participant 6: I agree. I think its important to have something quite tangible that people can see.. they can see the coffee and the chocolate, the label and the picture. Its easy to say "people should get involved on a global scale and change politics", but that's actually quite complicated and difficult. You have to be quite resourceful as well, to find out who you're gonna contact, what kind of issues you're gonna investigate. I think the high school story is encouraging.

Participant 5: If you see Fair Trade in the supermarket, at least you'll think about it... like, why are people buying this, what does it mean? Even if you don't buy it because you can't afford it.

Participant 6: I think the availability makes quite a big difference... because if its there, next to the normal coffee, you'll say "maybe this time I will pay a bit more and try it".

Participant 10: And it's seen as cool, and it is. I ask cafes if they're fair trade.

Participant 12: Do you walk out if they're not? 
Participant 10: Depends if there's another one nearby. The guy up at uni says it's the way, the future. As long at it's not a scam, it's a good thing.

Participant I I: Esquires do.. they're a retailer. They charge a dollar extra for their coffee, even though they don't need to. They're making extra profit of the perception of altruism.

Participant 6: Do IFAT make a big profit?

R: Those kind of orgs are funded by the importers via their license fee.

Participant 5: So it's not the producers who are paying, but the middlemen?

R: That's right, it's about shortening the supply chain.

Participant II: I think they're pretty onto it people, really trying to make a difference.

R: Some cafes are more expensive, but some aren't.. like Peoples Coffee.

Participant 7: Something that really confused me was that Starbucks went Fairtrade in their coffee. But they didn't [as an organisation]!

Participant I I: A lot of its propaganda. They do have one genuine Fair Trade bean.

R: (explains starbucks situation)

Participant I I: Even in their pamphlets, their proganda never says they're Fair Trade, they say "oh look at us, and our happy farmers". Its bullshit! My friends think starbucks is fairtrade.. that's the perception. They spend a lot of money on making themselves seem like that. 
Participant 7: Its an example of how a company like starbucks can jump on the bandwagon of something like this.

Participant I I: Didn't L'oreal buy Body Shop? And l'oreal test products on animals. Its really interesting to see all the links between companies.. some 'clean' branded companies are linked to dirty parent orgs.

Participant 5: Unless you follow the business news really closely you can't know this stuff!

Participant 14: I found out recently that Fair Trade and Nestle are affiliated! New Zealand is terrible for not labelling on country of origin.

Participant 6: I guess Fair Trade provides a way of feeling like we're informed, even if it's not the whole story.

Participant I I: It is interesting though, I was talking some people at SAFE who have this big protest against proctor and gamble, because its pretty much it. There's Johnson and Johnson as well, but that's it.. they control everything. Its scary.

R: Some of you mentioned Fair Trade in the context of other ethical concerns..

Participant 14: There's the whole idea that Fair Trade and sustainability are different... but they need to come together at some point. It's not going to work otherwise. It's the same as organic and sustainable, which don't always go together. There's a new concept called 'beyond organic' which is about incorporating all these ideas. There are all these conflicting ideas that need to be combined into one.

Participant 13: Yeah, and supermarkets are so unsustainable, and go against any kind of decentralising and becoming more sustainable. In the UK they have a huge share of 
the Fair Trade market, and its not really the direction it should be going in. You can get organic food in supermarkets really easily, but they can't be part of the solution.

Participant 5: They have open refrigeration.

Participant 13: And they treat farmers in the UK really badly. They don't care about the details.

Participant I I: I think that's an argument 'beyond' Fair Trade.. it needs to take more into account.

Participant 5: I think part of Fair Trade is sustainability. There are organic products that are Fair Trade.

Participant 6: It's difficult as a consumer. People say 'eat organic', then people say 'don't' because its been shipped in from overseas, or Fair Trade and its come from far away. And you want a balanced diet to be healthy.

Participant I I: I think the perfect solution is to take that whole supermarket thing apart. A friend of mine did her PhD on supermarkets, and they are really bad for vegetable producers, because they can pay whatever they want for veges and you have to accept that.

Participant 5: There is an alternative.. vege markets and farmers markets.

Participant 13: Particularly here because supermarkets are so expensive.

R: (Reads out Fair Trade principles, including sustainability)

Participant 14: So the sustainability is particular to the farming methods, not to the shipping or packaging. So you can have Fair Trade coffee in a non-recyclable bag 
which has been flown here and has all these other attachments that aren't sustainable.

Participant II: And disposable cups. One of the things Oxfam is promoting now is to bring your own cups to a café.

Participant 12: They do that at a mount cook café and you get a dollar off. But I don't think they promote it enough.

Participant 14: I think BP was doing it two years ago too. They could start that on Cuba street.

Participant 6: That's one thing that shocked me about coming to NZ (from the Uk) is the amount of disposable cups people use, and lids!

Participant I I: Apparently per capita NZ produces more waste than the USA.

Participant 5: Is that industrial waste, or?

Participant II: Not sure. Plus, you cannot recycle some things in NZ, because we're not big enough to warrant the plants that recycle some things. However, you use up more water by recycling sometimes, so what do you do?

Participant 12: All offbeat originals stuff is disposable ... it shocking.

Participant I I: Do you have eco-store? They have potato starch bags that biodegrade.

R: There seems to be a theme of environmental concerns. Do you think Fair Trade should rise up to meet those to, or is that going too far? 
Participant 13: I feel like climate change will affect, and is already affecting, people in poor countries more than people in rich countries, so you need to see it as inextricably linked.

Participant 12: If everyone cooperated in their causes they'd probably make a lot more progress.

Participant 6: Also if you're going to change one thing, you might as well push for environmentally friendly criteria.

R: But if you add more criteria to getting Fair Trade certified, how is that going to affect producers and the Fair Trade market?

Participant 12: It would become unattainable for producers pretty quickly.

Participant 10: The new labelling is asking for travel miles.. if Fair Trade starts asking for that, its gonna cause huge issues.

Participant 5: It could become unattainable, and it could take away from the main Fair Trade message, which is paying a just price.

Participant 14: It's becoming popular for small businesses to promote themselves as carbon neutral, so why couldn't that be a part of Fair Trade business? I know local NZ businesses are starting to do that. Why couldn't that work?

Participant II: I think carbon trading is ridiculous, because you sell off carbon credits to rich countries, so its basically a license to pollute.

Participant 6: You can predict how much abatement and how much damage happens, and that's how they calculate carbon credits. It is an unfair system, but it will reduce carbon emissions in the long run. 
Participant I I: But it's not fair for smaller countries, because they don't get as many carbon credits and their costs are higher.

Participant 7: What's happening in Vanuatu at the moment is that they're stopping a certain amount of logging to get carbon credits. They then sell these credits to Canada and the USA, and foreign loggers come and take the forests, and the money goes to the community. So that's a way that if you actually do this in a restricted manner, you can gain short term benefits. But you can't keep selling that forest, its only short term.

Participant 12: It seems like reducing consumerism is the only thing that will really help.

Participant 5: I don't know if that will happen.

Participant I I: The point is capitalism is run by us. If people didn't buy stuff anymore, the market would collapse.

Participant 5: But that would never happen.

Participant II: But you'd need less money.

Participant 12: We wouldn't need money as much.

Participant 5: It would be cool if everyone had vege gardens or a little garden up the back.

Participant I4: It's a false idea that you need to keep growing the economy. Why does it need to keep growing? 
Participant 12: Needs don't change. I guess it comes down to what you need rather than what you want. All you need is clothing, shelter and food.

Participant 8: Capitalism tries to make you 'need' things that you actually just want.

Participant 5: In the past a lot of people only had needs, not wants.

Participant II: We had a really restrictive import policy before the 1980s.. there just wasn't stuff in the stores. Then Rogernomics came and we opened the doors to capitalism.

R: What l'm really interested in is hearing about what your foundational philosophies are.. what your ideals are for the world, your utopia.

Participant 10: Freedom of speech, and democracy in a well-informed society. I don't believe in democracy unless it's in a well-informed society. It's useless otherwise. I was in El-Salvador, when they had the 2003 elections. They're all brainwashed, they claim to have democracy, but it's pointless. The parties target particular towns, and snowball the towns with things like the free t-shirts and propaganda. They paint the streets the party colours, and people are paid to paint their shops.

Participant II: Don't they say that democracy is the lesser of many evils?

Participant 12: I don't think politics helps a country that much. I don't think living in cities is beneficial.

Participant II: But there's too many people for everyone to have a quarter acre each! You'd push people into the ocean.

Participant 10: And cities are actually where movements often start from. In latin America the feminist movement started in the citizens, because you've got a mass of 
people, and that offers partial protection. If you speak up in a small community you could get your head chopped off, but in a city you have some friends. Same with the gay movement, started in the cities.

Participant II: People say we should go live in tribal societies but it seems like a big trade-off. People seem fine with the idea on a global scale, but then you begin to miss the things you have now, like travel.

Participant 10: Also how many women would enjoy living in these tribal societies?

Participant 5: It wouldn't necessarily be bad, It could be a matriarchal one!

R: The problem is using the word 'tribal' to encompass all traditional forms of society. Ancient tribal societies varied vastly in how they were organised and the way they treated women.

Participant 10: We've come forward in some respects.

Participant II: I think we romanticise the traditional life as well. Someone will say 'I wish I was a fisherman in cambodia', and I think 'no you don't!'

Participant 8: It is nice to have a simple lifestyle sometimes. But I couldn't do it forever.

R: Everyone has their own idea of what life is really about.

Participant II: Some philosophers say the ultimate aim in life is to want nothing, because all your needs are met. 
Participant 14: If you're working for what you need then you don't want anything else. Like with bartering. If I'm just working for my meal, I don't have any money to spend on extra things, so I just sustain myself.

Participant 7: The poor are trying to meet their needs though, and not their wants.

Participant II: Amartya Sen says that there is a standard of basic living, which is that everybody is able to develop their potential. People should have the opportunity in their society to develop their gifts. But in different societies, those contexts are different. Like in the western world, if you don't have a car then you might not have your basic needs met, whereas in a country where there are no cars it wouldn't be a problem. He says it's really hard to set a standard for basic living, because how do you know when anyone's needs are met?

Participant 5: Maybe you could try to measure happiness?

Participant II: Well that's what Bhutan tries to do, but they have huge human rights abuses!

R: Should the coffee farmers even try to get on the world market?

Participant 10: It depends.. you can't cut yourself off entirely, if you're gonna function. In NZ for example we have to import all our technology.

Participant 8: Yeah, we have 3 main exports apparently.. dairy, the all blacks, and sheep.

Participant II: There'd be no power if we couldn't import anything, because we have to import the generators. 
Participant 5: You could build things more durably.. these days products all seem to have built in obsolescence.

Participant 14: Maybe if we bought less, the quality of products would improve?

R: I was really interested to hear how you guys first heard about Fair Trade? What information sources taught you about Fair Trade?

Participant 12: Mostly people who support it. People who have come into my life in various ways.

Participant 5: Yeah, it's a social trend. People who influence you most lead you to it. But I didn't come to Fair Trade right away. I was more interested in environmental sustainability.

Participant 10: When was Fair Trade started?

R: (explains Mennonite history, ten thousand villages, Max havelaar etc)

Participant II: In Europe the farmers are so heavily subsidised, so there's all this wasted food.

Participant 5: Yeah l've seen fields in England of unharvested wheat, because they get paid to grow it but not to harvest it.

Participant I I: Because they can't sell enough of their grain for it to be economically viable.

$\mathrm{R}$ : (explains livestock subsidies in Europe of \$2) 
Participant 10: It's demoralising for the farmers. I stayed with a farmer in Wales, and he's paid to run a farm that wouldn't be viable here.

Participant I I: In Australia a really small number of farms make most of the food produced, and the rest are just subsidised by the government.

R: I'm aware its getting late, so we'll just try getting through some other topics. (shows them the FLO logo) What does this mean to you?

Participant 8: It's like a yin-yang.

Participant 5: A guy with his hand up, wanting justice, fairness.

Participant 7: What the name of the company?

Participant I I: Trade Aid.

R: No, it's the FLO logo.

Participant I I: Because that logo is on all the chocolate they sell at trade aid.

Participant 5: I thought IFAT were the ones who did certification?

Participant 7: I thought a guy from Costa Rica started it..

Participant 12: The guy who visited? No, it wasn't him.

Participant 5: There was another symbol a couple of years ago, people on a see-saw, but they replaced it with the FLO one.

Participant 12: What's the recent one, with two or three people on it? 
Participant 5: That's the IFAT logo.. the association that certify organizations as 'fair trade'.

R: The FLO label certifies products not organizations. That was the whole uproar with Nestle. They managed to get the FLO logo on one of their products. But the problem is they do all this other really dodgy stuff.

Participant 5: They got convicted of child labour for their cocoa farms on the ivory coast.

R: How do you feel about the fact that Nestle can get the FLO logo on one of their products?

Participant 12: Well, I don't think many businesses would find it viable to change all their products to Fair Trade.

R: What kind of businesses?

Participant 12: Especially clothing.. but any kind of business.

Participant 5: I think some businesses see it as an edge. A few people do it, to cover the ethical market to give themselves an edge.

Participant 8: Is the Fair Trade clothing still made in the same places?

Participant 6: Yup.

Participant 8: So is it better to buy that, or is it better to buy NZ made clothing? There's quite a few shops in Wellington who make clothes locally. 
R: Are you talking about the construction of the clothes? Or the cotton?

Participant 12: My t-shirt is made in Wellington, but the cotton is probably ripping someone off. But it's hard to find and certify Fair Trade cotton isn't it?

Participant 8: I know there's a local store, Frutti, where the clothes are designed and made locally, but l've never really thought about where the cotton come from.

Participant 5: I've seen some clothes with labels saying they are Fair Trade, but that was overseas.

Participant 14: So do people certify cotton and then have it shipped to people who make the tshirts and get that certified as well?

R: Well theoretically a sweatshop could import some Fair Trade cotton and then have little children make the tshirts on slave wages. Then the label could read "made with Fair Trade certified cotton". So labour standards are a different thing.

Participant 8: As soon as you know about Fair Trade, it feels like a sham to just buy Fair Trade coffee and not the chocolate and clothes as well. You feel guilty if you don't buy everything you can.

Participant 5: Often when it comes to clothes, I won't buy things I don't want to wear. Like no-sweat shoes, because they fall apart really quickly.

R: It also depends where they are made.. No-sweat shoes used to be made in Portugal. Now they are made in Indonesia.

Participant 12: Can the supply of product to make a Fair Trade lifestyle grow, and then the demand grow to meet it? Because it seems like neither of them are growing because the other isn't growing. 
Participant 10: Demand's growing, and I think supply as well. If you look at the range of coffee.

Participant I2: But clothes is way behind.

Participant 5: I think because some things are harder to make Fair Trade then others. People have gone for easy stuff and maybe it will get to a point where the hard stuff gets done.

Participant 8: I think transparency is growing about clothing. More documentaries are coming out, especially in Wellington with all the film festivals.

Participant 10: Yeah that awareness seems far more in your face now. People are more aware generally.

Participant I2: But people are still so uninformed.

Participant II: And what's the true story anyway? Sometimes its good in one way, but bad enough in another.

Participant 8: Yeah, and they'll make you aware of the issue, but then say "please keep buying our jeans, because we need our jobs”.

R: Do you think there's a risk of people being fatigued by the sheer complexity of the issues?

Participant 10: Definitely, that's why Fair Trade is so cool.

Participant 7: And there isn't a centralised way of knowing all the components of the system. You can see parts 'a, b and c' but not 'd, e and f'. 
Participant II: And never the whole picture.

Participant 5: We almost need a co-operative of people to get together to decide what to buy etc.

Participant 7: Also, with the Fair Trade clothing, it's not marketed to NZ. Bono's red label isn't available here.

Participant I I: That's the Nestle question. Buy buying anything from them, even a Fair Trade certified product, you are supporting them. Maybe we just need to stop buying stuff at all. But that's a really hard message, because what do you need, and what do you want?

Participant 8: I read a book about a group of people who decided not to buy anything new, except food. They bought everything else second-hand.

Participant 5: And there was a big backlash of people who said "that's so antiamerican!"

Participant II: Do you guys get ad-busters here? It's a great magazine but its expensive, because no-one will advertise in it.

Participant 12: We have it at the massey library but you can't issue it.

Participant II: (explains adbusters) I asks the question "why no we need all this stuff?"

And they have international 'buy nothing' day!

R: You brought up a good point earlier Participant II. We dictate capitalism. If more people buy Fair Trade, the market will grow. 
Participant 7: What sucks is that somewhere along the line you need to give up some of your ideals.

Participant 14: You already have.

Participant 5: We all have our wants, and we're unwilling to compromise them.

R: In terms of the future of Fair Trade.. where would you like Fair Trade to go in the future?

Participant 5: I'd like to see a greater range of Fair Trade products available, because of increasing demand, like clothes.. maybe timber? That's the direction l'd like to see it.. some kind of basic requirement that would allow more products to become more available.

R: How would you feel if FLO slightly lowered the standards involved so that more farmers could become part of fair trade?

Participant 5: I think it could be like wine labelling. In france for example they have a number of different layers: the best, second best etc, different classes. If it was common enough, like with wine, you could do it with Fair Trade labelling.. have different tiers.

R: Do you think that might confuse people?

Participant 5: Well it doesn't confuse the French with wine. In fact it's required. They go insane if they don't have it. It's in italy too. NZ has only just developed one.

Participant 14: How many are there? 
R: Five I think.

Participant 14: You could do a simplified version that wouldn't confuse people too much.

Participant 5: Because people are passionate about wine. If you have passion you can be discerning about what you buy.

Participant II: Do you think people would have the time though? Would they care?

Participant 5: I think another issue is how people prioritise their life at the moment. No ones volunteering anymore, they're working longer hours. So we have to try and reorganise how we work and play so we have more time to think about it.

Participant II: Don't you think then that we have to restructure everything? The way people think, the way we behave and structure our world?

Participant 5: I think it would happen anyway if you get more involved in Fair Trade. You start to think more about it. You start to think about how you work and play, what you do with your time, what they read about.

Participant 8: Back to the labelling thing, how would you create tiers or layers?

Participant 5: Well you could have the criteria for the $1^{\text {st }}$ tier, $2^{\text {nd }}$ tier, $3^{\text {rd }}$ tier. And farmers would say "we want to get $3^{\text {rd }}$ tier certification". The highest would be like the lowest, but with more rules or higher standards. Part of the label, so its not too much for consumer. Maybe red ribbon for first, blue for second, green for third.

R: That would probably be a design issue more than anything else.

Participant 8: Are there incentives to go up a tier as well? 
Participant 5: Yeah

Participant 8: They could do some research, to show that $2^{\text {nd }}$ tier sells more than $3^{\text {rd }}$ etc.

Participant 10: But consumers hate that complexity.. they go to a supermarket, they're often shagged. They want it as simple as possible.

Participant 14: Well if you had two or three, with the last one meeting all the sustainability as well, with carbon neutral etc, with the next one not quite meeting those but meeting agricultural ones.

R: If it's a slight modification of the existing logo than it would be less confusing.

Participant 10: People are tired just following Fair Trade and organics already.

Participant 5: I'm worried that Fair Trade organizations might get too much power. If a large market follows these labels, they could get corrupt. I know in Italy there are people who produce fake labels all the time.

Participant 14: That's why local certification is better. If we have NZ certification of international products that could work. l've heard the same thing about organics in China, they make fake stickers there. But if you have the certifying body in your own country, and they do the work, your in a different situation.

Participant 5: I'd like to see a Consumer Institute that could advise us on which products are ethically made.

Participant 8: I think the medals on wine are quite corrupt. Theres so many of them. 
Participant 10: Is Fair Trade moving through asia or India, or is it just in the west?

$\mathrm{R}$ : In terms or retail, or producer relationships?

Participant 10: Retail

Participant 5: Its definitely eurocentric.

Participant 10: When I was in latin America it felt like they were in future shock, just opening up to capitalism. And I thought, "shit, they're gonna make all the mistakes we've already made".

Participant 5: I think there are Fair Trade ideals in developing countries, its just not labelled fair trade. People buy stuff made locally and pay a good price for it because it supports the community. Because fair trade is traditional.

Participant 14: Yet what l've seen is tesco and other supermarkets opening in Taiwan, and people are flocking to them. It's becoming the most popular way to shop if you're reaching that income level.

Participant 10: We think we're bad. I helped set-up a refugee family, who had hardly any money, and all they wanted was an enormous plasma tv.

Participant I I: But that's the whole idea.. if you come from a really poor background, you just want that comfort. In post-soviet states, consumerism has just skyrocketed, because everyone can buy stuff now! What's happening is that people in our society are scared because we know that if everyone in the world consumed like we did, we'd be screwed, but we're screwed anyway, because of our consumerism. It sounds cynical, but we can't all do this. You can understand though why people want to buy things, if you've never had it. 
Participant 10: Totally. And its usually tied into things like status anxiety.

Participant II: Maybe its true that people need to make mistakes themselves before they learn.

Participant 8: Maybe there are no shortcuts to get countries through that development stage.

Participant I I: Its interesting, because Bhutan have started from the position that all their development needs to be sustainable. So they have hydro-power stations that they use to sell power to India, and that's pretty much their only income, because they are quite a poor country. They are still on a subsistence farming model. I think Bhutan is trying to be a utopia, but it's not a perfect country, there's lots human rights abuses, and not a lot of people go to school. But they're starting from that point of trying to be sustainable, so I think it will be interesting to see what happens there.

Participant 10: Yeah, Cuba will be an interesting one to watch too.

Participant I I: While Bhutan have an elected government now, they've had a ruler for a long time, and that's the whole idea of benign dictatorship. So it will be interesting to see what happens once democracy sets in.

Participant 8: My friend's Dad is an anti-corruption advisor, and he's about to go to Bhutan. They're limited to a thousand tourists a year in Bhutan, and you have to pay $\$ 200$ a day just to be there.

Participant II: And you can only move around on predetermined tourist routes.

Participant 8: There are ways around it though, if you go as a relation of a volunteer. 
Participant 10: It's the same in Cuba. There are two currencies, tourist and Cuban. And its illegal to stay with a Cuban. Cubans get all their food and stuff rationed. They're surviving, but not much else. Tourist money is the only way you can buy a luxury item. So for them to by nice shoes or anything they have to have the tourist money.

R: (explain how Fair Trade cuts out middlemen)

Participant 10: So why can't cafes in Wellington source their coffee directly? Why cant someone from a café here go to png and set up a contract with farmers? They could be super fair trade!

R: In New Zealand I think there are two licensed importers, and they import Fair Trade beans from all over. Then a coffee roastery will buy beans from them. That's why a lot of roasteries don't have Fair Trade coffees, because espresso is a blend of a few different beans. Peoples coffee set up a Fair Trade relationship with farmers in Costa Rica. But they don't import it themselves I think.

Participant 10: Is one of the problems too much coffee supply?

$R$ : That is one of the arguments against Fair Trade, overproduction of coffee. Some people say that Fair Trade encourages it. But FLO encourages farmers to diversify.

Participant 10: That's good. 